\title{
Starch Biosynthesis in the Developing Endosperms of Grasses and Cereals
}

\author{
Ian J. Tetlow * and Michael J. Emes \\ Department of Molecular and Cellular Biology, College of Biological Science, University of Guelph, \\ Guelph, ON N1G 2W1, Canada; memes@uoguelph.ca \\ * Correspondence: itetlow@uoguelph.ca; Tel.: +1-519-824-4120
}

Received: 31 October 2017; Accepted: 27 November 2017; Published: 1 December 2017

\begin{abstract}
The starch-rich endosperms of the Poaceae, which includes wild grasses and their domesticated descendents the cereals, have provided humankind and their livestock with the bulk of their daily calories since the dawn of civilization up to the present day. There are currently unprecedented pressures on global food supplies, largely resulting from population growth, loss of agricultural land that is linked to increased urbanization, and climate change. Since cereal yields essentially underpin world food and feed supply, it is critical that we understand the biological factors contributing to crop yields. In particular, it is important to understand the biochemical pathway that is involved in starch biosynthesis, since this pathway is the major yield determinant in the seeds of six out of the top seven crops grown worldwide. This review outlines the critical stages of growth and development of the endosperm tissue in the Poaceae, including discussion of carbon provision to the growing sink tissue. The main body of the review presents a current view of our understanding of storage starch biosynthesis, which occurs inside the amyloplasts of developing endosperms.
\end{abstract}

Keywords: amylopectin; amylose; cereals; debranching enzymes; endosperm; forage grasses; Poaceae; starch; starch synthase; starch branching enzyme

\section{Introduction}

The grasses can rightly be regarded as a cornerstone of human civilization. This large family (approximately 12,000 species) of monocotyledonous flowering plants is also called the Poaceae (or Gramineae). The Poaceae includes the cereals, which are domesticated grasses that are cultivated for consumption of their grain by humans and livestock, and the forage grasses, whose vegetative biomass provides a source of digestible energy and nutrients for domesticated ruminant animals. The Poaceae represent a highly successful group of land plants that have colonized all of the continents and climatic belts, with the exception of Antarctica. Growth of both domesticated and wild grasslands (savannah and prairie) therefore represent a significant proportion (up to 40\%) of the Earth's landmass.

Monocotyledonous (Monocot) seeds (more accurately termed caryopses) are particularly rich in starch, as opposed to many dicotyledonous (dicot) seeds that tend to store higher proportions of lipid, protein, and complex carbohydrates (hemicelluloses) in their cotyledons. It has been suggested that the reason for this difference is linked to ancient whole-genome duplication (WGD) events, occurring approximately 70 MYA, prior to the divergence of the Poaceae from within the monocotyledonous (monocot) lineage [1,2]. Following WGD, a dominant starch biosynthesis pathway in the endosperms of Poaceae resulted from preferential retention of starch biosynthetic genes and sub-functionalization of duplicated genes [3,4], and has been preserved throughout crop domestication from early Neolithic times when humans developed from herdsmen to cultivators. However, the major sub-divisions of the Poaceae were evolved by the end of the Pleistocene (Ice Age), probably from aquatic and semi-aquatic ancestors, and many of the subsequent wild forage grasses are ancestors 
of the modern cereals, originally growing in forest margins and deep shade [5,6]. Humans and their ancestors have utilized the starch-rich endosperms of the Poaceae long before the advent of agriculture [7,8]. Evidence from troglodyte caves in Africa suggests the processing of starches from ancestral relatives of sorghum (Sorghum bicolor L.) over 120,000 years ago [9,10]. In addition, studies of dental calculus from Neanderthal specimens from a wide geographical range show evidence of cooking and ingestion of wild grasses from the Triticeae tribe [11]. For a detailed review of the archaeological aspects of starch consumption by humans and their ancestors, see the mini-review by Copeland in this Special Issue. Subsequent domestication of selected grasses for their starch rich seeds as a source of calories has resulted in increased harvest index, with larger grain sizes and higher starch contents through the breeding of a number of physiological traits. Consequently, many modern cereal endosperms contain over 70\% starch [12]. Even cultivated non-cereals within the Poaceae, such as sugarcane (Saccharum officinarum L.), have seen a steady increase in the proportion of storage starch in the endosperm through domestication and plant breeding [13].

The importance of cereals in modern agriculture cannot be understated; the top three crops, in terms of harvested area and production are wheat (Triticum aestivum L.), rice (Oryza sativa L.), and maize (Zea mays L.), and cereals are represented in six out of the top seven crops currently grown worldwide [14]. Indeed, cereal yield has a major impact on world food supply. Starch-derived calories represent the major component of human daily caloric intake [15], and significant proportions of the major cereals that are being used in domestic livestock production (e.g., $38 \%$ in the case of maize). The high proportion of starch products that are consumed in the diet mean that this important source of calories has a major impact on human and animal health, in particular, starch quality characteristics, such as relative rates of digestibility influence blood sugar levels and lower gut health [15-18]. Moreover, a rapidly increasing world population (estimated to be 9.6 billion by 2050) and the loss of agricultural land to urban growth and climate change places unprecedented pressures on global food supplies. In particular, increased affluence in emerging world economies exacerbates these problems as meat consumption increases, placing extra demands on crop yields to meet demand for livestock production. Despite major increases in cereal yields resulting from the green revolution [19], based on current population growth, food production must increase $50 \%$ by 2030, and double by 2050 in order to meet the projected demands [20]. It is therefore imperative to understand the basis for, as well as limitations on, yield in the major crops (cereals), in order to produce improved, higher yielding/higher biomass crops and ensure greater food security.

This review outlines the process of starch biosynthesis occurring in grasses and cereals. Particular emphasis is placed on the economically important storage starches produced in the amyloplasts of developing seed endosperm, whose biosynthesis is distinct from that found in other tissues of the plant, and also from storage starch synthesis in dicot plants. Although the pathway of storage starch deposition in the endosperm is similar in all of the major cereals, carbon reserve storage and release in the source leaves differs widely between the different cereal groups. Leaf and stem carbon reserves play a major role in the growth and development of the plant, and prior to and during flowering, strategically localized carbohydrate reserves are critical in determining seed number and final yield ([21], and see recent review by MacNeill et al. [22]). Reserve deposition and release in these photosynthetic tissues mitigates embryo abortion and is therefore a major factor underpinning final grain yield $[23,24]$. Starch reserves also play a critical role in mitigating abiotic stress, which has important implications for crop productivity (see a recent review by Thalmann and Santelia [25]).

In addition, differences in the physiology and reproductive strategies exist between the major groups of Poaceae. The panicoid grasses (e.g., maize, sorghum and millet) generally conduct C4 photosynthesis and have a maize-like grain structure, whereas in the pooids (e.g., rice, wheat and barley), grain number and seed size are characteristic of source-limited plants [26].

The Poaceae are split into two lineages (or clades, see Figure 1). The PACMAD clade (representing the Panicoideae, Aristidoideae, Chloridoideae, Micrairoideae, Arundinoideae, and Danthonioideae), contains $>5700$ species including all of the extant C4 grasses, whilst the BEP clade (containing the 
Bambusoideae, Ehrhartoideae, and the species-rich Pooideae) is distributed mainly in temperate regions and contains exclusively C3 grasses [27]. However, for practical purposes, the Poaceae are often considered to comprise three sub-families, with the major cereals being represented in each [28]. The Panicoideae comprise the tropical and sub-tropical panicoid grasses, and include maize, sorghum, common millet (Panicum miliaceum L.), foxtail millet (Setaria italica L.), and pearl millet (Pennisetum glaucum L.). The Ehrhartoideae are represented by rice, and like the panicoid grasses, store starch and Suc in the leaves. The Pooideae subfamily includes the model plant Brachypodium (the first wild grass with a sequenced genome, [29]), as well as the grasses of the sub-family Festucoideae, such as wheat, barley (Hordeum vulgare L.), rye (Secale cereale L.), and oats (Avena sativa L.). The Festucoideae are temperate grasses, which also include the major forage grasses, such as perennial ryegrass (Lolium perenne L.), cocksfoot (Dactylis glomerata L.), and Italian ryegrass (Lolium multiflorum Lam. ssp. italicum), and predominantly store sucrose in their leaves as well as fructan, and starch is usually a minor $(<20 \%)$ leaf store [30-32]. Plants such as the dicot Arabidopsis or thale cress (Arabidopsis thaliana L.) predominantly store starch in their leaves and show strict control over its nocturnal degradation to ensure a steady supply of carbon to growing tissues until dawn [33]. However, cereal and forage grass leaves and stems, as described above, have variable types of carbon stores. For example, whilst temperate forage grasses store sucrose and fructan in their vegetative tissues (see above), some of the tropical and sub-tropical forage grasses such as the $\mathrm{C} 3$ arrowgrass (Echinolaena inflexa Chase) and the C4 molasses grass (Melinis minutiflora Beauv.), which is essential for cattle production on the savannahs of South America, store predominantly starch and sucrose in their leaves [34]. Sugarcane stores small quantities of starch in stems and leaves in addition to the high quantities of sucrose, and in this crop starch reserves are problematic in the subsequent processing of the cane sugar [35]. A number of studies indicate the non-linear rates of degradation and mobilization of these non-starch carbohydrate reserves during the night [36-40]. In the case of fructan-storing forage species such as darnel (Lolium temulentum L.), leaf starch synthesis appears to be limited at the expense of sucrose storage [41,42]. Non-linear rates of carbohydrate accumulation during daylight have also been noted for a number of temperate grass species [43-45], although this is not universal, as some, e.g., tall fescue (Festuca arundinacea Screb.), showed linear rates of storage carbohydrate accumulation during the day [46]. Not only do these leaf carbon stores play a major role in determining grain yield in cereals, but they also determine forage grass quality. Recent studies in other pasture plants such as white clover (Trifolium repens L.) point to the importance of leaf starch reserves in augmenting forage quality [47]. Details of leaf carbon metabolism of the various cereals and grasses and its relationship to plant growth is beyond the scope of this review, but it is an important consideration when examining the inter-relationships between sources (leaves, stems, and floral structures) and sinks (endosperm) in these different crops, and is covered elsewhere [48-50]. This is particularly important for some cereals of the world, such as sorghum and foxtail millet, which are grown as fodder (biomass) as well as for grain for human consumption [51].

In addition, differences in the physiology and reproductive strategies exist between the major groups of Poaceae. The panicoid grasses (e.g., maize, sorghum and millet) generally conduct C4 photosynthesis and have a maize-like grain structure, whereas in the pooids (e.g., rice, wheat and barley), grain number and seed size are characteristic of source-limited (C3) plants [26]. 


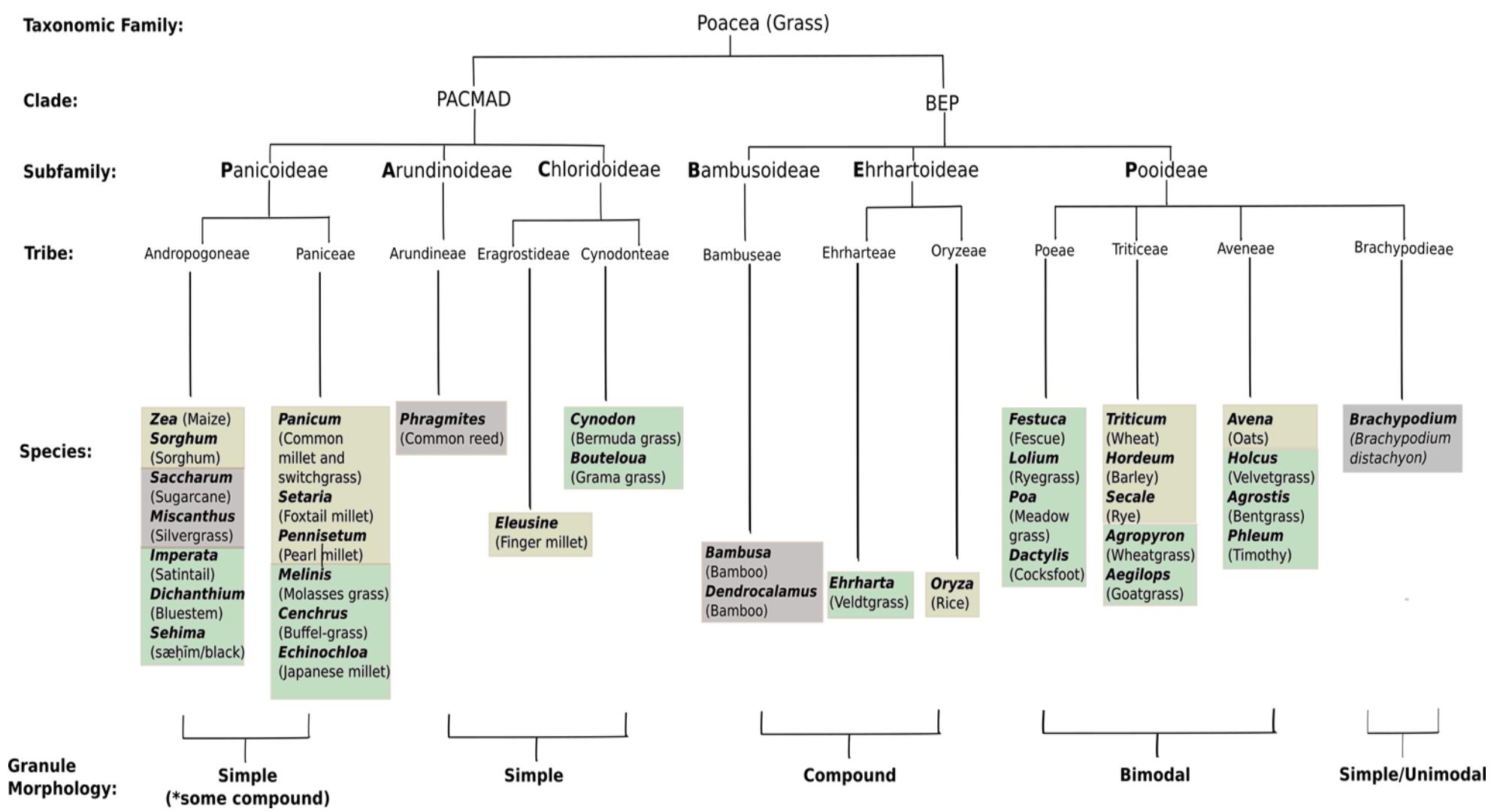

Figure 1. Major starch producing cereals of the world and their relationship to other agriculturally important Poaceae (grass) species. The grass family, clade, subfamilies, tribe, and species are shown on the top, and the starch granule morphology type in the endosperm on the bottom. The compound starch granule type in the endosperm is thought to represent the ancestral state. Grass species are grouped according to their major agronomic utility; yellow: cereals, green: forage grasses, brown: non-forage crops harvested for vegetative biomass, purple: model organisms. Note that many cereals are also grown as forage. Common names for respective major species members are given below in parentheses. * Some primitive Panicoid grasses, e.g., Sorghum italica, show compound granules (the presumptive ancestral starch granule morphology). PACMAD: clade representing the Panicoideae, Aristidoideae, Chloridoideae, Micrairoideae, Arundinoideae, and Danthonioideae; BEP: clade representing the Bambusoideae, Ehrhartoideae, and Pooideae. 


\section{Endosperm Development}

The endosperm tissue of cereals and grasses is a component of the grain (caryopsis), a single-seeded, monocarpellate, indehiscent fruit comprising two other genetically distinct tissues, the pericarp (a three-layered structure made up of epicarp, mesocarp, and endocarp, which is fused with the thin seed coat) and embryo. The formation of endosperm through the process of double fertilization is a defining feature of the angiosperms (flowering plants). Unlike many other plant species, the endosperm of the Poaceae is a persistent structure, and its biological role as a food source for the developing embryo of cereal grains make it one of the most valuable natural resources, providing much of the world's food. In modern wheat and barley cultivars, approximately half for the above ground dry matter is located in the grains at maturity, and, as plants mature post-anthesis, dry matter in above ground organs declines as grains gain mass [52,53]. A lower proportion of biomass is found in grains of wild grasses [54], indicating the increasing importance of the endosperm as a sink organ during crop domestication. A brief overview of endosperm development is presented, which is intended to put the process of starch storage deposition into the wider context of the physiology of the whole plant and its priorities and "decision making", with respect to carbon partitioning.

Endosperm development has been studied most extensively in the major cereals, most notably maize, which to a large extent has been used as a paradigm for endosperm development in the Poaceae $[55,56]$. Common elements of this crucial stage of seed development are outlined here, and the reader is referred to a number of reviews and articles detailing the species-specific differences between the major cereals, maize [56], rice [57], wheat [58], barley [59], sorghum [60], and wild forage grasses [61-63]. Endosperm development is characterized by three major cytological stages following double fertilization: syncytium (coenocyte) formation, cellularization, and differentiation. Immediately following fertilization the endosperm develops via a commonly observed mechanism, whereby the division of the primary endosperm nucleus, and subsequent divisions of daughter nuclei, is uncoupled from cytokinesis, resulting in a multi-nucleate cell with a central vacuole (the endosperm coenocyte or syncytium) at around two days after pollination (DAP). Newly synthesized anticlinal cell walls enclose peripheral nuclei in tube-like structures termed alveoli, which have an open periclinal face towards the central vacuole and increase surface area for transport of nutrients. It is at this point that cellularization begins, and continual alveolation occurs until the central vacuole is filled with cells (approximately 2.5-4 DAP in maize [64], see Figure 2). Following cellularization, around 4-5 DAP, regions of the developing endosperm differentiate into five cell types; the starchy endosperm, aleurone and sub-aleurone layers [65], basal endosperm transfer layer (BETL, or endospermal transfer cells), and the embryo surrounding region [56]. The BETL is a unique endosperm cell layer that is characterized by an increased basal membrane surface area (transfer cells), and plays a critical role in the provision of carbon from maternal to filial tissues for starch synthesis in the endosperm [66]. The endosperm then undergoes mitotic cell proliferation and endoreduplication from approximately 5-20 DAP, and it is at this stage that genes that are encoding the enzymes of starch biosynthesis are expressed and accumulation of starch and other storage compounds (e.g., storage proteins) occurs $[58,67,68]$. A number of studies in wheat and maize indicate that the rate and yield potential during the grain filling process correlate well with starch granule number in the endosperm, which in turn is directly related to endosperm cell number [69-72]. These observations underline the critically important stage of endosperm cellularization in determining seed viability and yield in the grasses and cereals. The period of alveolation and subsequent cellularization and differentiation is acutely susceptible to environmental stresses, as interruptions in water and sugar supply impede cell division and ultimately affect the grain size and final yield [73-75]. 

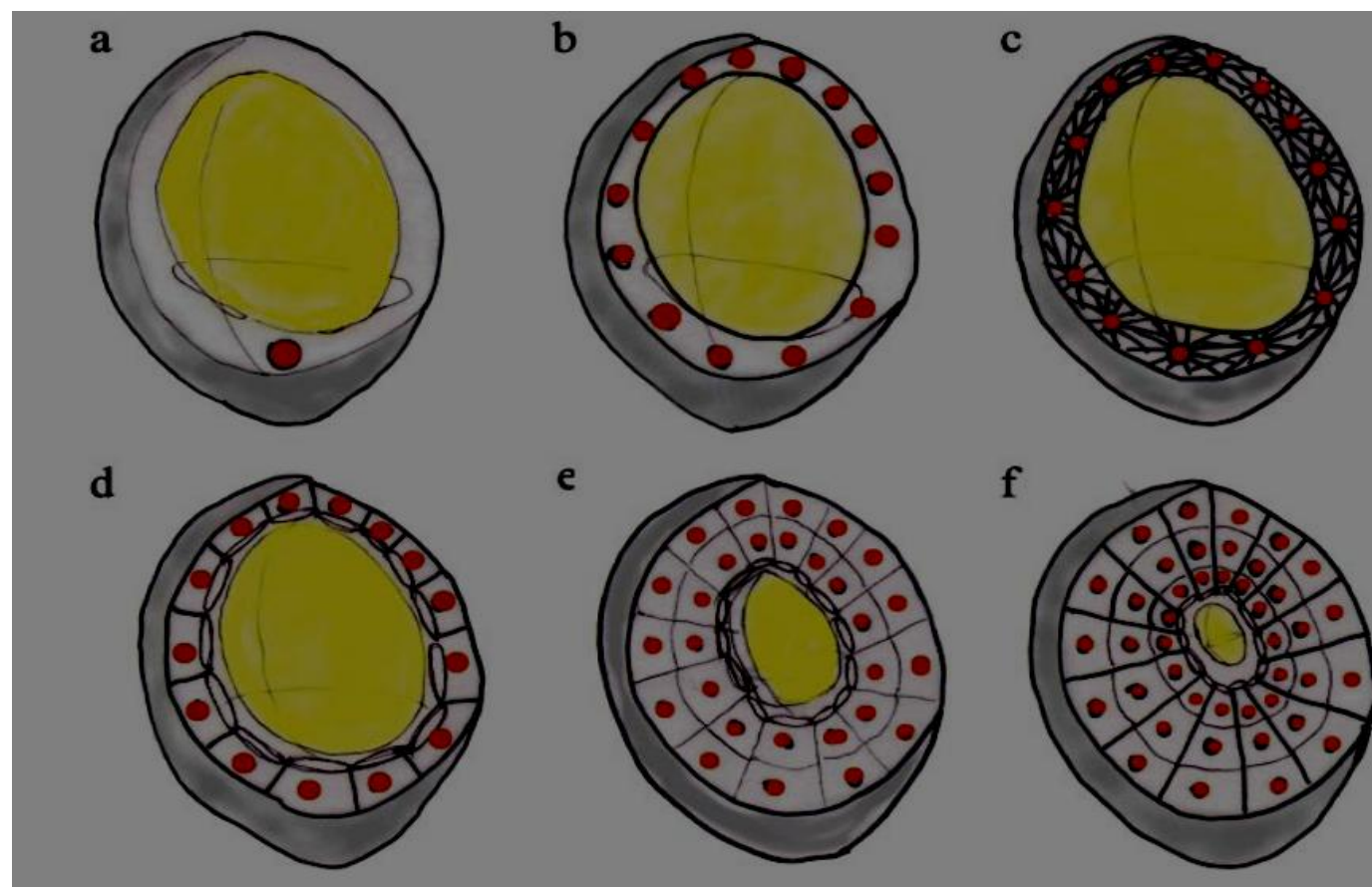

e

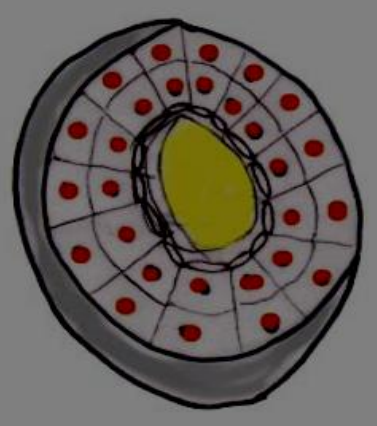

f

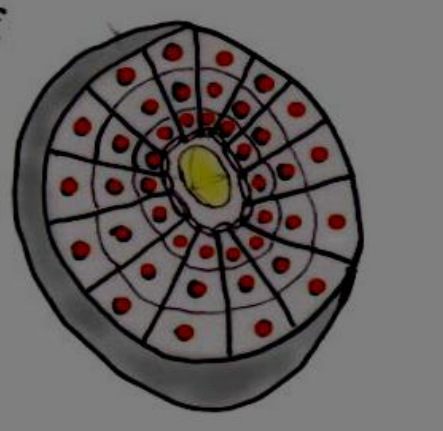

Figure 2. Diagrammatic representation of the cellularization process occurring in the developing endosperms of the Poaceae. (a) shows the fertilized triploid nucleus (orange) and central vacuole (yellow), (b), multinucleate cell with large central vacuole, (c), cellularization, formation of a radial microtubule system (RMS) emanating from the surface of endosperm nuclei, (d), cell wall formation; each nucleus is surrounded by a tube-like wall structure termed the alveolus, (e), continued growth of alveoli, and (f) mitotic division. Image adapted from reference [64].

During caryopsis growth and development the endosperm tissue becomes increasingly hypoxic. Oxygen micro-sensor measurements made within the grains of wheat [76], maize [77], barley [78], as well as seeds of dicots (see review by Radchuk and Borisjuk [79]) have established that hypoxia is the norm in these tissues. Although the outermost cells of the endosperm are partially oxygenated in smaller grains [80], in larger grains oxygen levels decline as tissues grow, and deep within the mature seed are in a state of near anoxia. Far from being a stress, deep hypoxia in the endosperm controls harmful oxidation, and helps to ensure longevity and viability of seeds [81-83]. In addition, the hypoxic environment within the developing endosperms of grasses and cereals dictates important aspects of sucrose metabolism (see Section 3 below), and in fact may be advantageous to the storage of starch biosynthesis and sink strength [84].

Later stages of endosperm development, following reserve deposition are characterized by desiccation and programmed cell death; in general in most cereals this occurs around 25 DAP, until maturity and harvest $[85,86]$. The phase of storage starch deposition within cereal and grass endosperms is the focus of the remainder of this review and is discussed below.

\section{Provision of Carbon to the Endosperm}

The endosperm cells, which begin to synthesize storage starch following the cell differentiation stage (see above), are heterotrophic, and therefore are dependent upon a supply of sucrose, ultimately derived from distant photosynthetic source tissues and transported in the phloem. The Poaceae, in common with the majority of herbaceous plant species load source-derived sucrose via an apoplastic route $[87,88]$, a mechanism that maintains high concentrations of sucrose in the phloem relative to the surrounding mesophyll cells, and is thought to facilitate high relative growth rates [89,90]. High sucrose contents in the endosperm are thought to act as a buffer against fluctuations in photosynthetic 
rate, and sucrose translocation to the developing endosperm (and its concentration in the tissue) is maintained throughout the diurnal cycle [91,92]. In grasses and cereals, the embryo and endosperm are physically separated from maternal tissues, and sucrose takes a mandatory apoplastic route through the cell wall prior to direct transport into sink cells of the endosperm via energy-dependent sucrose $/ \mathrm{H}^{+}$co-transporters. In some cases, sucrose is cleaved to glucose (Glc) and fructose by invertase (INV) prior to transport into the endosperm by hexose transporters (see [21] for a review). The site of phloem unloading in maize, and related crops, such as sorghum, is the pedicel and placento-chalaza [93]. In forage grasses and the Festucoid cereals, such as barley and wheat, it is the crease vein [94-96], and in rice, it is the vascular system on the ventral side of the ovary [97]. In the classic model that is proposed by Shannon $[93,98]$ for maize kernels, sucrose is cleaved at the phloem unloading zone (pedicel and BETL) by vacuolar and cell wall INVs. Hexoses are transported into the endosperm at the basal BETL membrane by SWEETs. Selection of hexose transporter (so called SWEET) genes has been shown to be a key feature of the domestication of modern maize from the wild grass ancestor teosinte [99]. This pathway operates in young (up to 8 DAP), abortion-sensitive, tissues in maize, and sorghum [100,101], with high Glc:sucrose ratios being associated with cell proliferation in the endosperm [61]. In developing maize endosperm, INV activity is maximal at 3-4 DAP, then declines [102]. The action of INV may be particularly advantageous in the early stages of endosperm development (cellularization and cell expansion) by providing enhanced turgor gradients (Glc and fructose, the products of INV, create lower solute potentials than those of sucrose synthase) for pressure-driven movement of sucrose in the phloem [89], enhanced water movement into sinks for cell expansion, and provision of respiratory substrates for various metabolic processes. In addition, INV may play an important role in tissue- and developmental-specific hexose sugar signaling, which regulate cell cycle and cell division pathways [103-105], and in certain dicots, such as Arabidopsis cytosolic INV, is the primary route by which carbon from sucrose is delivered to non-photosynthetic tissues [106].

At later stages of endosperm development hexoses, produced as a result of INV, are used to re-synthesize sucrose via sucrose phosphate synthase (SPS), and the sucrose is then subsequently cleaved by sucrose synthase (SuSy) into UDP-Glc and fructose. Ultimately, these products are used for the synthesis of ADP-Glc, the soluble precursor for starch biosynthesis [21,98]. In some species, such as barley and wheat, there is no evidence for an INV-mediated unloading process $[95,96]$. As the cereal endosperm develops from a tissue dominated by cell division and expansion to one of storage starch deposition, the role of SuSy in the provision of carbon precursors and determination of sink strength increases [107-109]. The switch from INV to SuSy-mediated sucrose metabolism (which is not confined to grasses and cereals, see [110,111]), may be an adaptation to the increasingly hypoxic environment prevailing within the growing sink tissue (see Section 2 above). Hypoxia is known to repress expression of INV [112] and up-regulate SuSy expression [113]. SuSy-dependent sucrose cleavage may reduce ATP costs within the hypoxic environment of the endosperm, as sucrose mobilization via INV requires ATP-dependent phosphorylation of two hexoses, as opposed to one with SuSy-dependent cleavage [114-117]. However, mutants of either INV or SuSy are still capable of starch accumulation $[109,118]$. Clearly, there is overlap between the different pathways of sucrose breakdown in the endosperm, highlighting the fact that our understanding of carbon provision for starch biosynthesis in storage organs remains unclear.

In grass and cereal endosperms, UDP-Glc pyrophosphorylase (UGPase) is highly active in metabolizing UDP-Glc to glucose 1-phosphate (Glc1P) for starch synthesis [119-121]. Formation of Glc1P (used in starch synthesis, see Section 4 below) from the UDP-Glc produced in the sucrose cleaving SuSy reaction requires UGPase, a step requiring inorganic pyrophosphate (PPi) $[119,122,123]$. Under low oxygen conditions in the endosperm, the limitations on ATP production may favour PPi-driven glycolysis by PPi-dependent phosphofructokinase $[104,114,124]$, as well as cytosolic reactions that are capable of generating ATP, such as pyruvate kinase $[125,126]$. It should be noted, however, that direct evidence for PPi-driven glycolysis in cereal endosperm is lacking. The demands 
for PPi within the endosperm in terms of driving ATP production from glycolysis, and Glc1P from UDP-Glc metabolism may be met and balanced by the reversible reaction catalysed by ADP-Glc pyrophosphorylase (AGPase), which produces PPi and ADP-Glc from Glc1P and ATP (see Figure 3). AGPase is uniquely localized in the cytosol in grasses and cereals, and it is a key enzyme of starch biosynthesis. Its provision of PPi for other cytosolic reactions (above) ensures that its catalytic activity favours ADP-Glc formation and essentially couples its activities to sucrose breakdown (see Section 4 below). In addition to the hypoxic conditions that are prevailing in the endosperm that appear to be conducive to starch synthesis, some aquatic members of the Poaceae, such as the common cattail or bulrush (Typha latifolia L.), and the common reed (Phragmites australis Cav.) produce large quantities ( $70 \%$ by weight) of storage starch in their submerged rhizomes $[127,128]$ under highly hypoxic conditions. Mutations in key steps in the provision of carbon for ADP-Glc formation outlined above, namely, miniature 1 (min1) for INV, shrunken 1 (sh1) for SuSy, and either shrunken 2 or brittle 2 (sh2 or bt2) for AGPase, underline the importance of cytosolic ADP-Glc as a precursor for storage starch synthesis in the endosperms of the Poaceae $[98,109,129,130]$.

Early stages of endosperm development in grasses and cereals are characterized by transient starch reserves in maternal tissues that are immediately surrounding the endosperm, such as the pedicel in maize and the pericarp layers in forge grasses and cereals. Studies in the major crops have shown that these reserves of starch (and other non-structural carbohydrates such as arabinoxylans and mixed-linkage $\beta$-glucans [131]) accumulate around the time of cellularization and differentiation. However, they are exhausted during the early stages of reserve starch deposition in the endosperm [21,132-134], and are therefore important in providing carbon at the early, critical stages of endosperm development.

In addition to the enzymes thata are involved in sink metabolism (above) and the starch biosynthetic enzymes discussed in the proceeding section, studies in rice and maize endosperms have revealed a number of proteins that are involved in controlling endosperm development and starch formation. Mutations in the so-called FLOURY ENDOSPERM (FLO) proteins in rice indicate that control of the process of starch synthesis is exerted at multiple locations in the endosperm. For example, FLO2 positively adjusts the expression level of starch synthesis-related genes via interaction with bHLHs transcription factors [135]. FLO4, encoding a pyruvate orthophosphate dikinase, was shown to regulate carbon partitioning between starch and lipid biosynthesis in the developing endosperm, aleurone, and scutellum tissues [136]. Other FLO proteins influence starch granule size and morphology, and are discussed in the sections below. A number of transcription factors have recently been identified as controllers of the starch biosynthetic pathway. Recent work in maize has shown that the endosperm-specific transcription factors opaque2 $(\mathrm{O} 2)$ and prolamine box binding factor (PBF) that are involved in regulating storage protein (zein) deposition in the endosperm, also regulate starch quantity through effects on gene expression of key starch biosynthetic genes [137]. In rice, a basic leucine zipper transcription factor (OsbZIP58) regulates the expression of some of the major genes involved in the starch biosynthetic pathway [138]. 


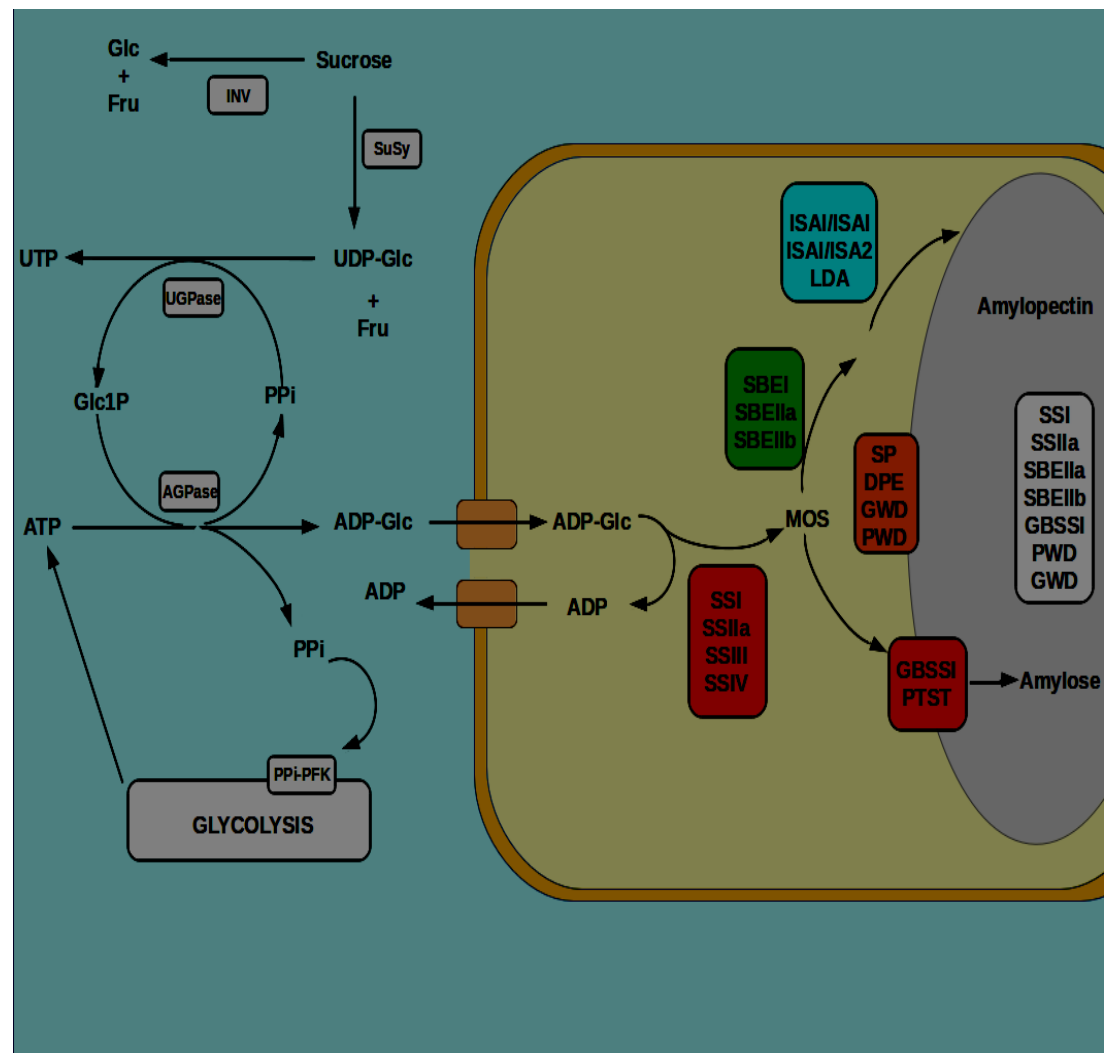

Figure 3. Outlines the starch biosynthetic pathway operating in the heterotrophic tissue of the developing endosperms of the Poaceae utilizing sucrose derived from photosynthetic tissues. Examination of this pathway reveals the major distinction of the pathway of storage starch synthesis in grasses and cereals is in the provision and delivery of the carbon precursor ADP-Glc. Cereals and grasses possess a cytosolic form of ADP-Glc pyrophosphorylase (AGPase) in addition to the plastidial isoform found in other tissues and plant species. ADP-Glc is imported to the amyloplast via counterexchange with ADP by the transport protein BT1. Inorganic pyrophosphate (PPi) consumption by UDP-Glc pyrophosphorylase (UGPase) and PPi-dependent phosphofructokinase (PFK), and generation of Glc1P (from UGPase) and ATP (glycolysis) favours formation ADP-Glc via the cytosolic AGPase reaction. Inside the amyloplast the major enzymatic reactions involved in starch synthesis are enclosed in boxes; red, starch synthases (SS); green, starch branching enzymes (SBE); and blue, debranching enzymes (DBE), including limit dextrinase (LDA). Enzyme activities whose precise role in the overall pathway is not clear are enclosed in an orange box; starch phosphorylase (SP), disproportionating enzyme (DPE), glucan water-dikinase (GWD), and phospho-glucan water-dikinase (PWD). Starch biosynthetic enzymes in the white box are isoforms found tightly associated with the starch granule (granule-bound proteins). All other enzymes in the cytosol are represented as white boxes. AGPase, ADP-Glc pyrophosphorylase; INV, invertase; SuSy, sucrose synthase; UGPase, UDP-Glc pyrophosphorylase.

\section{General Pathway of Starch Biosynthesis}

Starch is synthesized inside plastids of higher plants as a water-insoluble, osmotically inert, carbon store employed for both short-term storage (e.g., over a diurnal cycle in chloroplasts of photosynthetic tissues, such as leaves), or longer-term for the next generation (e.g., storage starch of seed endosperm amyloplasts). Starch is a polyglucan that is composed of linear $\alpha-(1 \rightarrow 4)$-linked glucans and $\alpha-(1 \rightarrow 6)$-linked branches, and is made up of two polymers, amylose, a near-linear molecule comprising approximately $25 \%$ of the granule in most plants, and amylopectin, which is highly branched [139]. The organized positioning and frequency of $\alpha-(1 \rightarrow 6)$-branch points in amylopectin contributes to the water-insolubility of starch granules. Starch granules show huge diversity in their 
size and morphology, characteristics that are often species and tissue dependent [139]. Details of starch structure and granule architecture are presented in a review by Bertoft in this Special Issue.

The basic pathway of starch synthesis occurring in plants involves the synthesis of a soluble precursor, followed by the coordinated reactions of $\alpha-(1 \rightarrow 4)$-linked glucan chain elongation, branching at $\alpha-(1 \rightarrow 6)$ positions, and debranching of specific branch linkages. Synthesis of the nucleotide diphosphate sugar precursor ADP-Glc from ATP and Glc1P is catalysed by AGPase. $\alpha-(1 \rightarrow 4)$-linked glucan chains are formed by ADP-Glc-dependent transferases, called starch synthases (SS), $\alpha-(1 \rightarrow 6)$-linked branch points introduced by starch branching enzymes (SBE), and debranching is catalysed by debranching enzymes (DBE) (see Figure 3). Each of the major enzyme classes that are mentioned above is divided into different subunits and isoforms, with some enzymes becoming physically associated with the growing starch granule (granule-associated proteins). In particular, the cereals and grasses are characterised by further sub-division of some enzymes into different tissue-specific isoforms, in some cases, with different sub-cellular compartmentalization (see [140]). Assignment of function for the various isoforms of the different enzyme classes in the pathway of starch synthesis has largely been through analysis of mutants. However, caution in the interpretation of such data should be exercised, since limited biochemical data is available for many enzymes, many isoforms of the different enzyme classes have overlapping catalytic activities on $\alpha$-glucan substrates, and many enzymes form heteromeric protein complexes (see below). Details of the operation of these enzymes in storage starch synthesis in the endosperm amyloplasts are discussed below. For details on starch formation and turnover in chloroplasts of source tissues the reader is directed to more general recent reviews of the starch metabolic pathway in plants [141,142].

\section{Starch Deposition in the Endosperm}

The starch biosynthetic pathway in endosperms of the cereals produces storage starch, which is the major caloric component of human and many livestock diets. The pathway by which this important commodity is produced is found in other members of the Poaceae and is distinct from other plant species, and also from the pathway of transient starch biosynthesis that is occurring in photosynthetic tissues of these plants. Much of our knowledge of this important biochemical pathway is derived from studies on economically important cereal crops (maize, wheat, barley, and rice), which represents a relatively small proportion of the Poaceae, and little by way of empirical data is available for wild and forage grasses. Indeed, the germplasm of ancestral cereals and forage grasses holds much promise for the future improvement of modern cereals with respect to important agronomic traits, such as resistance to biotic and abiotic stresses (see recent reviews: [143-145]). Therefore, although most of the work cited with regard to the starch biosynthetic pathway refers to modern cereals, it is reasonable to extrapolate these data to include the closely-related wild and forage grasses.

\subsection{AGPase: The First Committed Step in Starch Biosynthesis}

The AGPase reaction represents the first committed step of starch biosynthesis, and therefore plays a pivotal role in regulating carbon flux, from sucrose to starch, in the developing endosperm through the provision of ADP-Glc [146]. AGPase is a heterotetrameric enzyme made up of two large subunits (AGP-L) and two small subunits (AGP-S). In cereals, most of the endosperm AGPase (70-90\%) is extra-plastidial, located in the cytosol [147-150], and a minor portion is found in amyloplasts. Genetic studies in maize, rice, and barley have shown that the predominant cytosolic isoform of AGPase is responsible for controlling the flow of carbon into storage starch in the endosperm [150-153]. ADP-Glc that is produced in the cytosol is transported into the amyloplast for starch synthesis via an ADP-Glc/ADP antiporter (termed BT1) located in the plastid inner envelope membrane [154-156]. The presence of extra-plastidial AGPase is not confined to domesticated cereals, but seems to be a unique feature of the endosperms of the Poaceae. Cell fractionation and metabolite analyses have determined that the majority of AGPase in the barley subspecies Hordeum spontaneum L. (a progenitor of modern barley), wild barley (Hordeum murinum L.), wild oat (Avena fatua L.), and darnel was 
extra-plastidial [157]. It is argued that cytosolic AGPase, being coupled to sucrose breakdown via SuSy (see above Section 3, and Figure 3) allows for efficient starch synthesis when sucrose is plentiful, but confers metabolic flexibility, such that carbon is also available for other biochemical pathways when sucrose is limited $[119,157]$. The AGPase reaction is reversible (see Figure 3) and forward and reverse reactions are close to equilibrium. However, for starch formation to occur, the ADP-Glc-forming reaction is favoured by the removal of PPi. In the cytosol, ADP-Glc formation by cytosolic AGPase is probably driven by PPi-consuming reactions, such as UGPase and PPi-dependent phosphofructokinase (see Section 3 above), whilst plastidial formation of ADP-Glc is driven via cleavage of PPi by inorganic pyrophosphatase [158]. However, many other cytosolic reactions in addition to AGPase generate PPi, and high steady state levels of PPi have been measured in in the cytosol of barley endosperm [159]. Consequently, the exact mode of operation of a cytosolic AGPase under such conditions is still an open question. Plastidial isoforms of AGPase (in chloroplasts of the Poaceae and other plants, and in storage tissues of other plants) are subject to allosteric regulation by 3-phosphoglycerate (3-PGA, activator) and inorganic phosphate ( $\mathrm{Pi}$, inhibitor) [146], as well as redox modulation; activation occurring via reduction of an intermolecular disulphide bridge between the AGP-S subunits at conserved cysteine residues [160,161]. However, the major cytosolic AGPase in the endosperm of Poaceae is far less sensitive to allosteric modulation $[148,149,162,163]$ and lacks the cysteine residues that are required for reductive activation. A detailed review of the regulatory properties of AGPase and their exploitation for crop improvement can be found elsewhere [164,165].

Since starch synthesis in the endosperm drives sink strength (see Section 3 above), it is perhaps not surprising that AGPase has been the focus of much attention in attempts to increase cereal yields. Most efforts involved the over-expression of AGPase via seed-specific promoters in major cereals [166-171]. However, in all of the above cases, the cause of yield gains was unexpected; increased seed number (rather than seed size) through reduced ovule abortion, or increased biomass of maternal tissues. Such studies point to limitations in source strength, and underline the importance of carbon provision to the developing endosperm (see Section 3 above). Increases in seed weight through increased starch deposition have been achieved through the manipulation of regulatory properties [172-174] and structure: function relationships of the AGPase enzyme (for a review, see [165]).

\subsection{Elongation of $\alpha$-Chains by Starch Synthases}

Starch synthases (SS) belong to the glycosyltransferase family of enzymes and catalyze the transfer of a Glc residue derived from ADP-Glc onto the non-reducing end (C4) of an $\alpha-(1 \rightarrow 4)$-linked glucan primer [175]. The ADP that is released from this reaction is exported from the amyloplast in counter-exchange for cytosol-derived ADP-Glc via the BT1 transporter. At least five classes of SS are found in the developing endosperm, each with distinct catalytic properties with respect to substrate preferences and $\alpha$-glucan product that is formed [176]. The SSs share structural characteristics with each other, and other glycosyltransferases, e.g., glycogen synthases, including a highly conserved K-X-G-G-L motif in the C-terminal domain that is responsible for substrate binding [176-179]. Variation amongst the SS isoforms is found in the N-terminus upstream of the catalytic core, and varies in length from $2.2 \mathrm{kDa}$ in granule-bound starch synthase I to approximately $135 \mathrm{kDa}$ in maize SSIII [180]. The SS genes are generally split into two groups, the first being primarily involved in amylose synthesis (GBSSI) and are exclusively localized to the starch granule, and the second group (SSI to IV) found as soluble enzymes in the stroma, as well as the starch granule, whose role is confined to amylopectin biosynthesis.

\subsubsection{Granule Bound Starch Synthase I}

The amylose component of starch is synthesized by a single, specialized SS termed granule-bound starch synthase I (GBSSI) so named because of its exclusive localization within the granule matrix. GBSSI is encoded by the Waxy locus in cereals [181,182], functioning in the endosperm and pollen tissues, specifically to synthesize amylose [183]. GBSSI elongates amylose via the processive addition 
of Glc from ADP-Glc [184], leading to an essentially linear polymer of up to DP 6000 [185]. In addition to its role in amylose biosynthesis, GBSSI may also be responsible for the extension of long glucans (termed extra-long chains) of amylopectin [186]. Mutations in the Waxy locus leading to loss of GBSS activity results in amylose-free (Waxy) starches in a number of cereals [187-189], and in maize there is a clear relationship between Waxy gene dosage and GBSSI activity, and resulting amylose content of the storage starch $[190,191]$. Loss of amylose in cereal starch has, in some cases, slight effects on structural and physical properties of granules [192-194], yet other reports indicate no apparent structural effects [195-197]. Expression of GBSSI in cereals and their pre-domesticated ancestors is confined to the endosperm and other storage tissues, whereas a related isoform of GBSS (GBSSII), which is encoded by a separate gene, is responsible for amylose synthesis in leaves and photosynthetic tissues, which accumulate transient starch [198-200]. GBSSI is the most abundant granule-associated protein [201,202]. Recent studies in maize have shown that a transcription factor, termed ZmEREB94, regulates the expression of GBSSI, SSI (see below) and AGP-L [203]. In vitro studies with GBSSI from dicot sources indicate that the enzyme is active within an existing granule matrix, indeed, catalytic activity appears to be stimulated in the presence of high concentrations of crystalline amylopectin [204] and in the presence of malto-oligosaccharides (MOS) [205], which are probable substrates. The operation of GBSSI within the highly confined environment of the granule matrix is thought to account for the long, linear structure of amylose, since other starch biosynthetic enzymes (e.g., SBEs) may not have access to this substrate. GBSSI activity, and, ultimately, amylose content may also be affected by ADP-Glc availability, as the enzyme has a lower affinity for ADP-Glc than the soluble SSs [206]. A study in rice endosperm showed that GBSSI is able to form oligomers, and that oligomerization is promoted by increasing the physiological concentrations of ADP-Glc and post-translational protein phosphorylation [207]. Interestingly, other groups have noted the phosphorylation of GBSSI in the starch granules of maize endosperm [208]. Although the catalytic activity of GBSSI is solely responsible for constructing the amylose polymer, recent research by Seung et al. [209] has shown that the formation of amylose probably requires at least one other non-enzymatic protein. GBSSI does not appear to possess a starch binding domain, and interacts with a protein containing a carbohydrate-binding module (CBM48) via short coiled-coil domains on each interacting protein. The CBM48-containing protein, termed Protein Targeting To Starch (PTST), was first identified in Arabidopsis, but it appears to be present in all plant species, and directs GBSSI to the starch granule via its CBM48 domain [209]. Loss of PTST results in loss of GBSSI from the starch granule and no amylose, demonstrating that it is an essential component of amylose biosynthesis.

\subsubsection{Soluble Starch Synthases}

Three isoforms of SS (SSI, SSIIa, SSIII) are found in the amyloplast stroma, and are involved in amylopectin biosynthesis by elongating pre-formed $\alpha$-glucans of varying length (MOS) that are produced from the actions of other enzymes (e.g., other SSs, the actions of debranching enzymes, disproportionating enzyme, or starch phosphorylase; see below). Each of the three SSs has optimal chain lengths of substrate and products, but all share some overlap in these characteristics. The limited biochemical studies with cereal endosperms show that SSI and SSIII account for the majority of extractable and measurable catalytic activity of SS. Biochemical studies with SSI and genetic studies with ssI mutants from cereal endosperm indicate that this isoform is primarily responsible for the elongation of short glucan chains, utilizing $\alpha$-glucan chains of DP 6-7 and producing elongated products of DP 8-12 [206,210-212]. SSI from barley endosperm shows no affinity for maltotriose or maltotetraose [213]. A recent study in wheat, in which SSI expression was suppressed using RNAi technology, showed increased amounts of very short (DP 6-7) chains, significantly reduced amylose levels, and altered granule morphology, including reductions in the small B-granule population [214]. This study also indicates that the effects of SSI suppression in cereals appear to be more severe than in other plants, such as Arabidopsis. The DP 6-7 chains utilized by SSI may well be the products of SBEII (this enzyme class preferentially produces $\alpha-(1 \rightarrow 6)$-branched chains of DP 6-7; see below), and the 
products of SSI (chains of DP 8-12) are ideal substrates for SSII (in cereal endosperms this isoform is sub-divided into SSIIa, to differentiate it from SSIIb found in photosynthetic tissues). The role of SSIIa in cereal endosperms has largely been elucidated through analysis of mutants. In maize endosperm, SSIIa is the product of the sugary2 gene, which is a mutation resulting in more short chains of DP 6-10, fewer chains of DP 12-30, leading to the general conclusion that SSII is responsible for production of intermediate-length glucan chains [215]. Despite SSII being a minor component of the measurable SS activity in cereal endosperm, the loss of SSIIa leads to major effects on starch structure, including reduced starch content, reduced amylopectin chain-length distribution, altered granule morphology, and reduced crystallinity, and increased amylose content [216,217]. Indeed, various mutations (including single nucleotide polymorphisms) in SSIIa are responsible for altered rice starch quality (cooking quality characteristics reflected in variations in gelatinization temperature (see [218])) and are the basis for the distinction between indica and japonica types [219-224]. Mutations of SSII in dicot storage tissues, such as pea (Pisum sativum L.) and potato (Solanum tuberosum L.), produce similar starch phenotypes as their counterparts in monocots (see [141]), suggesting that functional specificity of some SS isoforms was established prior to the divergence of the monocots and dicots. Both SSI and SSII are also localized within the starch granules [202,221,225], and have been shown to interact with other enzymes of starch biosynthesis, notably the SBEII class in cereal endosperm, as well as SSIII [226-228]. Loss of SSIIa in cereal endosperms, e.g., in wheat, barley, or the sugary2 mutant of maize leads to the loss of other proteins from the starch granule [229-231], and studies by Liu et al. [231] showed that SSIIa was a central component of a protein complex with SSI and SBEIlb, and is involved in mediating the movement of all the components of this protein complex into the starch granule. The SSI/SSIIa/SBEIIb protein complex is probably involved in synthesis of amylopectin clusters (see review of starch structure by Bertoft in this Special Issue).

The function of SSIII in starch biosynthesis appears to extend beyond its catalytic activity, and probably includes the involvement in the regulation of other starch biosynthetic enzymes through protein-interaction and starch-binding domains located at the $\mathrm{N}$-terminus.

SSIII represents a high proportion of measurable SS activity in cereal endosperms such as maize, barley, and rice, and is second only to that of SSI [211,217,232]. Two tissue-specific isoforms of SSIII exist, and are encoded by separate genes, SSIIIa in the endosperm, and SSIIIb in the leaf $[233,234]$. In common with other enzymes of the starch biosynthetic pathway, the catalytic function of SSIII has largely been deduced from mutant studies. Cereals lacking SSIII show a marked reduction in longer, cluster-spanning B-chains (for nomenclature of glucan chains in amylopectin see review by Bertoft in this Special Issue), as well as alterations in the short (A and B) chains, suggesting that the primary role of this enzyme is amylopectin synthesis $[235,236]$. Maize mutants lacking SSIII produce an endosperm with a glassy, dull appearance (and are termed $d u 1$ mutants) [237], a phenotype that is only conspicuous in Waxy (amylose-free) backgrounds [180]. Analysis of amylopectin from du1 maize and rice show altered granule morphology and crystallinity, and a reduction in long glucan chains (DP $\geq 30$ ), suggesting a role for SSIII in their elongation $[197,235,238,239]$. In vitro biochemical studies with partially purified SSIII from maize endosperm support this notion, as the enzyme displays a higher affinity for amylose (longer glucan chains) when compared with amylopectin and glycogen [240]. A proposed function of SSIII, therefore, is in the provision of long glucan chains extending between amylopectin clusters [241]. However, the impact of loss of SSIII appears to be highly variable and dependent upon genetic background, and suggests that SSIII plays other, perhaps regulatory, roles in the synthesis of the starch granule. SSIII appears to play some overlapping role with SSIV in relation to starch granule bio-genesis, since it plays a key role in granule initiation in plants lacking SSIV, and is capable of unprimed glucan formation in the presence of ADP-Glc [242]. Some of the alterations in amylopectin (and granule) structure in cereal endosperms lacking SSIII, e.g., modified short glucan chains and increased amylose content, may be accounted for by the indirect effects of SSIII on other genes of starch synthesis. Studies in various cereals lacking SSIII also report enhanced protein contents and activities of SSI and GBSSI and reduced SBEIIa activity [217,232,235,243-245], leading to the 
suggestion SSIII is a regulator of other genes of starch synthesis. SSIII is the largest of the SS isoforms (for example, rice SSIII is a $230 \mathrm{kDa}$ polypeptide [234]) and possesses a long amino acid extension at the N-terminus, termed the SSIII homology domain (SSIIIHD). The SSIIIHD contains starch-binding domains, two coiled-coil domains and a consensus motif for binding 14-3-3 proteins. The SSIIIHD is involved in protein-protein interactions with other starch biosynthetic enzymes (see below) and glucan binding $[226,227,246,247]$.

SSIV is the most recently discovered form of higher plant SSs [234], and it is phylogenetically related to SSIII [248]. In addition to structural similarities with other SSs (e.g., two ADP-Glc-binding domains etc.), SSIV possesses a unique (SSIV-specific) N-terminus, which includes two coiled-coil domains and a putative 14-3-3 protein binding domain [248]. Two isoforms of SSIV exist in plants, SSIVa and SSIVb, which are differentially expressed in endosperm and leaf tissues, respectively [248]. In vitro studies with SSIV indicate that glucan chain elongation requires the presence of pre-existing glucan, and the enzyme is particularly active with maltotriose [242]. The precise role for SSIV in starch biosynthesis is not clear, since the effects of loss of the enzyme are different in the limited studies and plants, and may be related to whether the tissue is synthesizing transient (leaf) or storage starch (endosperm). Initial studies on SSIV used an ssIV T-DNA insertion mutant of Arabidopsis (which makes transient starch in its leaves) to attempt to elucidate its function. This reverse genetics approach showed that $s s I V$ mutants accumulate a single large starch granule, as opposed to the normal approximately $4-5$ ellipsoid granules per chloroplast, and mutant granules showed alterations in central (hilum) structure $[249,250]$, indicating a role for SSIV in controlling the number of starch granules within a plastid. An ssIII/ssIV double mutant failed to produce starch, indicating a role for both of these SSs in granule initiation in Arabidopsis leaf chloroplasts [242,251]. For a review of starch granule initiation the reader is referred to a review by D'Hulst and Mérida [252]. Recently, a role for plastidial starch phosphorylase (SP, see below) has been proposed for starch granule initiation in chloroplasts, in addition to SSIII and SSIV [253,254]. However, studies with $s s I V$ mutants in the endosperm of japonica rice show very different effects on storage starch synthesis. An ssIV mutant lacking SSIVb showed no noticeable effect on endosperm starch content or structure, although a ssIII/ssIV double mutant, though being able to produce starch, formed single, loose spherical granules, as opposed to compact, compound granules that are characteristic of many members of the Ehrhartoideae (e.g., Oryza and Microlaena (=Ehrharta) species, see Figure 1) [255]. The function of SSIV may require an unusual sub-plastidial environment, as localization studies in Arabidopsis chloroplasts showed SSIV interacts with fibrillins that are hydrophobic proteins localized to plastidial lipid bodies, termed plastoglobules [256]. The interaction was dependent upon the coiled-coil-containing N-terminal domain specific for SSIV [256,257]. The localization of SSIV in lipid/membrane structures may also provide a clue as to its function in storage starch biosynthesis. It was hypothesized by Toyosawa et al. [255] that SSIV may localize to the membrane-like environment of cross walls (septa) dividing compound starch granules in the Ehrhartoideae. The septa of compound granules contain plastid division proteins such as FtsZ, Min, and PDV2 [258], and the loss of SSIV in the rice mutant (above) may disrupt normal compound granule formation, as observed in the ssIV mutant [255]. The small number of studies in a limited set of species means that it is difficult to draw firm conclusions as to the specific role of SSIV in starch biosynthesis, and it may be that its role and influence on granule initiation varies depending on the nature of the starch being produced (transient or storage). Also, other enzymes, e.g., SP have been implicated in granule initiation (see below).

\subsection{Branch Linkage Formation by Starch Branching Enzymes}

The positioning and frequency of branch points in amylopectin are key distinguishing features of higher plants starches, contributing to their water-insoluble properties and varied structural characteristics. SBEs catalyse a non-reversible reaction generating $\alpha-(1 \rightarrow 6)$ branch linkages in $\alpha-(1 \rightarrow 4)$-linked glucans by hydrolytic cleavage of internal $\alpha-(1 \rightarrow 4)$ bonds and transfer of the released reducing ends to C6 hydroxyls to form the branched structure of amylopectin [259]. The action of 
SBE creates a new non-reducing end oligosaccharide chain, which can be elongated by SSs, and this action can also stimulate SS activity $[260,261]$. The actions of different SBE isoforms in conjunction with specific SSs (above) has a profound impact on amylopectin cluster characteristics and granule architecture [262-265], and genetic studies in Arabidopsis have shown that specific SBE isoforms are required to complement the loss of endogenous SBEs in order to form crystalline competent starch [266]. SBEs are related to the $\alpha$-amylase super-family of enzymes [267], and are able to generate $\alpha-(1 \rightarrow 6)$-linkages on both linear and branched glucan substrates via two types of reaction; following cleavage of the $\alpha-(1 \rightarrow 4)$-linkage SBEs can transfer the cleaved glucan to an acceptor chain which is either part of the original glucan chain (termed intra-chain transfer), or part of an adjacent glucan chain (known as inter-chain transfer) [268,269]. All of the branching enzymes are structurally similar and possess a conserved central $(\beta / \alpha)_{8}$-barrel catalytic A-domain, which is flanked by more variable $\mathrm{N}$ - and $\mathrm{C}$-termini [270]. The $\mathrm{N}$-terminus contains a CBM48 $\alpha$-glucan binding domain, whose distance from the catalytic A-domain is important in determining the length (DP) of the chain transferred [271,272], and the C-terminal domains govern substrate preference and chain transfer rate [273]. Based on amino acid sequence relationships, SBEs are split into two classes, termed class I (B family) and class II (A family). A more general, comprehensive review of branching enzymes can be found elsewhere [274].

Grasses and cereals, in common with most other higher plants, possess both class I and class II SBEs. Class I SBEs generally exist as single isoforms and are expressed predominantly (but not exclusively) in the developing endosperm [275]. Phylogenetic analysis indicates SBEI evolved prior to the monocot-dicot divergence (i.e., approximately 200 million years ago [276]), and its retention in higher plants suggests that it is an important component of starch biosynthesis and plant fitness [277]. In cereals, SBEI is expressed later in endosperm development than the SBEII isoforms [273,278-280]. The minimum chain length requirement for branching differs between the SBEI and SBEII classes. Data for maize endosperm show that for SBEI, it is DP 15, and for the SBEII class enzymes, it is DP 12 [281]. In addition, the two SBE classes also differ in their preference for the length of $\alpha$-glucan chain transferred. Maize SBEI shows a preference for transferring relatively longer glucan chains (up to DP 30, with the majority being DP 10-13), and a high affinity for amylose as a substrate [273,281,282]. The SBEII class transfers shorter chains (DP 6-14) and prefers amylopectin as a substrate [283]. Similar distinctions between chain-length transfer and substrate preferences of the two SBE classes has been demonstrated in other cereals $[279,284]$.

Loss of SBEI activity in cereals has minor measurable effects on storage starch synthesis and composition in the endosperm $[275,285,286]$. However, the loss of SBEI in a SBEIlb-deficient background in maize caused increased branching of amylopectin [287], and the researchers postulated that this result was suggestive of a regulatory role for SBEI in influencing the catalytic activity of other SBE isoforms. Indeed, physical interactions between SBEI and SBEIIb have been reported in endosperm amyloplasts from a number of sources [288-291]. SBEI's role in determination of amylopectin structure may be rather more subtle, as suggested by one recent study showing reduced germination efficiency of SBEI-deficient maize kernels [292]. This work suggests that SBEI somehow produces a granule structure that is more accessible to $\alpha$-amylases produced in the aleurone layer for the degradation of starch reserves during germination.

Cereals are characterized by subfunctionalization of the SBEII class into SBEIIa and SBEIIb isoforms, discrete gene products, which each display specific tissue expression patterns [280,293,294]. Analysis of one of the wild grass progenitors of modern wheat, Tausch's goatgrass (Aegilops tauschii Coss., also known as Aegilops squarrosa), and the model grass Brachypodium distachyon, indicates that the subfunctionalization of the class II SBEs also occurs in wild grasses [280,295]. SBEIIb is expressed specifically in the endosperm tissue, whilst SBEIIa appears to be expressed ubiquitously [296]. The SBEIIb isoform appears to have a more narrow range of glucan transfer preference (DP 6-7) than SBEIIa, and this may be related to the differences in the fine structure of starches from different sources depending on the relative proportions of the two SBEII isoforms [284]. The relative proportions of SBEIIa and SBEIIb is a function of the tissue and the species in which they are expressed, 
and examination of the expression patterns of the SBEIIs in three major cereals highlights this point. In developing wheat endosperm, SBEIIb is expressed at much lower levels than the IIa isoform [297,298]. By contrast, in maize endosperm, SBEIIb is the predominant form, being expressed at approximately 50 times the level of the SBEIIa [294], and it is the most abundant protein in the amyloplast stroma [299], whereas in barley, both isoforms are expressed to an equivalent degree in the endosperm [300,301]. Studies with barley at very early stages of endosperm development (0-1 DAP) indicate that SBEIIa is the only detectable SBE isoform, and it has been suggested that SBEs and SP (see later) play a role in granule initiation [302]. SBEII isoforms appear to play a major role in determining amylopectin structure, since the loss of SBEII activity produces clear starch phenotypes. The major SBEII isoform in maize endosperm is SBEIIb, and its loss produces the well-known amylose extender $\left(a e^{-}\right)$mutation, resulting in a $20 \%$ reduction in starch synthesis and severely altered starch granule morphology. In addition, $a e^{-}$starch granules are deeply fissured and irregularly shaped [244,303]. Since SBEIIa is a minor component of SBE activity in the endosperm of maize and rice, its loss has relatively minor affects on endosperm starch [304,305], and it appears to play a more prominent role in transient starch synthesis in the chloroplast [292]. The $a e^{-}$mutation in maize and rice produces a so called 'high-amylose' starch, which is characterized by long internal chain lengths of amylopectin, and less frequently branched outer chains compared with normal starches [306], leading to alterations in granule packing and a less ordered structure than wild-type [307]. High-amylose starches are also called resistant starches, as they are more resistant to $\alpha$-amylase digestion than normal starches. Because of the relative expression of SBEIIa and SBEIIb in wheat endosperm, the production of high-amylose wheat starch involves the suppression of both genes encoding SBEIIa and SBEIIb, resulting in starches containing $>70 \%$ amylose [297]. RNAi suppression of all three SBE isoform activities in barley such that most of the measurable activity is lost, resulting in a severe high amylose starch phenotype [308]. In both wheat and barley, the suppression of SBEII isoforms through TILLING and RNAi technologies has resulted in high amylose endosperm starches [309-311].

SBEs are partitioned between the plastid stroma and the starch granule. A proportion of all SBEs is embedded in the starch granule matrix and form part of the group of proteins known as granule-associated proteins [201,202,312-314]. The precise mechanism that is responsible for granule-association of SBEs and other enzymes, such as isoforms of SS (see above), is not completely understood, and may vary for different enzymes and enzyme complexes. Evidence suggests that some granule-associated proteins become entrapped in the granule through association in heteromeric protein complexes, the formation of which is controlled by protein phosphorylation $[289,315,316]$. All SBE isoforms in cereal endosperms are found in protein complexes in association with other starch biosynthetic enzymes, e.g., SSs, and many of the protein complexes identified contain SBEs (for recent reviews on protein complexes associated with starch biosynthesis see [228,317]. The precise function of the various protein complexes identified in amyloplasts remains unclear. However, the assembly of protein complexes of starch biosynthetic enzymes alters the kinetic characteristics of enzymes, such as the SBEs, e.g., increasing substrate affinity $[231,288,318]$ and the association of SBE and SS isoforms in catalytically functional protein complexes may enable the formation of optimally branched glucan structures that are required for the formation of the semi-crystalline starch granule. Association of SBEs and SSs may also be important in optimising the ratios of these activities, as a number of studies have shown that imbalance in the SS:SBE ratio reduces the crystallinity of the resultant granule $[265,319]$.

\subsection{Debranching Enzymes}

Debranching enzymes (DBEs) hydrolyze $\alpha-(1 \rightarrow 6)$-branch linkages in polyglucans, and in many biological systems this activity is associated with glucan degradation and the release of carbohydrate storage reserves. However, plants and algae have recruited and adapted this class of enzymatic activity for the biosynthesis of starch, such that they are considered as an essential component of the starch biosynthetic machinery. Two groups of DBEs exist in plants; the isoamylase-type (of which, three forms exist in angiosperms; isoamylase-1 (ISA1), isoamylase-2 (ISA2), and isoamylase-3 (ISA3)), and all 
debranch $\alpha-(1 \rightarrow 6)$-linkages in amylopectin, and the pullulanase-type (also known as limit-dextrinase, LDA), which can debranch pullulan (a fungal polymer of malto-triose residues), but whose precise substrate preference in plants is unknown. Like SBEs, DBEs are part of the $\alpha$-amylase "super-family" of enzymes and possess a starch-binding domain, and both groups of DBEs in higher plants share a structurally similar N-terminal domain. In the ISA enzymes the function of the N-terminal domain may be to facilitate interactions between ISA1 and ISA2 (see below) [320]. The main function of both ISA3 and LDA is in the process of starch degradation and turnover [321-324], which is outside the scope of this review, and therefore these enzymes will not be discussed further.

The loss of ISA1 leads to marked phenotypes (termed sugary mutants) in many cereals and their progenitors. sugary mutants lacking ISA1 activity, or the non-catalytic ISA2, show reduced starch content and accumulation of a disordered water-soluble polysaccharide, termed phytoglycogen, which suggests an important role for these isoforms in forming crystalline-competent starch granules [325-330]. Consequently, an attractive model for the role of ISA1 and ISA2 in starch biosynthesis is in so-called pre-amylopectin trimming, whereby ISA isoforms trim/remove inappropriately spaced and positioned $\alpha$ - $(1 \rightarrow 6)$-branch linkages that are formed on the surface of the growing granule [331] by the actions of SSs and SBEs. In this model, trimming of $\alpha-(1 \rightarrow 6)$-branch points on such structures by ISAs allows for glucan chains to assemble into a water insoluble structure via the formation of parallel double helices [332], leading to polysaccharide aggregation [333,334]. In this model, loss of ISA1 or ISA2 creates an abundance of branch points leading to unfavourable conditions for the formation of crystalline lamellae, resulting in the less ordered phytoglycogen. Recent structural studies with ISA1 from the green alga Chlamydomonas reinhardtii indicate that the enzyme has a relatively low affinity towards tightly spaced branches, supporting its proposed role in glucan trimming model [335]. Nevertheless, although ISA mutants accumulate large quantities of phytoglycogen (in maize, this is the basis of some "sweetcorn" varieties), many of these mutants are able to synthesize some starch [320,336], indicating that ISA activity is not a mandatory requirement for crystalline-competent amylopectin formation. Other studies suggest that glucan chain composition is important in the process of granule formation, for example, some japonica rice lines (with reduced SSIIa, see above) with isa1 mutation completely lack starch [337]. However, studies in the model plant Arabidopsis show that leaf starch synthesis is completely lost, and is replaced by phytoglycogen in a isa1/isa2/isa3/lda mutant lacking all DBEs [338]. In addition, the study by Streb et al. [338] also re-enforces the conclusions drawn from previous studies in maize and rice that all of the DBEs show some degree of overlap in their activities with regard to amylopectin biosynthesis $[321,339,340]$. Interestingly, loss of $\alpha$-amylase3 (AMY3) in the isa1/isa2/isa3/lda mutant background partially restored starch synthesis [338]. This important finding supports earlier findings that are mentioned above, that ISA1 and ISA2 are non-essential for amylopectin synthesis, but rather, their role is in assistance and promotion of the formation of water-insoluble glucan structures. In addition, the study by Streb is in agreement with previous studies in Arabidopsis suggesting that phytoglycogen is prone to degradation by amylolytic enzymes [341], and formation of semi-crystalline amylopectin at the surface of the nascent granule protects the structure from degradative enzymes during starch synthesis. The degradative role of DBEs may also serve another function, breaking down branched glucans, which could act as initiation/nucleation sites for new starch granules. Evidence in support of this "clearing" role comes from studies in barley and rice, whereby the loss of ISA activity leads to an increase in starch granule initiation [327,342], which is consistent with the idea that ISAs suppress the sites of new granule initiation, yet are probably not directly involved in initiating granule synthesis.

ISA1 is catalytically active, whereas ISA2 lacks amino acid residues that are essential for catalytic activity, rendering it likely non-catalytic. In some species, ISA1 and ISA2 operate exclusively as a heteromeric complex, with both of the isoforms being required for catalytic activity [322,341,343,344]. ISA2 appears to act in a regulatory role, modifying catalytic properties of ISA1 and stabilizing the heteromeric complex $[343,345]$. However, in cereal endosperms such as maize and rice, homomeric complexes of ISA1 are found together with the heteromeric ISA1/ISA2 complex [346,347]. It appears 
that in cereal endosperm, the ISA1 homomer is sufficient for normal starch synthesis, as isa2 mutants in rice and maize show no significant alterations to storage starch synthesis [346,347]. Despite the operation of the ISA1 homomer in cereal endosperm, studies with the rice endosperm ISA1/ISA2 heteromer indicate increased thermostability and affinity for phytoglycogen compared with the ISA1 homomer [348]. The presence of the ISA1/ISA2 heteromer in addition to the ISA1 homomer may impart flexibility in relation to environmental challenges.

\subsection{Starch Phosphorylase}

Starch phosphorylase (SP) catalyses a reversible (equilibrium) reaction in either a biosynthetic direction, transferring glucosyl units from Glc1P to the non-reducing end of $\alpha-1,4$-linked glucan chains producing $\mathrm{Pi}$, or a degradative (phosphorolysis) reaction, whereby $\mathrm{Pi}$ is utilized to produce Glc1P from the removal of Glc from an $\alpha-1,4$-linked glucan chain. SP was initially thought to be the major activity that is responsible for $\alpha$-glucan elongation during starch synthesis [349]. Plants possess both a plastidial form (referred to as Pho1 or L-form) that is characterized by high affinity for MOS and amylopectin, and inhibited by ADP-Glc [350,351], and a cytosolic (Pho2 or PhoH) form of SP, which in vitro, has a high affinity for glycogen and high molecular weight heteroglycan [299,352]. The cytosolic SP is probably involved in metabolism of $\alpha$-glucans that are resulting from starch degradation and are therefore not directly involved in starch biosynthesis. The precise role for SP in starch biosynthesis is not at all clear. SP is present in all tissues synthesizing starch, and its expression in developing endosperm tissue of a number of cereals is closely correlated with periods of active starch accumulation $[299,353,354]$. Genetic studies in rice indicate a role for SP in starch accumulation. Rice mutants lacking Pho1 show shrunken endosperm and altered starch granule characteristics when plants were grown at low temperature, possibly indicating a role for SP in starch accumulation under different environmental conditions [355], although a down-regulation of Pho1 expression in barley had no major effects on starch biosynthesis [354]. In addition, studies of SP from other plant tissues show no compelling evidence for a role in transitory starch turnover [356,357]. SP might be expected to be driven in either a synthetic or a degradative direction by the relative concentrations of its soluble substrates. Metabolite analysis of barley and wheat endosperm tissues indicate high Pi:Glc1P ratios during starch synthesis [159,358], which would suggest that, under these circumstances, the SP reaction favours phosphorolysis ( $\alpha$-glucan degradation). Further support for the notion of SP acting in a phosphorolytic role comes from studies with maize endosperm amyloplast Pho1, which showed increased phosphorolysis in the presence of MOS [299]. However, studies with rice endosperm Pho1 have shown that the SP reaction, in fact, favours $\alpha$-glucan synthesis, even in the presence of a high Pi:Glc1P ratio ([359] Hwang 2010). Studies with barley and rice Pho1 indicate that the protein is expressed at very early stages of endosperm development (0-3 DAP) [302,360], leading to the suggestion that SP plays a role in granule initiation. Early stages of endosperm development are characterized by relatively low ADP-Glc levels, in part as a result of an active ADP-Glc pyrophosphatase [361], and allowing for SP to elongate short MOS (DP 4-19). Moreover, recent studies with the rice and barley Pho1 indicate that the enzyme is capable of producing and extending MOS solely from Glc1P (i.e., in the absence of $\alpha$-glucan primer [302]. If SP plays a role in granule initiation, as indicated by these studies (and those of Malinova et al. [254] in the above Section 5.2.2), it is not yet clear whether this is in concert with the SSIII/SSIV-mediated pathway or if the two pathways operate separately under different circumstances. It has been argued that SP and SBE activities acting in concert produce branched glucans resistant to phosphorolysis in the early stages of endosperm development and potential initiation points for granule synthesis to continue [302,362]. Interestingly, Pho1 from a number of cereal endosperms has been shown to form protein complexes with SBE isoforms $[288,291,363]$ which supports a role for SP in starch biosynthesis. Unlike many of the SSs and SBEs, SP is not normally found to be associated with the starch granule. However, SP is found associated with starch granules in the amylose extender $\left(a e^{-}\right)$mutant of maize, which lacks 
SBEIIb. In $a e^{-}$maize, SBEI and SP associate with SS isoforms in place of SBEIIb and become entrapped in the starch granule $[208,310]$.

Phosphorylases from a number of plant tissues occur as homotetrameric or homodimeric assemblies [302,364-366]. Elution profiles of maize Pho1 from gel permeation chromatography is consistent with a homotetrameric form of SP, although evidence suggests SP may exist as monomers or lower complexity multimers when associating with other enzymes of starch synthesis $[315,363]$.

Another role for Pho1 could be in controlling MOS availability, which is required for amylose synthesis (see above), and acting in a "clearing" role similar and complementary to that proposed for the DBEs by Zeeman. One proposal is that D-enzymes (see below) work in conjunction with SP, contributing to starch synthesis via phosphorolysis [367]. According to this model, short chain MOS liberated by DBEs during starch synthesis (see above) are converted to longer-chain glucans by D-enzyme (see below), which in turn are available for phosphorolysis by SP, liberating Glc1P for ADP-Glc synthesis by plastidial AGPase. In fact, the phosphorolytic reaction of SP is stimulated by the presence of D-enzyme $[368,369]$, and recent biochemical experiments in rice endosperm have demonstrated rice Pho1 and D-enzyme form a protein complex, which alter the substrate affinities for each component of the complex (see section below) [370]. A role for SP in controlling MOS availability is not mutually exclusive with the proposed role of SP in granule initiation.

\subsection{Disproportionating Enzyme}

As discussed above, MOS generated through the actions of DBEs or SP can be further utilized by plastidial 1,4- $\alpha$-D-glucan:1,4- $\alpha$-D-glucan, 4- $\alpha$-D-glucanotransferase (disproportionating enzyme, D-enzyme). D-enzyme is found in all starch-containing organs of plants [371], but as with SP, its role is not completely clear, and may well be multifarious. Like SP, D-enzyme is found in both the cytosol and the plastid, making the latter isoform relevant in starch synthesis and turnover in the plastid. D-enzyme transfers two glucosyl units from malto-triose onto a longer $\alpha$-glucan chain, resulting in a glucosyl monomer, which may become available for export from the plastid via the Glc transporter in the inner envelope membrane [372,373]. Knock-out mutants of D-enzyme in chloroplasts show reduced rates of nocturnal starch degradation [374], indicating that this enzyme plays a part in starch turnover. However, the actions of the enzyme also indicate that it may play a role in starch synthesis via the modification of MOS as generated by DBEs and or SP (see Figure 3). Analysis of D-enzyme levels in the developing endosperm of wheat is consistent with a role in starch biosynthesis [375]. In vitro both the wheat and rice endosperm D-enzyme was able to use maltoheptaose as a donor for the addition of glucans to amylopectin or glycogen $[375,376]$. Recent studies with the rice endosperm D-enzyme, which is able to form a protein complex with SP, shows that SP is able to utilize the products of transglycosylation (Glc and maltotriose), substrates that it would otherwise be incapable of utilizing on its own [370]. The precise role of D-enzyme in developing endosperm tissues remains unclear.

\subsection{Reversible Phosphorylation of $\alpha$-Linked Glucans}

All of the plant starches contain differing amounts of covalently-linked phosphate, the only known in vivo modification of starch. Starch phosphorylation is mediated by two plastidial dikinases, glucan water-dikinase (GWD) and phospho-glucan water-dikinase (PWD), which transfer the $\beta$-phosphate from ATP onto a glucosyl residue of an $\alpha$-glucan. The majority of phosphate residues on starch are in the C6 position [377], catalyzed by GWD, and a minor proportion (20-30\% of total) of glucosyl residues are phosphorylated in the $\mathrm{C} 3$ position by $\mathrm{PWD}$, which acts on the pre-phosphorylated $\alpha$-glucan that is produced by GWD [378-380]. A very minor proportion of glucosyl residues are phosphorylated in the $\mathrm{C} 2$ position by an unknown mechanism. The proportion of phosphate on starch is generally low $(0.1-0.4 \%)$, and storage starches of cereal endosperms have the lowest levels of phosphorylation (generally less than $0.01 \%$ ), with transient leaf starches showing higher degrees of glucan phosphorylation, and the highest levels of starch phosphorylation being observed in potato (Solanum tuberosum L.) tuber (approximately 0.5\%) [377,381]. The introduction of phosphate groups 
into $\alpha$-glucan chains causes structural alterations, probably via electrostatic interactions between neighbouring phosphate residues, leading to local hydration and solubilization of crystalline structures. Such activity allows for hydrolytic enzymes to act, and it is thought that this modification helps control starch turnover [380], since plants that are lacking GWD activity show an excess of leaf starch at the end of the night [382]. However, phosphate deposition on glucans also occurs during grain development and storage starch biosynthesis in cereals such as wheat and barley [360,383], possibly allowing accessibility for both hydrolytic and biosynthetic activities, making the role of GWD and PWD in starch metabolism more complex. Manipulation of $\alpha$-glucan phosphorylation of cereal starch has resulted in unexpected results. For example, the down regulation of GWD in wheat endosperm resulted in a remarkable increase in plant biomass and a $29 \%$ increase in grain yield [383]. Over-expression of potato GWD in rice endosperm resulted in alterations in starch granule morphology and physicochemical characteristics [384].

\section{Starch Granule Growth, Size and Morphology}

Some of the enzymes that are involved in the pathway of starch biosynthesis may well be involved in granule initiation as discussed, although a complete picture of the factors that are controlling granule initiation and granule size remain unclear. Granule formation emanates from a central location, termed the hilum, and is thought to be essential for granule initiation/priming [385]. The structure of the hilum is not known, but it appears to be made up of less organised polyglucan, as glycogen-like structures are associated with the priming of insoluble starch-like polyglucans [386]. To date, there is no evidence for auto-glucosylation activity by SSIII or SSIV acting in a priming role analogous to glycogenin or prokaryotic glycogen synthase. Radially-oriented microtubules appear to grow out of the hilum, and these become the channels that terminate as openings (pores) on the granule surface of many cereal starch granules [387-389], including both A- and B-type granules of the Festucoid grasses [390]. Analysis of these channels in the endosperm of maize shows that there are actin-like and tubulin-like (FtsZ) proteins present, along with proteins that are involved in starch biosynthesis, such as AGPase and SS [391]. The presence of FtsZ in these channels is interesting, given its involvement in plastid division and the determination of granule morphology (see Section 5.2.2 above on SSIV, and this section below), and it also implies physical connections between the cytosol, plastid stroma, and starch granule. Analysis of developing endosperm cells of wheat suggests that at initial stages of granule deposition, the enzymes of starch biosynthesis associate with plastid tubuli. In addition, there appears to be a direct relationship between starch granule volume and amyloplast tubule volume [58].

There is huge variation in the sizes of starch granules from different plant species [392,393], and granule size is an important factor for many food and industrial applications [394,395]. Three major starch granule morphologies exist within the Poaceae: (1) compound granules, which are made up of tightly packed polygonal granules arranged in spherical-like structures with membranous cross walls termed septa, and are typically found in rice and other members of the Ehrhartoideae [258] and Bambusoideae [396]; (2) simple granules, discrete granules of varying size (2-30 $\mu \mathrm{m})$ and shape, e.g., polyhedral, lenticelullar, or spherical, and found in maize and sorghum [392,397]; and, (3) granules with a bimodal size distribution, typically a mix of small spherical (B-type) and large lenticellular (A-type) granules, and are generally found in the Festucoid family of temperate grasses, such as goatgrass (Aegilops peregrina Hack.), and cereals such as wheat, barley, and rye [398-401]. Evidence suggests that compound starch granules represent the ancestral state in the Poaceae, e.g., Sorghum italica is the earliest diverging lineage within the PACMAD clade, and is the only member of this group with compound granules in the endosperm ([1,402-404] (see Figure 1) and simple or bimodal granules occur in only more recently diverged lineages. Brachypodium is phylogenetically closer to wheat (bimodal starch granules) than maize (simple starch granules) [405], yet shows only small B-type (and C-type) granules in the endosperm $[398,406]$. In the grasses and cereals of the Festucoid family, large lenticular-shaped A-type granules (10-35 $\mu \mathrm{m}$ diameter) are formed early in endosperm development, whilst the smaller, near-spherical B-type granules (averaging 5-9 $\mu \mathrm{m}$ in diameter) are 
formed later [407-409]. A third, smaller, class of starch granules $(<5 \mu \mathrm{m}$, termed C-type granules) in cereals such as wheat has been suggested [410]. Isolating and quantifying C-type granules is technically difficult, and has therefore led to their inclusion as B-type granules in many studies. Studies with ancestral grass species indicates variations in starch granule size characteristics, for example, analysis of endosperm starch from a range of Aegilops species revealed marked differences in starch characteristics when compared with related cultivated species, such as wheat. Aegilops starches showed lower proportions of small B-granules in the endosperm [411]. Analysis of A- and B-type starch granules from developing wheat endosperm indicates that they have distinct physicochemical properties [408,409,412-414] and their biosynthesis may involve different groups of enzymes and protein complexes [290]. In wheat endosperm, it has been proposed that the various classes of starch granules (the large A-type, and smaller B- and C-type granules) are produced in different cell types during different stages of endosperm development $[58,400,408]$. Other studies have shown that the smaller B-type granules that are present in wheat and barley form inside protrusions from the amyloplast, termed stromules $[415,416]$. The selective advantage that is conferred upon temperate grasses in producing a bi/trimodal distribution of starch granules in the endosperm is unclear. However, there may be a selective advantage in forming smaller-sized granules, e.g., it may offer a more efficient means of packing more stored carbohydrate in cells, or allow for more efficient germination under specific environmental conditions. Different size classes of starch granule in the same plant, such as in the Festucoid grasses, is unwanted for some applications, e.g., fermentation where uniformed size is preferred, or other applications involving sedimentation where small B-type granules are lost as industrial waste [143]. The mechanisms underlying starch granule size and morphology are not clearly understood, as evidenced by the wide range of perturbations leading to altered granule size and morphology. In cereals, granule number and morphology is affected by isoamylase-type DBEs, as mutations in ISA in barley endosperm were related to the loss of A- and B-granules and appearance of compound starch granules [321,327]. Down-regulation of a pullulanase-type DBE inhibitor activity in barley causes a reduction in the small (B-type) granules, reduces amylose content, alters amylopectin glucan chain-length distribution, and reduces starch content [417]. QTL mapping studies in the wild wheat Aegilops peregrina identified a gene locus, termed Bgc-1 that is located on the short arm of chromosome 4S, which appears to control the initiation or synthesis of B-granules [418]. Recent deletion studies in bread wheat detected orthologous Bgc-1 regions, which, when deleted, result in the loss of B-granules in the endosperm, but interestingly, no yield penalty [419]. The SS isoforms involved in granule initiation (SSIII and SSIV, see above) clearly play a role in determining granule size and number, but other proteins are likely to be involved. For example, studies on plastid division proteins, such as FtsZ, suggest that the modulation of plastid division through varied FtsZ expression resulted in an altered plastid number and resultant changes in starch granule size and number. Plants with low plastid division had fewer, but larger, starch granules [420]. In rice endosperm, a plastidial CBM48-containing protein (FLO6) interacts with ISA1 and appears to be important in determining granule morphology and amylopectin structure, possibly through guiding ISA1 to the nascent starch granule [421]. Other FLO mutants affecting starch granule morphology include FLO7, which acts at the periphery of the growing rice caryopsis through an unknown mechanism [422]. Other mutants that are linked to altered granule morphology, such as the plastid-localized substandard starch grain4 (SSG4), point to intriguing links between the functioning of basic plastid biological processes and starch formation [423].

\section{Conclusions}

Storage starch biosynthesis in the endosperms of cereals forms the basis of yield in the most important crop plants of the world. This review has outlined the current state of knowledge of this key metabolic pathway in cereals and other members of the grass family, and its relationship to other critical aspects of grass biology, such as endosperm development and carbon supply to the growing grain. Knowledge of the starch metabolic pathway is expanding rapidly, beyond that of the core reactions, 
including newly discovered non-catalytic proteins and regulatory elements. Improved knowledge of the pathway opens up potentially new targets for breeding and plant biotechnology to increase yields and starch quality and functionality. The feasibility of in planta modifications needs to be balanced against the possible use of microbes or chemical methods for starch modification (see [424]). The wild ancestors of the domesticated cereals and forage species offer rich sources of germplasm for crop improvement, either directly, utilizing genes that are associated with starch yield and quality [143], or indirectly, through the improvement in other agronomic traits, such as resistance to biotic and abiotic stresses.

Acknowledgments: Additional support to Michael J. Emes was provided by a sabbatical leave from the University of Guelph. The authors gratefully acknowledge funding from a Natural Sciences and Engineering Research Council of Canada Discovery Grant (435781). The authors thank Zaheer Ahmed for preparation of the image in Figure 2.

Author Contributions: Ian J. Tetlow and Michael J. Emes prepared the manuscript. Both authors read and approved the final manuscript.

Conflicts of Interest: The authors declare no conflict of interest.

\section{References}

1. Paterson, A.H.; Bowers, J.E.; Bruggmann, R.; Dubchak, I.; Grimwood, J.; Gundlach, H.; Haberer, G.; Hellsten, U.; Mitros, T.; Poliakov, A.; et al. The Sorghum bicolor genome and the diversification of grasses. Nature 2009, 457, 551-556. [CrossRef] [PubMed]

2. Comparot-Moss, S.; Denyer, K. The evolution of the starch biosynthetic pathway in cereals and other grasses. J. Exp. Bot. 2009, 60, 2481-2492. [CrossRef] [PubMed]

3. Li, C.; Li, Q.G.; Dunwell, J.M.; Zhang, Y.M. Divergent evolutionary pattern of starch biosynthetic pathway genes in grasses and dicots. Mol. Biol. Evol. 2012, 29, 3227-3236. [CrossRef] [PubMed]

4. Wu, Y.; Zhu, Z.; Ma, L.; Chen, M. The preferential retention of starch synthesis genes reveals the impact of whole-genome duplication on grass evolution. Mol. Biol. Evol. 2008, 25, 1003-1006. [CrossRef] [PubMed]

5. Strömberg, C.A.E. Evolution of Grasses and Grassland Ecosystems. Annu. Rev. Earth Planet. Sci. 2011, 39, 517-544. [CrossRef]

6. Borrill, M. Temperate grasses. In Evolution of Crop Plants; Simmonds, N.W., Ed.; Longman: London, UK, 1976.

7. Piperno, D.R.; Weiss, E.; Holst, I.; Nadel, D. Processing of wild cereal grains in the Upper Palaeolithic revealed by starch grain analysis. Nature 2004, 430, 670-673. [CrossRef] [PubMed]

8. Hardy, K.; Buckley, S.; Collins, M.J.; Estalrrich, A.; Brothwell, D.; Copeland, L.; García-Tabernero, A.; García-Vargas, S.; De La Rasilla, M.; Lalueza-Fox, C.; et al. Neanderthal medics? Evidence for food, cooking, and medicinal plants entrapped in dental calculus. Naturwissenschaften 2012, 99, 617-626. [CrossRef] [PubMed]

9. Prasad, V. Dinosaur Coprolites and the Early Evolution of Grasses and Grazers. Science 2005, 310, 1177-1180. [CrossRef] [PubMed]

10. Mercader, J. Mozambican Grass Seed Consumption during the Middle Stone Age. Science 2009, 326, 1680-1683. [CrossRef] [PubMed]

11. Henry, A.G.; Brooks, A.S.; Piperno, D.R. Microfossils in calculus demonstrate consumption of plants and cooked foods in Neanderthal diets (Shanidar III, Iraq; Spy I and II, Belgium). Proc. Natl. Acad. Sci. USA 2011, 108, 486-491. [CrossRef] [PubMed]

12. Hedden, P. The genes of the Green Revolution. Trends Genet. 2003, 19, 5-9. [CrossRef]

13. Siqueira, G.F.; Pierre, J.S.; El Tahchy, A.; Glassop, D.; Singh, S.; Bonnett, G.D.; Rae, A.L. Sugarcane seed composition and changes during artificial ageing. Crop Pasture Sci. 2015, 66, 1180-1189. [CrossRef]

14. Langer, R.H.M.; Hill, G.D. Agricultural Plants; Cambridge University Press: Cambridge, UK, 1982.

15. Venn, B.J.; Mann, J.I. Cereal grains, legumes and diabetes. Eur. J. Clin. Nutr. 2004, 58, 1443-1461. [CrossRef] [PubMed]

16. Cassidy, A.; Bingham, S.A.; Cummings, J.H. Starch intake and colorectal cancer risk: An international comparison. Br. J. Cancer 1994, 69, 937-942. [CrossRef] [PubMed] 
17. Noakes, M.; Clifton, P.; Nestel, P.; Le Leu, R.; McIntosh, G. Effect of high-amylose starch and oat bran on metabolic variables and bowel function in subjects with hypertriglyceridemia. Am. J. Clin. Nutr. 1996, 64, 944-951. [PubMed]

18. Annison, G.; Topping, D.L. Nutritional Role of Resistant Starch: Chemical Structure vs Physiological Function Primary Structure of Starch Components. Annu. Rev. Nutr. 1994, 14, 297-320. [CrossRef] [PubMed]

19. Godfray, C.; Beddington, J.; Crute, I.; Haddad, L.; Lawrence, D.; Muir, J.F.; Pretty, J.; Robinson, S.; Thomas, S.M.; Toulmin, C. Food Security: The Challenges of Feeding 9 Billion People. Science 2010, 327, 812-818. [CrossRef] [PubMed]

20. Parry, M.A.J.; Hawkesford, M.J. Food security: Increasing yield and improving resource use efficiency. Proc. Nutr. Soc. 2010, 69, 592-600. [CrossRef] [PubMed]

21. Bihmidine, S.; Hunter, C.T.; Johns, C.E.; Koch, K.E.; Braun, D.M. Regulation of assimilate import into sink organs: Update on molecular drivers of sink strength. Front. Plant Sci. 2013, 4, 1-15. [CrossRef] [PubMed]

22. MacNeill, G.J.; Mehrpouyan, S.; Minow, M.A.A.; Patterson, J.A.; Tetlow, I.J.; Emes, M.J. Starch as a source, starch as a sink: The bifunctional role of starch in carbon allocation. J. Exp. Bot. 2017, 1, 1-21. [CrossRef] [PubMed]

23. Setter, T.L.; Parra, R. Relationship of carbohydrate and abscisic acid levels to kernel set in maize under postpollination water deficit. Crop Sci. 2010, 50, 980-988. [CrossRef]

24. Slewinski, T. Non-structural carbohydrate partitioning in grass stems: A target to increase yield stability, stress tolerance, and biofuel production. J. Exp. Bot. 2012, 63, 4647-4670. [CrossRef] [PubMed]

25. Thalmann, M.; Santelia, D. Starch as a determinant of plant fitness under abiotic stress. New Phytol. 2017, 214, 943-951. [CrossRef] [PubMed]

26. Areche, M.; Slafer, G. Grain weight response to increases in number of grains in wheat in a Mediterranean area. Field Crops Res. 2006, 98, 52-59. [CrossRef]

27. Preston, J.C.; Kellogg, E.A. Reconstructing the evolutionary history of paralogous APETALA1/FRUITFULLlike genes in grasses (Poaceae). Genetics 2006, 174, 421-437. [CrossRef] [PubMed]

28. $\mathrm{Xu}$, J.H.; Bennetzen, J.L.; Messing, J. Dynamic gene copy number variation in collinear regions of grass genomes. Mol. Biol. Evol. 2012, 29, 861-871. [CrossRef] [PubMed]

29. Vogel, J.P.; Garvin, D.F.; Mockler, T.C.; Schmutz, J.; Rokhsar, D.; Bevan, M.W.; Barry, K.; Lucas, S.; Harmon-Smith, M.; Lail, K.; et al. Genome sequencing and analysis of the model grass Brachypodium distachyon. Nature 2010, 463, 763-768. [CrossRef] [PubMed]

30. Pollock, C.; Chatterton, N. The Biochemistry of Plants: A Comprehensive Treatise; Preiss, J., Ed.; Academic Press Inc., Ltd.: London, UK, 1988; pp. 109-140.

31. Chatterton, N.J.; Harrison, P.A.; Thornley, W.R.; Draper, E.A. Oligosaccharides in foliage of Agropyron, Bromus, Dactylis, Festuca, Lolium and Phleum. New Phytol. 1990, 114, 167-171. [CrossRef]

32. Schnyder, H. The role of carbohydrate storage and redistribution in the source-sink relations of wheat and barley during grain filling-A review. New Phytol. 1993, 123, 233-245. [CrossRef]

33. Graf, A.; Schlereth, A.; Stitt, M.; Smith, A.M. Circadian control of carbohydrate availability for growth in Arabidopsis plants at night. Proc. Natl. Acad. Sci. USA 2010, 107, 9458-9463. [CrossRef] [PubMed]

34. De Souza, A.; Sandrin, C.Z.; Moraes, M.G.; de Cássia, L. Figueiredo-Ribeiro, R. Diurnal variations of non-structural carbohydrates in vegetative tissues of Melinis minutiflora, Echinolaena inflexa and Lolium multiflorum (Poaceae). Rev. Bras. Bot. 2005, 28, 755-763. [CrossRef]

35. De Figueira, J.A.; Carvalho, P.H.; Sato, H.H. Sugarcane starch: Quantitative determination and characterization. Ciência Tecnol. Aliment. 2011, 31, 806-815. [CrossRef]

36. Gordon, A.J.; Ryle, G.J.A.; Powell, C.E.; Mitchell, D. Export, mobilization, and respiration of assimilates in uniculm barley during light and darkness. J. Exp. Bot. 1980, 31, 461-473. [CrossRef]

37. Gordon, A.J.; Ryle, G.J.A.; Webb, G. The relationship between sucrose and starch during "dark" export from leaves of uniculm barley. J. Exp. Bot. 1980, 31, 845-850. [CrossRef]

38. Nie, G.; Hendrix, D.L.; Webber, A.N.; Kimball, B.A.; Long, S.P. Increased accumulation of carbohydrates and decreased photosynthetic gene transcript levels in wheat grown at an elevated $\mathrm{CO}_{2}$ concentration in the field. Plant Physiol. 1995, 108, 975-983. [CrossRef] [PubMed]

39. Farrar, S.; Farrar, F. Carbon fluxes in leaf blades of barley. New Phytol. 1985, 100, 271-283. [CrossRef]

40. Pollock, C.J. Sucrose accumulation and the initiation of fructan biosynthesis in Lolium temulentum L. New Phytol. 1984, 96, 527-534. [CrossRef] 
41. Cairns, A.J.; Cookson, A.; Thomas, B.J.; Turner, L.B. Starch metabolism in the fructan-grasses: Patterns of starch accumulation in excised leaves of Lolium temulentum L. J. Plant Physiol. 2002, 159, 293-305. [CrossRef]

42. Cairns, A. Starch accumulation in temperate forage grasses. IGER Innov. 2002, 6-9.

43. Francis, S.; Chapman, D.; Doyle, P.; Leury, B.; Egan, A. Non-structural carbohydrate content of a perennial ryegrass cultivar bred for high sugar levels, compared to "normal" perennial ryegrass and white clover. Anim. Prod. Aust. 2002, 24, 73-76.

44. Ciavarella, T.; Simpson, R.; Dove, H.; Leury, B.; Sims, I. Diurnal changes in the concentration of water-soluble carbohydrates in Phalaris aquatica L. pasture in spring, and the effect of short-term shading. Aust. J. Agric. Res. 2000, 51, 749-756. [CrossRef]

45. Cairns, A.J.; Gallagher, J.A. Absence of turnover and futile cycling of sucrose in leaves of Lolium temulentum L.: Implications for metabolic compartmentation. Planta 2004, 219, 836-846. [CrossRef] [PubMed]

46. Lechtenberg, V.; Holt, D.; Youngberg, H. Diurnal variation in nonstructural carbohydrates of Festuca arundinacea (Schreb.) with and without N fertilizer. Agron. J. 1972, 64, 302-305. [CrossRef]

47. Ruckle, M.; Meier, M.; Frey, L.; Eicke, S.; Kölliker, R.; Zeeman, S.; Studer, B. Diurnal Leaf Starch Content: An Orphan Trait in Forage Legumes. Agronomy 2017, 7, 16. [CrossRef]

48. Lunn, J.E.; Hatch, M.D. Primary partitioning and storage of photosynthate in sucrose and starch in leaves of C4 plants. Planta 1995, 197, 385-391. [CrossRef]

49. Sulpice, R.; Pyl, E.-T.; Ishihara, H.; Trenkamp, S.; Steinfath, M.; Witucka-Wall, H.; Gibon, Y.; Usadel, B.; Poree, F.; Piques, M.C.; et al. Starch as a major integrator in the regulation of plant growth. Proc. Natl. Acad. Sci. USA 2009, 106, 10348-10353. [CrossRef] [PubMed]

50. Stitt, M.; Zeeman, S.C. Starch turnover: Pathways, regulation and role in growth. Curr. Opin. Plant Biol. 2012, 15, 282-292. [CrossRef] [PubMed]

51. Zhang, G.; Liu, X.; Quan, Z.; Cheng, S.; Xu, X.; Pan, S.; Xie, M.; Zeng, P.; Yue, Z.; Wang, W.; et al. Genome sequence of foxtail millet (Setaria italica) provides insights into grass evolution and biofuel potential. Nat. Biotechnol. 2012, 30, 549-554. [CrossRef] [PubMed]

52. Austin, R.; Morgan, C.; Ford, M.; Blackwell, R. Contributions to grain yield from pre-anthesis assimilation in tall and dwarf barley phenotypes in two contrasting seasons. Ann. Bot. 1980, 45, 309-319. [CrossRef]

53. Austin, R.; Bingham, J.; Blackwell, R.; Evans, L.; Ford, M.; Morgan, C.; Taylor, M. Genetic improvements in winter wheat yields since 1900 and associated physiological changes. J. Agric. Sci. 1980, 94, 52-59. [CrossRef]

54. Evans, L.T.; Dunstone, R.L. Some physiological aspects of evolution in wheat. Aust. J. Biol. Sci. 1970, 23, 725-741. [CrossRef]

55. Weatherwax, P. The endosperm of Zea and Coix. Am. J. Bot. 1930, 17, 371-380. [CrossRef]

56. Leroux, B.M.; Goodyke, A.J.; Schumacher, K.I.; Abbott, C.P.; Clore, A.M.; Yadegari, R.; Larkins, B.A.; Dannenhoffer, J.M. Maize early endosperm growth and development: From fertilization through cell type. Am. J. Bot. 2014, 101, 1259-1274. [CrossRef] [PubMed]

57. Brown, R.; Lemmon, B.; Olsen, O. Development of the endosperm in rice (Oryza sativa L.): Cellularization. J. Plant Res. 1996, 109, 301-313. [CrossRef]

58. Briarty, L.G.; Hughes, C.E.; Evers, A.D. The Developing Endosperm of Wheat-A Stereological Analysis. Ann. Bot. 1979, 44, 641-658. [CrossRef]

59. Bosnes, M.; Weideman, F.; Olsen, O.-A. Endosperm differentiation in barley wild-type and sex mutants. Plant J. 1992, 2, 661-674. [CrossRef]

60. Shull, J.; Chandrashekar, A.; Kirleis, A.; Ejeta, G. Development of Sorghum (Sorghum bicolor) endosperm in varieties of varying hardness. Food Struct. 1990, 9, 253-267.

61. Sabelli, P.A.; Larkins, B.A. The Development of Endosperm in Grasses. Plant Physiol. 2009, 149, 14-26. [CrossRef] [PubMed]

62. Opanowicz, M.; Hands, P.; Betts, D.; Parker, M.L.; Toole, G.A.; Mills, E.N.C.; Doonan, J.H.; Drea, S. Endosperm development in Brachypodium distachyon. J. Exp. Bot. 2011, 62, 735-748. [CrossRef] [PubMed]

63. Hands, P. Analysis of grain characters in temperate grasses reveals distinctive patterns of endosperm organisation associated with grain shape. J. Exp. Bot. 2012, 63, 6253-6266. [CrossRef] [PubMed]

64. Olsen, O.-A. Nuclear endosperm development in cereals and Arabidopsis thaliana. Plant Cell 2004, 16, S214-S227. [CrossRef] [PubMed]

65. Buttrose, M. Ultrastructure of the developing aleurone cells of wheat grain. Aust. J. Biol. Sci. 1963, 16, 768-774. [CrossRef] 
66. Offler, C.E.; McCurdy, D.W.; Patrick, J.W.; Talbot, M.J. Transfer Cells: Cells Specialized for a Special Purpose. Annu. Rev. Plant Biol. 2003, 54, 431-454. [CrossRef] [PubMed]

67. Ohdan, T.; Francisco, P.B.; Sawada, T.; Hirose, T.; Terao, T.; Satoh, H.; Nakamura, Y. Expression profiling of genes involved in starch synthesis in sink and source organs of rice. J. Exp. Bot. 2005, 56, 3229-3244. [CrossRef] [PubMed]

68. Uhlmann, N.K.; Beckles, D.M. Storage products and transcriptional analysis of the endosperm of cultivated wheat and two wild wheat species. J. Appl. Genet. 2010, 51, 431-447. [CrossRef] [PubMed]

69. Brocklehurst, P.A. Factors controlling grain weight in wheat. Nature 1977, 266, 348-349. [CrossRef]

70. Chojecki, A.; Gale, M.; Bayliss, M.W. The number and sizes of starch granules in the wheat endosperm, and their association with grain weight. Ann. Bot. (Lond.) 1986, 58, 819-831. [CrossRef]

71. Chojecki, A.; Bayliss, M.; Gale, M. Cell production and DNA accumulation in the wheat endosperm, and their association with grain weight. Ann. Bot. (Lond.) 1986, 58, 809-817. [CrossRef]

72. Jones, R.J.; Schreiber, B.M.N.; Roessler, J.A. Kernel sink capacity in maize: Genotypic and maternal regulation. Crop Sci. 1996, 36, 301-306. [CrossRef]

73. Beckles, D.M.; Thitisaksakul, M. How environmental stress affects starch composition and functionality in cereal endosperm. Starch/Staerke 2014, 66, 58-71. [CrossRef]

74. Reddy, V.M.; Daynard, T.B. Endosperm characteristics associated with rate of grain filling and kernel size in corn. Maydica 1983, 28, 339-355.

75. Commuri, P.D.; Jones, R.J. Ultrastructural characterization of maize (Zea mays L.) kernels exposed to high temperature during endosperm cell division. Plant Cell Environ. 1999, 22, 375-385. [CrossRef]

76. Van Dongen, J.T.; Roeb, G.W.; Dautzenberg, M.; Froehlich, A.; Vigeolas, H.; Minchin, P.E.H.; Geigenberger, P.; Van Dongen, J.T.; Roeb, G.W.; Dautzenberg, M.; et al. Phloem Import and Storage Metabolism Are Highly Coordinated by the Low Oxygen Concentrations within Developing Wheat Seeds. Plant Physiol. 2004, 135, 1809-1821. [CrossRef] [PubMed]

77. Rolletschek, H.; Koch, K.; Wobus, U.; Borisjuk, L. Positional cues for the starch/lipid balance in maize kernels and resource partitioning to the embryo. Plant J. 2005, 42, 69-83. [CrossRef] [PubMed]

78. Rolletschek, H.; Weschke, W.; Weber, H.; Wobus, U.; Borisjuk, L. Energy state and its control on seed development: Starch accumulation is associated with high ATP and steep oxygen gradients within barley grains. J. Exp. Bot. 2004, 55, 1351-1359. [CrossRef] [PubMed]

79. Radchuk, V.; Borisjuk, L. Physical, metabolic and developmental functions of the seed coat. Front. Plant Sci. 2014, 5, 1-17. [CrossRef] [PubMed]

80. Rolletschek, H.; Melkus, G.; Grafahrend-Belau, E.; Fuchs, J.; Heinzel, N.; Schreiber, F.; Jakob, P.M.; Borisjuk, L. Combined Noninvasive Imaging and Modeling Approaches Reveal Metabolic Compartmentation in the Barley Endosperm. Plant Cell 2011, 23, 3041-3054. [CrossRef] [PubMed]

81. Smirnoff, N. Tocochromanols: Rancid lipids, seed longevity, and beyond. Proc. Natl. Acad. Sci. USA 2010, 107, 17857-17858. [CrossRef] [PubMed]

82. Bailly, C.; Kranner, I. Analyses of reactive oxygen species and antioxidants in relation to seed longevity and germination. Methods Mol. Biol. 2011, 773, 343-367. [PubMed]

83. Hendry, G. Oxygen, free radical processes and seed longevity. Seed Sci. Res. 1993, 3, 141-153. [CrossRef]

84. Alonso, A.P.; Val, D.L.; Shachar-Hill, Y. Central metabolic fluxes in the endosperm of developing maize seeds and their implications for metabolic engineering. Metab. Eng. 2011, 13, 96-107. [CrossRef] [PubMed]

85. Young, T.E.; Gallie, D.R. Programmed cell death during endosperm development. Plant Mol. Biol. 2000, 44, 283-301. [CrossRef] [PubMed]

86. Zhou, Z.; Wang, L.; Li, J.; Song, X.; Yang, C. Study on programmed cell death and dynamic changes of starch accumulation in pericarp cells of Triticum aestivum L. Protoplasma 2009, 236, 49-58. [CrossRef] [PubMed]

87. Van Bel, A.J.E. Strategies of Phloem Loading. Annu. Rev. Plant Physiol. Plant Mol. Biol. 1993, 44, $253-281$. [CrossRef]

88. Van Bel, A.J.E.; Helariutta, Y.; Thompson, G.A.; Ton, J.; Dinant, S.; Ding, B.; Patrick, J.W. Phloem: The integrative avenue for resource distribution, signaling, and defense. Front. Plant Sci. 2013, 4, 471. [CrossRef] [PubMed]

89. Turgeon, R. The Role of Phloem Loading Reconsidered. Plant Physiol. 2010, 152, 1817-1823. [CrossRef] [PubMed] 
90. De Schepper, V.; De Swaef, T.; Bauweraerts, I.; Steppe, K. Phloem transport: A review of mechanisms and controls. J. Exp. Bot. 2013, 64, 4839-4850. [CrossRef] [PubMed]

91. Jenner, C.F.; Rathjen, A.J. Factors limiting the supply of sucrose to the developing wheat grain. Ann. Bot. 1972, 36, 729-741. [CrossRef]

92. Fisher, D.B.; Gifford, R.M. Accumulation and Conversion of Sugars by Developing Wheat Grains. Plant Physiol. 1987, 84, 341-347. [CrossRef] [PubMed]

93. Shannon, J.; Dougherty, C. Movement of 14C-Labeled assimilates into kernels of Zea mays L. II. Invertase activity of the pedicel and placento-chalazal tissues. Plant Physiol. 1972, 49, 203-206. [CrossRef] [PubMed]

94. Cochrane, M.P. Morphology of the crease region in relation to assimilate uptake and water loss during caryopsis development in barley and wheat. Aust. J. Plant Physiol. 1983, 10, 473-491. [CrossRef]

95. Thorne, J.H. Developing seeds. Annu. Rev. Plant Physiol. 1985, 36, 317-343. [CrossRef]

96. Weschke, W.; Panitz, R.; Sauer, N.; Wang, Q.; Neubohn, B.; Weber, H.; Wobus, U. Sucrose transport into barley seeds: Molecular characterization of two transporters and implications for seed development and starch accumulation. Plant J. 2000, 21, 455-467. [CrossRef] [PubMed]

97. Krishnan, S.; Dayanandan, P. Structural and histochemical studies on grain-filling in the caryopsis of rice (Oryza sativa L.). J. Biosci. 2003, 28, 455-469. [CrossRef] [PubMed]

98. Felker, F.C.; Shannon, J.C. Movement of 14C-labeled Assimilates into Kernels of Zea mays L: III. An anatomical examination and microautoradiographic study of assimilate transfer. Plant Physiol. 1980, 65, 864-870. [CrossRef] [PubMed]

99. Sosso, D.; Luo, D.; Li, Q.-B.; Sasse, J.; Yang, J.; Gendrot, G.; Suzuki, M.; Koch, K.E.; McCarty, D.R.; Chourey, P.S.; et al. Seed filling in domesticated maize and rice depends on SWEET-mediated hexose transport. Nat. Genet. 2015, 47, 1489-1493. [CrossRef] [PubMed]

100. Vilhar, B.; Kladnik, A.; Blejec, A.; Chourey, P.S.; Dermastia, M. Cytometrical evidence that the loss of seed weight in the miniature1 seed mutant of maize is associated with reduced mitotic activity in the developing endosperm. Plant Physiol. 2002, 129, 23-30. [CrossRef] [PubMed]

101. Jain, M.; Chourey, P.S.; Li, Q.B.; Pring, D.R. Expression of cell wall invertase and several other genes of sugar metabolism in relation to seed development in sorghum (Sorghum bicolor). J. Plant Physiol. 2008, 165, 331-344. [CrossRef] [PubMed]

102. Ou-Lee, T.M.; Setter, T.L. Enzyme activities of starch and sucrose pathways and growth of apical and basal maize kernels. Plant Physiol. 1985, 79, 848-851. [CrossRef] [PubMed]

103. Koch, K.E. Carbohydrate-Modulated Gene Expression in Plants. Annu. Rev. Plant Physiol. Plant Mol. Biol. 1996, 47, 509-540. [CrossRef] [PubMed]

104. Koch, K. Sucrose metabolism: Regulatory mechanisms and pivotal roles in sugar sensing and plant development. Curr. Opin. Plant Biol. 2004, 7, 235-246. [CrossRef] [PubMed]

105. Ruan, Y.L.; Jin, Y.; Yang, Y.J.; Li, G.J.; Boyer, J.S. Sugar input, metabolism, and signaling mediated by invertase: Roles in development, yield potential, and response to drought and heat. Mol. Plant 2010, 3, 942-955. [CrossRef] [PubMed]

106. Barratt, D.H.P.; Derbyshire, P.; Findlay, K.; Pike, M.; Wellner, N.; Lunn, J.; Feil, R.; Simpson, C.; Maule, A.J.; Smith, A.M. Normal growth of Arabidopsis requires cytosolic invertase but not sucrose synthase. Proc. Natl. Acad. Sci. USA 2009, 106, 13124-13129. [CrossRef] [PubMed]

107. Kato, T. Change of Sucrose Synthase Activity in Developing Endosperm of Rice Cultivars. Crop Sci. 1995, 35, 827-831. [CrossRef]

108. Thévenot, C.; Simond-Côte, E.; Reyss, A.; Manicacci, D.; Trouverie, J.; Le Guilloux, M.; Ginhoux, V.; Sidicina, F.; Prioul, J.L. QTLs for enzyme activities and soluble carbohydrates involved in starch accumulation during grain filling in maize. J. Exp. Bot. 2005, 56, 945-958. [CrossRef] [PubMed]

109. Chourey, P.S.; Taliercio, E.W.; Carlson, S.J.; Ruan, Y.L. Genetic evidence that the two isozymes of sucrose synthase present in developing maize endosperm are critical, one for cell wall integrity and the other for starch biosynthesis. Mol. Gen. Genet. 1998, 259, 88-96. [CrossRef] [PubMed]

110. Farré, E.M.; Geigenberger, P.; Willmitzer, L.; Trethewey, R.N. A possible role for pyrophosphate in the coordination of cytosolic and plastidial carbon metabolism within the potato tuber. Plant Physiol. 2000, 123, 681-688. [CrossRef] [PubMed]

111. Appeldoorn, N.J.G.; De Bruijn, S.M.; Koot-Gronsveld, E.A.M.; Visser, R.G.F.; Vreugdenhil, D.; Van Der Plas, L.H.W. Developmental changes in enzymes involved in the conversion of hexose phosphate 
and its subsequent metabolites during early tuberization of potato. Plant Cell Environ. 1999, 22, 1085-1096. [CrossRef]

112. Zeng, Y.; Wu, Y.; Avigne, W.T.; Koch, K.E. Rapid repression of maize invertases by low oxygen. Invertase/sucrose synthase balance, sugar signaling potential, and seedling survival. Plant Physiol. 1999, 121, 599-608. [CrossRef] [PubMed]

113. Richard, B.; Rivoal, J.; Spiteri, A.; Pradet, A. Anaerobic Stress Induces the Transcription and Tranlslation of Sucrose Synthase in Rice. Plant Physiol. 1991, 95, 669-674. [CrossRef]

114. Huber, S.C.; Akazawa, T. A novel sucrose synthase pathway for sucrose degradation in cultured sycamore cells. Plant Physiol. 1986, 81, 1008-1013. [CrossRef] [PubMed]

115. Xu, D.P.; Sung, S.J.; Loboda, T.; Kormanik, P.P.; Black, C.C. Characterization of Sucrolysis via the Uridine Diphosphate and Pyrophosphate-Dependent Sucrose Synthase Pathway. Plant Physiol. 1989, 90, 635-642. [CrossRef] [PubMed]

116. Guglielminetti, L.; Perata, P.; Alpi, A. Effect of Anoxia on Carbohydrate Metabolism in Rice Seedlings. Plant Physiol. 1995, 108, 735-741. [CrossRef] [PubMed]

117. Perata, P.; Pozueta-Romero, J.; Akazawa, T.; Yamaguchi, J. Effect of anoxia on starch breakdown in rice and wheat seeds. Planta 1992, 188, 611-618. [CrossRef] [PubMed]

118. Cheng, W.; Taliercio, E.; Chourey, P. The Miniature1 Seed Locus of Maize Encodes a Cell Wall Invertase Required for Normal Development of Endosperm and Maternal Cells in the Pedicel. Plant Cell 1996, 8, 971-983. [CrossRef] [PubMed]

119. Kleczkowski, L.A. Back to the drawing board: redefining starch synthesis in cereals. Trends Plant Sci. 1996, 1, 363-364. [CrossRef]

120. Kleczkowski, L.A. Glucose activation and metabolism through UDP-glucose pyrophosphorylase in plants. Phytochemistry 1994, 37, 1507-1515. [CrossRef]

121. Sung, S.J.S.; Xu, D.P.; Galloway, C.M.; Black, C.C. A reassessment of glycolysis and gluconeogenesis in higher plants. Physiol. Plant. 1988, 72, 650-654. [CrossRef]

122. Ap Rees, T.; Morrell, S. Carbohydrate metabolism in developing potatoes. Am. Potato J. 1990, 67, 835-847. [CrossRef]

123. Stitt, M. Pyrophosphate as an energy donor in the cytosol of plant cells: An enigmatic alternative to ATP. Bot. Acta 1998, 111, 167-175. [CrossRef]

124. Zeng, Y.; Wu, Y.; Avigne, W.T.; Koch, K.E. Differential Regulation of Sugar-Sensitive Sucrose Synthases by Hypoxia and Anoxia Indicate Complementary Transcriptional and Posttranscriptional Responses1. Plant Physiol. 1998, 116, 1573-1583. [CrossRef] [PubMed]

125. Tomlinson, D.J.; Turner, J.F. Pyruvate kinase of higher plants. Biochim. Biophys. Acta 1973, 329, $128-139$. [CrossRef]

126. Plaxton, W.C. The Organization and Regulation of Plant Glycolysis. Annu. Rev. Plant Physiol. Plant Mol. Biol. 1996, 47, 185-214. [CrossRef] [PubMed]

127. Kurzawska, A.; Gõrecka, D.; Błaszczak, W.; Szwengiel, A.; Paukszta, D.; Lewandowicz, G. The molecular and supermolecular structure of common cattail (Typha latifolia) starch. Starch/Staerke 2014, 66, 849-856. [CrossRef]

128. Wersal, R.M.; Madsen, J.D.; Cheshier, J.C. Seasonal Biomass and Starch Allocation of Common Reed (Phragmites australis) (Haplotype I) in Southern Alabama, USA. Invasive Plant Sci. Manag. 2013, 6, 140-146. [CrossRef]

129. Chourey, P.S.; Nelson, O.E. The enzymatic deficiency conditioned by the shrunken-1 mutations in maize. Biochem. Genet. 1976, 14, 1041-1055. [CrossRef] [PubMed]

130. Miller, M.; Chourey, P. The Maize Invertase-Deficient miniature-1 Seed Mutation Is Associated with Aberrant Pedicel and Endosperm Development. Plant Cell 1992, 4, 297-305. [CrossRef] [PubMed]

131. Fincher, G.B.; Stone, B.A. Cell walls and their components in cereal grain technology. In Advances in Cereal Science and Technology; Pomeranz, Y., Ed.; American Association of Cereal Chemists Inc.: St. Paul, MN, USA, 1986.

132. Yu, X.; Li, B.; Wang, L.; Chen, X.; Wang, W.; Wang, Z.; Xiong, F. Systematic analysis of pericarp starch accumulation and degradation during wheat caryopsis development. PLoS ONE 2015, 10, e0138228. [CrossRef] [PubMed] 
133. Earp, C.F.; McDonough, C.M.; Rooney, L.W. Microscopy of pericarp development in the caryopsis of Sorghum bicolor (L.) Moench. J. Cereal Sci. 2004, 39, 21-27. [CrossRef]

134. Gu, Y.; Wang, Z.; Chen, J.; Zhao, G. The structure and function of pericarp in rice. Acta Agron. Sin. 2002, 28, 439-444.

135. She, K.-C.; Kusano, H.; Koizumi, K.; Yamakawa, H.; Hakata, M.; Imamura, T.; Fukuda, M.; Naito, N.; Tsurumaki, Y.; Yaeshima, M.; et al. A Novel Factor FLOURY ENDOSPERM2 Is Involved in Regulation of Rice Grain Size and Starch Quality. Plant Cell 2010, 22, 3280-3294. [CrossRef] [PubMed]

136. Kang, H.G.; Park, S.; Matsuoka, M.; An, G. White-core endosperm floury endosperm-4 in rice is generated by knockout mutations in the C4-type pyruvate orthophosphate dikinase gene (OsPPDKB). Plant J. 2005, 42, 901-911. [CrossRef] [PubMed]

137. Zhang, Z.; Zheng, X.; Yang, J.; Messing, J.; Wu, Y. Maize endosperm-specific transcription factors $\mathrm{O}_{2}$ and $\mathrm{PBF}$ network the regulation of protein and starch synthesis. Proc. Natl. Acad. Sci. USA 2016, 113, 10842-10847. [CrossRef] [PubMed]

138. Wang, J.C.; Xu, H.; Zhu, Y.; Liu, Q.Q.; Cai, X.L. OsbZIP58, a basic leucine zipper transcription factor, regulates starch biosynthesis in rice endosperm. J. Exp. Bot. 2013, 64, 3453-3466. [CrossRef] [PubMed]

139. Pérez, S.; Bertoft, E. The molecular structures of starch components and their contribution to the architecture of starch granules: A comprehensive review. Starch/Staerke 2010, 62, 389-420. [CrossRef]

140. Tetlow, I.J. Starch biosynthesis in developing seeds. Seed Sci. Res. 2011, 21, 5-32. [CrossRef]

141. Pfister, B.; Zeeman, S.C. Formation of starch in plant cells. Cell. Mol. Life Sci. 2016, 73, 2781-2807. [CrossRef] [PubMed]

142. Lloyd, J.R.; Kossmann, J. Transitory and storage starch metabolism: Two sides of the same coin? Curr. Opin. Biotechnol. 2015, 32, 143-148. [CrossRef] [PubMed]

143. Blennow, A.; Jensen, S.L.; Shaik, S.S.; Skryhan, K.; Carciofi, M.; Holm, P.B.; Hebelstrup, K.H.; Tanackovic, V. Future cereal starch bioengineering: Cereal ancestors encounter gene technology and designer enzymes. Cereal Chem. 2013, 90, 274-287. [CrossRef]

144. Brozynska, M.; Furtado, A.; Henry, R.J. Genomics of crop wild relatives: Expanding the gene pool for crop improvement. Plant Biotechnol. J. 2016, 14, 1070-1085. [CrossRef] [PubMed]

145. Hajjar, R.; Hodgkin, T. The use of wild relatives in crop improvement: A survey of developments over the last 20 years. Euphytica 2007, 156, 1-13. [CrossRef]

146. Ghosh, H.; Preiss, J. Adenosine diphosphate glucose pyrophosphorylase: A regulatory enzyme in the biosynthesis of starch in spinach leaf chloroplasts. J. Biol. Chem. 1966, 241, 4491-4504. [PubMed]

147. Thorbjørnsen, T.; Villand, P.; Denyer, K.; Olsen, O.A.; Smith, A.M. Distinct isoforms of ADPglucose pyrophosphorylase occur inside and outside the amyloplasts in barley endosperm. Plant J. 1996, 10, $243-250$. [CrossRef]

148. Tetlow, I.J.; Davies, E.J.; Vardy, K.A.; Bowsher, C.G.; Burrell, M.M.; Emes, M.J. Subcellular localization of ADPglucose pyrophosphorylase in developing wheat endosperm and analysis of the properties of a plastidial isoform. J. Exp. Bot. 2003, 54, 715-725. [CrossRef] [PubMed]

149. Sikka, V.; Choi, B.; Kavakli, I.; Sakulsingharoj, C.; Gupta, S.; Ito, H.; Okita, T. Subcellular compartmentation and allosteric regulation of the rice endosperm ADPglucose pyrophosphorylase. Plant Sci. 2001, 161, 461-468. [CrossRef]

150. Denyer, K.; Dunlap, F.; Thorbjørnsen, T.; Keeling, P.; Smith, A.M. The Major Form of ADP-Glucose Pyrophosphorylase in Maize Endosperm is Extra-Plastidial. Plant Physiol. 1996, 112, 779-785. [CrossRef] [PubMed]

151. Tsai, C.-Y.; Nelson, O. Starch-deficient maize mutant lacking adenosine diphosphate glucose pyrophosphorylase activity. Science 1966, 151, 341-343. [CrossRef] [PubMed]

152. Lee, S.K.; Hwang, S.K.; Han, M.; Eom, J.S.; Kang, H.G.; Han, Y.; Choi, S.B.; Cho, M.H.; Bhoo, S.H.; An, G.; et al. Identification of the ADP-glucose pyrophosphorylase isoforms essential for starch synthesis in the leaf and seed endosperm of rice (Oryza sativa L.). Plant Mol. Biol. 2007, 65, 531-546. [CrossRef] [PubMed]

153. Johnson, P.E.; Patron, N.J.; Bottrill, A.R.; Dinges, J.R.; Fahy, B.F.; Parker, M.L.; Waite, D.N.; Denyer, K.A. Low-starch barley mutant, Risø 16, lacking the cytosolic small subunit of ADP-glucose pyrophosphorylase, reveals the importance of the cytosolic isoform and the identity of the plastidial small subunit. Plant Physiol. 2003, 131, 684-696. [CrossRef] [PubMed] 
154. Kirchberger, S.; Tjaden, J.; Ekkehard Neuhaus, H. Characterization of the Arabidopsis Brittle1 transport protein and impact of reduced activity on plant metabolism. Plant J. 2008, 56, 51-63. [CrossRef] [PubMed]

155. Bowsher, C.G.; Scrase-Field, E.F.A.L.; Esposito, S.; Emes, M.J.; Tetlow, I.J. Characterization of ADP-glucose transport across the cereal endosperm amyloplast envelope. J. Exp. Bot. 2007, 58, 1321-1332. [CrossRef] [PubMed]

156. Cakir, B.; Shiraishi, S.; Tuncel, A.; Matsusaka, H.; Satoh, R.; Singh, S.; Crofts, N.; Hosaka, Y.; Fujita, N.; Hwang, S.-K.; et al. Analysis of the rice ADPglucose transporter (OsBT1) indicates the presence of regulatory processes in the amyloplast stroma that control ADPglucose flux into starch. Plant Physiol. 2016, 170, 1271-1283. [CrossRef] [PubMed]

157. Beckles, D.M.; Smith, A.M.; ap Rees, T. A cytosolic ADP-glucose pyrophosphorylase is a feature of graminaceous endosperms, but not of other starch-storing organs. Plant Physiol. 2001, 125, 818-827. [CrossRef] [PubMed]

158. Gross, P.; ap Rees, T. Alkaline inorganic pyrophosphatase and starch synthesis in amyloplasts. Planta 1986, 167, 140-145. [CrossRef] [PubMed]

159. Tiessen, A.; Nerlich, A.; Faix, B.; Hümmer, C.; Fox, S.; Trafford, K.; Weber, H.; Weschke, W.; Geigenberger, P. Subcellular analysis of starch metabolism in developing barley seeds using a non-aqueous fractionation method. J. Exp. Bot. 2012, 63, 2071-2087. [CrossRef] [PubMed]

160. Fu, Y.; Ballicora, M.A.; Leykam, J.F.; Preiss, J. Mechanism of reductive activation of potato tuber ADP-glucose pyrophosphorylase. J. Biol. Chem. 1998, 273, 25045-25052. [CrossRef] [PubMed]

161. Tiessen, A.; Hendriks, J.H.M.; Stitt, M.; Branscheid, A.; Gibon, Y.; Farré, E.M.; Geigenberger, P. Starch synthesis in potato tubers is regulated by post-translational redox modification of ADP-glucose pyrophosphorylase. Am. Soc. Plant Biol. 2002, 14, 2191-2213. [CrossRef]

162. Gómez-Casati, D.F.; Iglesias, A.A. ADP-glucose pyrophosphorylase from wheat endosperm. Purification and characterization of an enzyme with novel regulatory properties. Planta 2002, 214, 428-434. [CrossRef] [PubMed]

163. Kleczkowski, L.; Villand, P.; Lüthi, E.; Olsen, O.; Preiss, J. Insensitivity of barley endosperm ADP-glucose pyrophosphorylase to 3-phosphoglycerate and orthophosphate regulation. Plant Physiol. 1993, 101, 179-186. [CrossRef] [PubMed]

164. Geigenberger, P. Regulation of Starch Biosynthesis in Response to a Fluctuating Environment. Plant Physiol. 2011, 155, 1566-1577. [CrossRef] [PubMed]

165. Tuncel, A.; Okita, T.W. Improving starch yield in cereals by over-expression of ADPglucose pyrophosphorylase: Expectations and unanticipated outcomes. Plant Sci. 2013, 211, 52-60. [CrossRef] [PubMed]

166. Hannah, L.C.; Futch, B.; Bing, J.; Shaw, J.R.; Boehlein, S.; Stewart, J.D.; Beiriger, R.; Georgelis, N.; Greene, T. A shrunken-2 Transgene Increases Maize Yield by Acting in Maternal Tissues to Increase the Frequency of Seed Development. Plant Cell 2012, 24, 2352-2363. [CrossRef] [PubMed]

167. Smidansky, E.D.; Meyer, F.D.; Blakeslee, B.; Weglarz, T.E.; Greene, T.W.; Giroux, M.J. Expression of a modified ADP-glucose pyrophosphorylase large subunit in wheat seeds stimulates photosynthesis and carbon metabolism. Planta 2007, 225, 965-976. [CrossRef] [PubMed]

168. Smidansky, E.D.; Martin, J.M.; Hannah, L.C.; Fischer, A.M.; Giroux, M.J. Seed yield and plant biomass increases in rice are conferred by deregulation of endosperm ADP-glucose pyrophosphorylase. Planta 2003, 216, 656-664. [CrossRef] [PubMed]

169. Smidansky, E.; Clancy, M.; Meyer, F.; Lanning, S.; Blake, N.; Talbert, L.; Giroux, M. Enhanced ADP-glucose pyrophosphorylase activity in wheat endosperm increases seed yield. J. Plant Physiol. Pathol. 2002, 99, 1724-1729. [CrossRef] [PubMed]

170. Meyer, F.; Smidansky, E.; Beecher, B.; Greene, T.; Giroux, M. The maize Sh2r6hs ADP-glucose pyrophosphorylase (AGP) large subunit confers enhanced AGP properties in transgenic wheat (Triticum aestivum). Plant Sci. 2004, 167, 899-911. [CrossRef]

171. Oiestad, A.J.; Martin, J.M.; Giroux, M.J. Overexpression of ADP-glucose pyrophosphorylase in both leaf and seed tissue synergistically increase biomass and seed number in rice (Oryza sativa ssp. japonica). Funct. Plant Biol. 2016, 43, 1194-1204. [CrossRef] 
172. Greene, T.W.; Kavakli, I.H.; Kahn, M.L.; Okita, T.W. Generation of up-regulated allosteric variants of potato ADP-glucose pyrophosphorylase by reversion genetics. Proc. Natl. Acad. Sci. USA 1998, 95, 10322-10327. [CrossRef] [PubMed]

173. Salamone, P.R.; Kavakli, I.H.; Slattery, C.J.; Okita, T.W. Directed molecular evolution of ADP-glucose pyrophosphorylase. Proc. Natl. Acad. Sci. USA 2002, 99, 1070-1075. [CrossRef] [PubMed]

174. Halil Kavakli, I.; Kato, C.; Choi, S.B.; Kim, K.H.; Salamone, P.R.; Ito, H.; Okita, T.W. Generation, characterization, and heterologous expression of wild-type and up-regulated forms of Arabidopsis thaliana leaf ADP-glucose pyrophosphorylase. Planta 2002, 215, 430-439. [CrossRef] [PubMed]

175. Recondo, E.; Leloir, L.F. Adenosine diphosphate glucose and starch synthesis. Biochem. Biophys. Res. Commun. 1961, 6, 85-88. [CrossRef]

176. Cuesta-Seijo, J.A.; Nielsen, M.M.; Ruzanski, C.; Krucewicz, K.; Beeren, S.R.; Rydhal, M.G.; Yoshimura, Y.; Striebeck, A.; Motawia, M.S.; Willats, W.G.T.; et al. In vitro biochemical characterization of all barley endosperm starch synthases. Front. Plant Sci. 2016, 6, 1-17. [CrossRef] [PubMed]

177. Furukawa, K.; Tagaya, M.; Tanizawa, K.; Fukui, T. Role of the conserved Lys-X-Gly-Gly sequence at the ADP-glucose-binding site in Escherichia coli glycogen synthase. J. Biol. Chem. 1993, 268, 23837-23842. [PubMed]

178. Furukawa, K.; Tagaya, M.; Preiss, J.; Fukui, Y. Identification of lysine 15 at the active site in E. coli glycogen synthase. J. Biol. Chem. 1990, 265, 2086-2090. [PubMed]

179. Busi, M.; Palapoli, N.; Valdez, H.; Fornasari, M.; Wayllace, N.; Gomez-Casati, D.; Parisi, G.; Ugalde, R. Functional and structural characterization of the catalytic domain of the starch synthase III from Arabidopsis thaliana. Proteins 2008, 70, 31-40. [CrossRef] [PubMed]

180. Gao, M.; Wanat, J.; Stinard, P.S.; James, M.G.; Myers, A.M. Characterization of DULL1, a maize gene coding for a novel starch synthase. Plant Cell 1998, 10, 399-412. [CrossRef] [PubMed]

181. De Fekete, M.; Leloir, L.; Cardini, C. Mechanism of starch biosynthesis. Nature 1960, 187, 918-919. [CrossRef]

182. Nelson, O.E.; Rines, H.W. The enzymatic deficiency in the waxy mutant of maize. Biochem. Biophys. Res. Commun. 1962, 9, 297-300. [CrossRef]

183. Brink, R.; MacGillivray, J. Segregation for the waxy character in maize pollen and differential development of the male gametophyte. Am. J. Bot. 1924, 11, 465-469. [CrossRef]

184. Denyer, K.; Waite, D.; Motawia, S.; Møller, B.L.; Smith, A.M. Granule-bound starch synthase I in isolated starch granules elongates malto-oligosaccharides processively. Biochem. J. 1999, 340, 183-191. [CrossRef] [PubMed]

185. Takeda, Y.; Maruta, N.; Hizukuri, S. Structures of amylose subfractions with different molecular sizes. Carbohydr. Res. 1992, 226, 279-285. [CrossRef]

186. Hanashiro, I.; Itoh, K.; Kuratomi, Y.; Yamazaki, M.; Igarashi, T.; Matsugasako, J.I.; Takeda, Y. Granule-bound starch synthase I is responsible for biosynthesis of extra-long unit chains of amylopectin in rice. Plant Cell Physiol. 2008, 49, 925-933. [CrossRef] [PubMed]

187. Fujita, N.; Hasegawa, H.; Taira, T. The isolation and characterization of a waxy mutant of diploid wheat (Triticum monococcum L.). Plant Sci. 2001, 160, 595-602. [CrossRef]

188. Tester, R.F.; Morrison, W.R. Swelling and gelatinization of cereal starches. III. Some properties of waxy and normal nonwaxy barley starches. Cereal Chem. 1992, 69, 654-658.

189. Yamanaka, S.; Nakamura, I.; Watanabe, K.N.; Sato, Y.I. Identification of SNPs in the waxy gene among glutinous rice cultivars and their evolutionary significance during the domestication process of rice. Theor. Appl. Genet. 2004, 108, 1200-1204. [CrossRef] [PubMed]

190. Tsai, C.Y. The function of the Waxy locus in starch synthesis in maize endosperm. Biochem. Genet. 1974, 11, 83-96. [CrossRef] [PubMed]

191. Shure, M.; Wessler, S.; Fedoroff, N. Molecular identification and isolation of the Waxy locus in maize. Cell 1983, 35, 225-233. [CrossRef]

192. Bettge, A.D.; Giroux, M.J.; Morris, C.F. Susceptibility of waxy starch granules to mechanical damage. Cereal Chem. 2000, 77, 750-753. [CrossRef]

193. Yeh, J.Y.; Garwood, D.L.; Shannon, J.C. Characterization of Starch from Maize Endosperm Mutants. Starch Stärke 1981, 33, 222-230. [CrossRef] 
194. Ahuja, G.; Jaiswal, S.; Hucl, P.; Chibbar, R.N. Genome-specific granule-bound starch synthase i (GBSSI) influences starch biochemical and functional characteristics in near-isogenic wheat (Triticum aestivum $\mathrm{L}$.) Lines. J. Agric. Food Chem. 2013, 61, 12129-12138. [CrossRef] [PubMed]

195. Cooke, D.; Gidley, M.J. Loss of crystalline and molecular order during starch gelatinisation: Origin of the enthalpic transition. Carbohydr. Res. 1992, 227, 103-112. [CrossRef]

196. Bogracheva, T.Y.; Cairns, P.; Noel, T.R.; Hulleman, S.; Wang, T.L.; Morris, V.J.; Ring, S.G.; Hedley, C.L. Effect of mutant genes at the $\mathrm{r}, \mathrm{rb}$, rug3, rug4, rug5 and lam loci on the granular structure and physico-chemical properties of pea seed starch. Carbohydr. Polym. 1999, 39, 303-314. [CrossRef]

197. Inouchi, N.; Glover, D.V.; Fuwa, H. Chain Length Distribution of Amylopectins of Several Single Mutants and the Normal Counterpart, and Sugary-1 Phytoglycogen in Maize (Zea mays L.). Starch Stärke 1987, 39, 259-266. [CrossRef]

198. Nakamura, T.; Vrinten, P.; Hayakawa, K.; Ikeda, J. Characterization of a granule-bound starch synthase isoform found in the pericarp of wheat. Plant Physiol. 1998, 118, 451-459. [CrossRef] [PubMed]

199. Fujita, N.; Taira, T. A 56-kDa protein is a novel granule-bound starch synthase existing in the pericarps, aleurone layers, and embryos of immature seed in diploid wheat (Triticum monococcum L.). Planta 1998, 207, 125-132. [CrossRef] [PubMed]

200. Vrinten, P.L.; Nakamura, T. Wheat granule-bound starch synthase I and II are encoded by separate genes that are expressed in different tissues. Plant Physiol. 2000, 122, 255-264. [CrossRef] [PubMed]

201. Denyer, K.; Sidebottom, C.; Hylton, C.M.; Smith, A.M. Soluble isoforms of starch synthase and starch-branching enzyme also occur within starch granules in developing pea embryos. Plant J. 1993, 4, 191-198. [CrossRef] [PubMed]

202. Mu-forster, C.; Huang, R.; Powers, J.R.; Harriman, R.W.; Knight, M.; Singletary, C.W.; Keeling, P.; Wasserman, B.P. Physical Association. Plant Physiol. 1995, 111, 821-829. [CrossRef]

203. Li, H.; Xiao, Q.; Zhang, C.; Du, J.; Li, X.; Huang, H.; Wei, B.; Li, Y.; Yu, G.; Liu, H.; et al. Identification and characterization of transcription factor ZmEREB94 involved in starch synthesis in maize. J. Plant Physiol. 2017, 216, 11-16. [CrossRef] [PubMed]

204. Edwards, A.; Borthakur, A.; Bornemann, S.; Venail, J.; Denyer, K.; Waite, D.; Fulton, D.; Smith, A.; Martin, C. Specificity of starch synthase isoforms from potato. Eur. J. Biochem. 1999, 266, 724-736. [CrossRef] [PubMed]

205. Denyer, K.; Clarke, B.; Hylton, C.; Tatge, H.; Smith, A.M. The elongation of amylose and amylopectin chains in isolated starch granules. Plant J. 1996, 10, 1135-1143. [CrossRef]

206. Clarke, B.R.; Denyer, K.; Jenner, C.F.; Smith, A.M. The relationship between the rate of starch synthesis, the adenosine $5^{\prime}$-diphosphoglucose concentration and the amylose content of starch in developing pea embryos. Planta 1999, 209, 324-329. [CrossRef] [PubMed]

207. Liu, D.R.; Huang, W.X.; Cai, X.L. Oligomerization of rice granule-bound starch synthase 1 modulates its activity regulation. Plant Sci. 2013, 210, 141-150. [CrossRef] [PubMed]

208. Grimaud, F.; Rogniaux, H.; James, M.G.; Myers, A.M.; Planchot, V. Proteome and phosphoproteome analysis of starch granule-associated proteins from normal maize and mutants affected in starch biosynthesis. J. Exp. Bot. 2008, 59, 3395-3406. [CrossRef] [PubMed]

209. Seung, D.; Soyk, S.; Coiro, M.; Maier, B.A.; Eicke, S.; Zeeman, S.C. PROTEIN TARGETING TO STARCH Is Required for Localising GRANULE-BOUND STARCH SYNTHASE to Starch Granules and for Normal Amylose Synthesis in Arabidopsis. PLoS Biol. 2015, 13, 1-29. [CrossRef] [PubMed]

210. Commuri, P.D.; Keeling, P.L. Chain-length specificities of maize starch synthase I enzyme: Studies of glucan affinity and catalytic properties. Plant J. 2001, 25, 475-486. [CrossRef] [PubMed]

211. Fujita, N.; Yoshida, M.; Asakura, N.; Ohdan, T.; Miyao, A.; Hirochika, H.; Nakamura, Y. Function and Characterization of Starch Synthase I Using Mutants in Rice. Plant Physiol. 2006, 140, 1070-1084. [CrossRef] [PubMed]

212. Imparl-Radosevich, J.M.; Li, P.; Zhang, L.; McKean, A.L.; Keeling, P.L.; Guan, H. Purification and characterization of maize starch synthase I and its truncated forms. Arch. Biochem. Biophys. 1998, 353, 64-72. [CrossRef] [PubMed]

213. Wilkens, C.; Cuesta-Seijo, J.; Palcic, M.; Svensson, B. Selectivity of the surface binding site (SBS) on barley starch synthase I. Biologia (Bratisl.) 2014, 69, 1118-1121. [CrossRef]

214. Mcmaugh, S.J.; Thistleton, J.L.; Anschaw, E.; Luo, J.; Konik-Rose, C.; Wang, H.; Huang, M.; Larroque, O.; Regina, A.; Jobling, S.A.; et al. Suppression of starch synthase I expression affects the granule morphology 
and granule size and fine structure of starch in wheat endosperm. J. Exp. Bot. 2014, 65, 2189-2201. [CrossRef] [PubMed]

215. Zhang, X.; Colleoni, C.; Ratushna, V.; Sirghie-colleoni, M.; James, M.; Myers, A. Molecular characterization demonstrates that the Zea mays gene sugary2 codes for the starch synthase isoform SSIIa. Plant Mol. Biol. 2004, 54, 865-879. [CrossRef] [PubMed]

216. Imparl-Radosevich, J.; Gameon, J.; McKean, A.; Wetterberg, D.; Keeling, P.; Guan, H. Understanding catalytic properties and functions of maize starch synthase isozymes. J. Appl. Glycosci. 2003, 50, 177-182. [CrossRef]

217. Cao, H.; Imparl-Radosevich, J.; Guan, H.; Keeling, P.L.; James, M.G.; Myers, A.M. Identification of the soluble starch synthase activities of maize endosperm. Plant Physiol. 1999, 120, 205-216. [CrossRef] [PubMed]

218. Waters, D.L.E.; Henry, R.J.; Reinke, R.F.; Fitzgerald, M.A. Gelatinization temperature of rice explained by polymorphisms in starch synthase. Plant Biotechnol. J. 2006, 4, 115-122. [CrossRef] [PubMed]

219. Nakamura, Y.; Sakurai, A.; Inaba, Y.; Kimura, K.; Iwasawa, N.; Nagamine, T. The fine structure of amylopectin in endosperm from Asian cultivated rice can be largely classified into two classes. Starch/Staerke 2002, 54, 117-131. [CrossRef]

220. Nakamura, Y.; Francisco, B., Jr.; Hosaka, Y.; Satoh, A.; Sawada, T.; Kubo, A.; Fujita, N. Essential amino acids of starch synthase IIa differentiate amylopectin structure and starch quality between japonica and indica rice cultivars. Starch Stärke 2005, 58, 213-227.

221. Umemoto, T.; Aoki, N. Single-nucleotide polymorphisms in rice starch synthase IIa that alter starch gelatinisation and starch association of the enzyme. Funct. Plant Biol. 2005, 32, 763-768. [CrossRef]

222. Umemoto, T.; Aoki, N.; Lin, H.; Nakamura, Y.; Inouchi, N.; Sato, Y.; Yano, M.; Hirabayashi, H.; Maruyama, S. Natural variation in rice starch synthase IIa affects enzyme and starch properties. Funct. Plant Biol. 2004, 31, 671-684. [CrossRef]

223. Umemoto, T.; Terashima, K.; Nakamura, Y.; Satoh, H. Differences in Amylopectin Structure between Two Rice Varieties in Relation to the Effects of Temperature during Grain-Filling. Starch Stärke 1999, 51, 58-62. [CrossRef]

224. Umemoto, T.; Yano, M.; Satoh, H.; Shomura, A.; Nakamura, Y. Mapping of a gene responsible for the difference in amylopectin structure between japonica-type and indica-type rice varieties. Theor. Appl. Genet. 2002, 104, 1-8. [CrossRef] [PubMed]

225. Morell, M.K.; Kosar-Hashemi, B.; Cmiel, M.; Samuel, M.S.; Chandler, P.; Rahman, S.; Buleon, A.; Batey, I.L.; Li, Z. Barley sex6 mutants lack starch synthase lla activity and contain a starch with novel properties. Plant J. 2003, 34, 173-185. [CrossRef] [PubMed]

226. Hennen-Bierwagen, T.A.; Liu, F.; Marsh, R.S.; Kim, S.; Gan, Q.; Tetlow, I.J.; Emes, M.J.; James, M.G.; Myers, A.M. Starch Biosynthetic Enzymes from Developing Maize Endosperm Associate in Multisubunit Complexes. Plant Physiol. 2008, 146, 1892-1908. [CrossRef] [PubMed]

227. Hennen-Bierwagen, T.A.; Lin, Q.; Grimaud, F.; Planchot, V.; Keeling, P.L.; James, M.G.; Myers, A.M. Proteins from Multiple Metabolic Pathways Associate with Starch Biosynthetic Enzymes in High Molecular Weight Complexes: A Model for Regulation of Carbon Allocation in Maize Amyloplasts. Plant Physiol. 2009, 149, 1541-1559. [CrossRef] [PubMed]

228. Tetlow, I.; Liu, F.; Emes, M. Protein-protein interactions during starch biosynthesis. In Starch Metabolism and Structure; Springer: Tokyo, Japan, 2015; pp. 291-313.

229. Yamamori, M.; Fujita, S.; Hayakawa, K.; Matsuki, J.; Yasui, T. Genetic elimination of a starch granule protein, SGP-1, of wheat generates an altered starch with apparent high amylose. Theor. Appl. Genet. 2000, 101, 21-29. [CrossRef]

230. Luo, J.; Ahmed, R.; Kosar-Hashemi, B.; Larroque, O.; Butardo, V.M.; Tanner, G.J.; Colgrave, M.L.; Upadhyaya, N.M.; Tetlow, I.J.; Emes, M.J.; et al. The different effects of starch synthase IIa mutations or variation on endosperm amylose content of barley, wheat and rice are determined by the distribution of starch synthase I and starch branching enzyme Ilb between the starch granule and amyloplast. Theor. Appl. Genet. 2015, 128, 1407-1419. [CrossRef] [PubMed]

231. Liu, F.; Romanova, N.; Lee, E.A.; Ahmed, R.; Evans, M.; Gilbert, E.P.; Morell, M.K.; Emes, M.J.; Tetlow, I.J. Glucan affinity of starch synthase Ila determines binding of starch synthase I and starch-branching enzyme IIb to starch granules. Biochem. J. 2012, 448, 373-387. [CrossRef] [PubMed] 
232. Li, Z.; Li, D.; Du, X.; Wang, H.; Larroque, O.; Jenkins, C.L.D.; Jobling, S.A.; Morell, M.K. The barley amo1 locus is tightly linked to the starch synthase IIIa gene and negatively regulates expression of granule-bound starch synthetic genes. J. Exp. Bot. 2011, 62, 5217-5231. [CrossRef] [PubMed]

233. Hirose, T.; Terao, T. A comprehensive expression analysis of the starch synthase gene family in rice (Oryza sativa L.). Planta 2004, 220, 9-16. [CrossRef] [PubMed]

234. Dian, W.; Jiang, H.; Wu, P. Evolution and expression analysis of starch synthase III and IV in rice. J. Exp. Bot. 2005, 56, 623-632. [CrossRef] [PubMed]

235. Fujita, N.; Yoshida, M.; Kondo, T.; Saito, K.; Utsumi, Y.; Tokunaga, T.; Nishi, A.; Satoh, H.; Park, J.-H.; Jane, J.-L.; et al. Characterization of SSIIIa-Deficient Mutants of Rice: The Function of SSIIIa and Pleiotropic Effects by SSIIIa Deficiency in the Rice Endosperm. Plant Physiol. 2007, 144, 2009-2023. [CrossRef] [PubMed]

236. Lin, Q.; Huang, B.; Zhang, M.; Zhang, X.; Rivenbark, J.; Lappe, R.L.; James, M.G.; Myers, A.M.; Hennen-Bierwagen, T.A. Functional Interactions between Starch Synthase III and Isoamylase-Type Starch-Debranching Enzyme in Maize Endosperm. Plant Physiol. 2012, 158, 679-692. [CrossRef] [PubMed]

237. Mangelsdorf, P.C. The Inheritance of Amylaceous Sugary Endosperm and Its Derivatives in Maize. Genetics 1947, 32, 448-458. [PubMed]

238. Inouchi, N.; Glover, D.V.; Takaya, T.; Fuwa, H. Development Changes in Fine Structure of Starches of Several Endosperm Mutants of Maize. Starch Stärke 1983, 35, 371-376. [CrossRef]

239. Ryoo, N.; Yu, C.; Park, C.S.; Baik, M.Y.; Park, I.M.; Cho, M.H.; Bhoo, S.H.; An, G.; Hahn, T.R.; Jeon, J.S. Knockout of a starch synthase gene OsSSIIIa/Flo5 causes white-core floury endosperm in rice (Oryza sativa L.). Plant Cell Rep. 2007, 26, 1083-1095. [CrossRef] [PubMed]

240. Cao, H.; James, M.; Myers, A. Purification and characterization of soluble starch synthases from maize endosperm. Arch. Biochem. Biophys. 2000, 373, 135-146. [CrossRef] [PubMed]

241. James, M.G.; Denyer, K.; Myers, A.M. Starch synthesis in the cereal endosperm. Curr. Opin. Plant Biol. 2003, 6, 215-222. [CrossRef]

242. Szydlowski, N.; Ragel, P.; Raynaud, S.; Lucas, M.M.; Roldan, I.; Montero, M.; Munoz, F.J.; Ovecka, M.; Bahaji, A.; Planchot, V.; et al. Starch Granule Initiation in Arabidopsis Requires the Presence of Either Class IV or Class III Starch Synthases. Plant Cell Online 2009, 21, 2443-2457. [CrossRef] [PubMed]

243. Crofts, N.; Abe, K.; Aihara, S.; Itoh, R.; Nakamura, Y.; Itoh, K.; Fujita, N. Lack of starch synthase IIIa and high expression of granule-bound starch synthase I synergistically increase the apparent amylose content in rice endosperm. Plant Sci. 2012, 193-194, 62-69. [CrossRef] [PubMed]

244. Boyer, C.D.; Preiss, J. Evidence for independent genetic control of the multiple forms of maize endosperm branching enzymes and starch synthases. Plant Physiol. 1981, 67, 1141-1145. [CrossRef] [PubMed]

245. Wang, Y.J.; White, P.; Pollak, L.; Jane, J. Characterization of starch structures of 17 maize endosperm mutant genotypes with Oh43 inbred line background. Cereal Chem. 1993, 70, 171-179.

246. Valdez, H.A.; Busi, M.V.; Wayllace, N.Z.; Parisi, G.; Ugalde, R.A.; Gomez-casati, D.F. Role of the $\mathrm{N}$-Terminal starch-binding domains in the kinetic properties of Starch Synthase III from Arabidopsis thaliana. Biochemistry 2008, 47, 3026-3032. [CrossRef] [PubMed]

247. Wayllace, N.Z.; Valdez, H.A.; Ugalde, R.A.; Busi, M.V.; Gomez-Casati, D.F. The starch-binding capacity of the noncatalytic SBD2 region and the interaction between the $\mathrm{N}$ - and C-terminal domains are involved in the modulation of the activity of starch synthase III from Arabidopsis thaliana: Enzymes and catalysis. FEBS J. 2010, 277, 428-440. [CrossRef] [PubMed]

248. Leterrier, M.; Holappa, L.D.; Broglie, K.E.; Beckles, D.M. Cloning, characterisation and comparative analysis of a starch synthase IV gene in wheat: Functional and evolutionary implications. BMC Plant Biol. 2008, 8, 98. [CrossRef] [PubMed]

249. Roldán, I.; Wattebled, F.; Mercedes Lucas, M.; Delvallé, D.; Planchot, V.; Jiménez, S.; Pérez, R.; Ball, S.; D'Hulst, C.; Mérida, Á. The phenotype of soluble starch synthase IV defective mutants of Arabidopsis thaliana suggests a novel function of elongation enzymes in the control of starch granule formation. Plant J. 2007, 49, 492-504. [CrossRef] [PubMed]

250. Crumpton-Taylor, M.; Grandison, S.; Png, K.M.Y.; Bushby, A.J.; Smith, A.M. Control of Starch Granule Numbers in Arabidopsis Chloroplasts. Plant Physiol. 2012, 158, 905-916. [CrossRef] [PubMed]

251. Ragel, P.; Streb, S.; Feil, R.; Sahrawy, M.; Annunziata, M.G.; Lunn, J.E.; Zeeman, S.; Merida, A. Loss of Starch Granule Initiation Has a Deleterious Effect on the Growth of Arabidopsis Plants Due to an Accumulation of ADP-Glucose. Plant Physiol. 2013, 163, 75-85. [CrossRef] [PubMed] 
252. D'Hulst, C.; Mérida, Á. The priming of storage glucan synthesis from bacteria to plants: Current knowledge and new developments. New Phytol. 2010, 188, 13-21. [CrossRef] [PubMed]

253. Malinova, I.; Mahlow, S.; Alseekh, S.; Orawetz, T.; Fernie, A.R.; Baumann, O.; Steup, M.; Fettke, J. Double Knockout Mutants of Arabidopsis Grown under Normal Conditions Reveal that the Plastidial Phosphorylase Isozyme Participates in Transitory Starch Metabolism. Plant Physiol. 2014, 164, 907-921. [CrossRef] [PubMed]

254. Malinova, I.; Alseekh, S.; Feil, R.; Fernie, A.R.; Baumann, O.; Schöttler, M.A.; Lunn, J.E.; Fettke, J. Starch Synthase 4 and Plastidal Phosphorylase Differentially Affect Starch Granule Number and Morphology. Plant Physiol. 2017, 174, 73-85. [CrossRef] [PubMed]

255. Toyosawa, Y.; Kawagoe, Y.; Matsushima, R.; Crofts, N.; Ogawa, M.; Fukuda, M.; Kumamaru, T.; Okazaki, Y.; Kusano, M.; Saito, K.; et al. Deficiency of Starch Synthase IIIa and IVb Alters Starch Granule Morphology from Polyhedral to Spherical in Rice Endosperm. Plant Physiol. 2016, 170, 1255-1270. [CrossRef] [PubMed]

256. Gámez-Arjona, F.M.; Raynaud, S.; Ragel, P.; Mérida, Á. Starch synthase 4 is located in the thylakoid membrane and interacts with plastoglobule-associated proteins in Arabidopsis. Plant J. 2014, 80, 305-316. [CrossRef] [PubMed]

257. Raynaud, S.; Ragel, P.; Rojas, T.; Mérida, Á. The N-terminal part of Arabidopsis thaliana starch synthase 4 determines the localization and activity of the enzyme. J. Biol. Chem. 2016, 291, 10759-10771. [CrossRef] [PubMed]

258. Yun, M.S.; Kawagoe, Y. Septum formation in amyloplasts produces compound granules in the rice endosperm and is regulated by plastid division proteins. Plant Cell Physiol. 2010, 51, 1469-1479. [CrossRef] [PubMed]

259. Drummond, G.S.; Smith, E.E.; Whelan, W.J. Purification and Properties of Potato: $\alpha-1,4-G l u c a n$ 6-Glycosyltransferase (Q-Enzyme). Eur. J. Biochem. 1972, 26, 168-176. [CrossRef] [PubMed]

260. Hawker, J.S.; Ozbun, J.L.; Ozaki, H.; Greenberg, E.; Preiss, J. Interaction of spinach leaf adenosine diphosphate glucose $\alpha$-1,4-glucan $\alpha$-4-glucosyl transferase and $\alpha$-1,4-glucan, $\alpha$-1,4-glucan-6-glycosyl transferase in synthesis of branched $\alpha$-glucan. Arch. Biochem. Biophys. 1974, 160, 530-551. [CrossRef]

261. Brust, H.; Lehmann, T.; D'Hulst, C.; Fettke, J. Analysis of the functional interaction of arabidopsis starch synthase and branching enzyme isoforms reveals that the cooperative action of SSI and BEs results in glucans with polymodal chain length distribution similar to amylopectin. PLoS ONE 2014, 9. [CrossRef] [PubMed]

262. Li, C.; Wu, A.C.; Go, R.M.; Malouf, J.; Turner, M.S.; Malde, A.K.; Mark, A.E.; Gilbert, R.G. The characterization of modified starch branching enzymes: Toward the control of starch chain-length distributions. PLoS ONE 2015, 10, e0125507. [CrossRef] [PubMed]

263. Pfister, B.; Lu, K.-J.; Eicke, S.; Feil, R.; Lunn, J.E.; Streb, S.; Zeeman, S.C. Genetic Evidence That Chain Length and Branch Point Distributions Are Linked Determinants of Starch Granule Formation in Arabidopsis. Plant Physiol. 2014, 165, 1457-1474. [CrossRef] [PubMed]

264. O'Sullivan, A.; Perez, S. The relationship between internal chain length of amylopectin and crystallinity. Biopolymers 1999, 50, 381-390. [CrossRef]

265. Boyer, L.; Roussel, X.; Courseaux, A.; Ndjindji, O.M.; Lancelon-Pin, C.; Putaux, J.L.; Tetlow, I.J.; Emes, M.J.; Pontoire, B.; D'Hulst, C.; et al. Expression of Escherichia coli glycogen branching enzyme in an Arabidopsis mutant devoid of endogenous starch branching enzymes induces the synthesis of starch-like polyglucans. Plant Cell Environ. 2016, 39, 1432-1447. [CrossRef] [PubMed]

266. Lu, K.-J.; Streb, S.; Meier, F.; Pfister, B.; Zeeman, S.C. Molecular genetic analysis of glucan branching enzymes from plants and bacteria in Arabidopsis reveals marked differences in their functions and capacity to mediate starch granule formation. Plant Physiol. 2015, 169, 1638-1655. [CrossRef] [PubMed]

267. Jespersen, H.M.; Ann MacGregor, E.; Henrissat, B.; Sierks, M.R.; Svensson, B. Starch- and glycogen-debranching and branching enzymes: Prediction of structural features of the catalytic $(\beta / \alpha) 8$-barrel domain and evolutionary relationship to other amylolytic enzymes. J. Protein Chem. 1993, 12, 791-805. [CrossRef] [PubMed]

268. Borovsky, D.; Smith, E.E.; Whelan, W.J. On The Mechanism of Amylose Branching by Potato Q-Enzyme. Eur. J. Biochem. 1976, 62, 307-312. [CrossRef] [PubMed]

269. Borovsky, D.; Smith, E.E.; Whelan, W.J.; French, D.; Kikumoto, S. The mechanism of Q-enzyme action and its influence on the structure of amylopectin. Arch. Biochem. Biophys. 1979, 198, 627-631. [CrossRef]

270. Abad, M.C.; Binderup, K.; Rios-Steiner, J.; Arni, R.K.; Preiss, J.; Geiger, J.H. The x-ray crystallographic structure of Escherichia coli branching enzyme. J. Biol. Chem. 2002, 277, 42164-42170. [CrossRef] [PubMed] 
271. Devillers, C.H.; Piper, M.E.; Ballicora, M.A.; Preiss, J. Characterization of the branching patterns of glycogen branching enzyme truncated on the N-terminus. Arch. Biochem. Biophys. 2003, 418, 34-38. [CrossRef]

272. Palomo, M.; Pijning, T.; Booiman, T.; Dobruchowska, J.M.; Van Der Vlist, J.; Kralj, S.; Planas, A.; Loos, K.; Kamerling, J.P.; Dijkstra, B.W.; et al. Thermus thermophilus glycoside hydrolase family 57 branching enzyme: Crystal structure, mechanism of action, and products formed. J. Biol. Chem. 2011, 286, 3520-3530. [CrossRef] [PubMed]

273. Kuriki, T.; Stewart, D.C.; Chem, J.B.; Kuriki, T.; Stewart, D.C.; Preiss, J. Construction of Chimeric Enzymes out of Maize Endosperm Branching Enzymes I and II: Activity and Properties. J. Biol. Chem. 1997, 272, 28999-29004. [CrossRef] [PubMed]

274. Tetlow, I.J.; Emes, M.J. A review of starch-branching enzymes and their role in amylopectin biosynthesis. IUBMB Life 2014, 66, 546-558. [CrossRef] [PubMed]

275. Blauth, S.L.; Kim, K.N.; Klucinec, J.; Shannon, J.C.; Thompson, D.; Guiltinan, M. Identification of mutator insertional mutants of starch-branching enzyme 1 (sbe1) in Zea mays L. Plant Mol. Biol. 2002, 48, 287-297. [CrossRef] [PubMed]

276. Wolfe, K.H.; Gouy, M.; Yang, Y.W.; Sharp, P.M.; Li, W.H. Date of the monocot-dicot divergence estimated from chloroplast DNA sequence data. Proc. Natl. Acad. Sci. USA 1989, 86, 6201-6205. [CrossRef] [PubMed]

277. Gao, M.; Fisher, D.K.; Kim, K.-N.; Shannon, J.C.; Guiltinan, M.J. Evolutionary conservation and expression patterns of maize starch branching enzyme I and Ilb genes suggests isoform specialization. Plant Mol. Biol. 1996, 30, 1223-1232. [CrossRef] [PubMed]

278. Yamanouchi, H.; Nakamura, Y. Organ specificity of isoforms of starch branching enzyme (Q-enzyme) in rice. Plant Cell Physiol. 1992, 33, 985-991. [CrossRef]

279. Morell, M.K.; Blennow, A.; Kosar-Hashemi, B.; Samuel, M.S. Differential Expression and Properties of Starch Branching Enzyme Isoforms in Developing Wheat Endosperm. Plant Physiol. 1997, 113, 201-208. [CrossRef] [PubMed]

280. Rahman, S. Comparison of Starch-Branching Enzyme Genes Reveals Evolutionary Relationships Among Isoforms. Characterization of a Gene for Starch-Branching Enzyme IIa from the Wheat D Genome Donor Aegilops tauschii. Plant Physiol. 2001, 125, 1314-1324. [CrossRef] [PubMed]

281. Guan, H.; Li, P.; Imparl-Radosevich, J.; Preiss, J.; Keeling, P. Comparing the properties of Escherichia coli branching enzyme and maize branching enzyme. Arch. Biochem. Biophys. 1997, 342, 92-98. [CrossRef] [PubMed]

282. Takeda, Y.; Guan, H.P.; Preiss, J. Branching of amylose by the branching isoenzymes of maize endosperm. Carbohydr. Res. 1993, 240, 253-263. [CrossRef]

283. Guan, H.P.; Preiss, J. Differentiation of the Properties of the Branching Isozymes from Maize (Zea mays). Plant Physiol. 1993, 102, 1269-1273. [CrossRef] [PubMed]

284. Nakamura, Y.; Utsumi, Y.; Sawada, T.; Aihara, S.; Utsumi, C.; Yoshida, M.; Kitamura, S. Characterization of the reactions of starch branching enzymes from rice endosperm. Plant Cell Physiol. 2010, 51, 776-794. [CrossRef] [PubMed]

285. Regina, A.; Kosar-Hashemi, B.; Li, Z.; Rampling, L.; Cmiel, M.; Gianibelli, M.C.; Konik-Rose, C.; Larroque, O.; Rahman, S.; Morell, M.K. Multiple isoforms of starch branching enzyme-I in wheat: Lack of the major SBE-I isoform does not alter starch phenotype. Funct. Plant Biol. 2004, 31, 591-601. [CrossRef]

286. Satoh, H.; Nishi, A.; Yamashita, K.; Takemoto, Y.; Tanaka, Y.; Hosaka, Y.; Sakurai, A.; Fujita, N.; Nakamura, Y. Starch-branching enzyme I-deficient mutation specifically affects the structure and properties of starch in rice endosperm. Plant Physiol. 2003, 133, 1111-1121. [CrossRef] [PubMed]

287. Yao, Y.; Thompson, D.B.; Guiltinan, M.J. Maize starch-branching enzyme isoforms and amylopectin structure. In the absence of starch-branching enzyme $\mathrm{IIb}$, the further absence of starch-branching enzyme Ia leads to increased branching. Plant Physiol. 2004, 136, 3515-3523. [CrossRef] [PubMed]

288. Tetlow, I.J.; Wait, R.; Lu, Z.; Akkasaeng, R.; Bowsher, C.G.; Esposito, S.; Kosar-Hashemi, B.; Morell, M.K.; Emes, M.J. Protein Phosphorylation in Amyloplasts Regulates Starch Branching Enzyme Activity and Protein-Protein Interactions. Plant Cell 2004, 16, 694-708. [CrossRef] [PubMed]

289. Liu, F.; Ahmed, Z.; Lee, E.A.; Donner, E.; Liu, Q.; Ahmed, R.; Morell, M.K.; Emes, M.J.; Tetlow, I.J. Allelic variants of the amylose extender mutation of maize demonstrate phenotypic variation in starch structure resulting from modified protein-protein interactions. J. Exp. Bot. 2012, 63, 1167-1183. [CrossRef] [PubMed] 
290. Ahmed, Z.; Tetlow, I.J.; Ahmed, R.; Morell, M.K.; Emes, M.J. Protein-protein interactions among enzymes of starch biosynthesis in high-amylose barley genotypes reveal differential roles of heteromeric enzyme complexes in the synthesis of A and B granules. Plant Sci. 2015, 233, 95-106. [CrossRef] [PubMed]

291. Crofts, N.; Abe, N.; Oitome, N.F.; Matsushima, R.; Hayashi, M.; Tetlow, I.J.; Emes, M.J.; Nakamura, Y.; Fujita, N. Amylopectin biosynthetic enzymes from developing rice seed form enzymatically active protein complexes. J. Exp. Bot. 2015, 66, 4469-4482. [CrossRef] [PubMed]

292. Xia, H.; Yandeau-Nelson, M.; Thompson, D.B.; Guiltinan, M.J. Deficiency of maize starch-branching enzyme i results in altered starch fine structure, decreased digestibility and reduced coleoptile growth during germination. BMC Plant Biol. 2011, 11, 95. [CrossRef] [PubMed]

293. Fisher, D.K.; Gao, M.; Kim, K.N.; Boyer, C.D.; Guiltinan, M.J. Allelic Analysis of the Maize amylose-extender Locus Suggests That Independent Genes Encode Starch-Branching Enzymes IIa and IIb. Plant Physiol. 1996, 110, 611-619. [CrossRef] [PubMed]

294. Gao, M.; Fisher, D.K.; Kim, K.N.; Shannon, J.C.; Guiltinan, M.J. Independent genetic control of maize starch-branching enzymes IIa and IIb. Isolation and characterization of a Sbe2a cDNA. Plant Physiol. 1997, 114, 69-78. [CrossRef] [PubMed]

295. Tyler, L.; Bragg, J.N.; Wu, J.; Yang, X.; Tuskan, G.A.; Vogel, J.P. Annotation and comparative analysis of the glycoside hydrolase genes in Brachypodium distachyon. BMC Genom. 2010, 11, 600. [CrossRef] [PubMed]

296. Mizuno, K.; Kawasaki, T.; Shimada, H.; Satoh, H.; Kobayashi, E.; Okumura, S.; Arai, Y.; Baba, T. Alteration of the structural properties of starch components by the lack of an isoform of starch branching enzyme in rice seeds. J. Biol. Chem. 1993, 268, 19084-19091. [PubMed]

297. Regina, A.; Bird, A.; Topping, D.; Bowden, S.; Freeman, J.; Barsby, T.; Kosar-Hashemi, B.; Li, Z.; Rahman, S.; Morell, M. High-amylose wheat generated by RNA interference improves indices of large-bowel health in rats. Proc. Natl. Acad. Sci. USA 2006, 103, 3546-3551. [CrossRef] [PubMed]

298. Regina, A.; Kosar-Hashemi, B.; Li, Z.; Pedler, A.; Mukai, Y.; Yamamoto, M.; Gale, K.; Sharp, P.J.; Morell, M.K.; Rahman, S. Starch branching enzyme IIb in wheat is expressed at low levels in the endosperm compared to other cereals and encoded at a non-syntenic locus. Planta 2005, 222, 899-909. [CrossRef] [PubMed]

299. Yu, Y.; Mu, H.H.; Wasserman, B.P.; Carman, G.M. Identification of the maize amyloplast stromal 112-kD protein as a plastidic starch phosphorylase. Plant Physiol. 2001, 125, 351-359. [CrossRef] [PubMed]

300. Sun, C.; Sathish, P.; Ahlandsberg, S.; Jansson, C. The two genes encoding starch-branching enzymes IIa and $\mathrm{IIb}$ are differentially expressed in barley. Plant Physiol. 1998, 118, 37-49. [CrossRef] [PubMed]

301. Regina, A.; Kosar-Hashemi, B.; Ling, S.; Li, Z.; Rahman, S.; Morell, M. Control of starch branching in barley defined through differential RNAi suppression of starch branching enzyme IIa and Ilb. J. Exp. Bot. 2010, 61, 1469-1482. [CrossRef] [PubMed]

302. Cuesta-Seijo, J.A.; Ruzanski, C.; Krucewicz, K.; Meier, S.; Hägglund, P.; Svensson, B.; Palcic, M.M. Functional and structural characterization of plastidic starch phosphorylase during barley endosperm development. PLoS ONE 2017, 12, e0175488. [CrossRef] [PubMed]

303. Banks, W.; Greenwood, C.T.; Muir, D. Studies on starches of high amylose-content. Die Stärke 1974, 9, $289-328$. [CrossRef]

304. Blauth, S.L. Identification of Mutator Insertional Mutants of Starch-Branching Enzyme 2a in Corn. Plant Physiol. 2001, 125, 1396-1405. [CrossRef] [PubMed]

305. Butardo, V.M.; Fitzgerald, M.A.; Bird, A.R.; Gidley, M.J.; Flanagan, B.M.; Larroque, O.; Resurreccion, A.P.; Laidlaw, H.K.C.; Jobling, S.A.; Morell, M.K.; et al. Impact of down-regulation of starch branching enzyme Ilb in rice by artificial microRNA-and hairpin RNA-mediated RNA silencing. J. Exp. Bot. 2011, 62, 4927-4941. [CrossRef] [PubMed]

306. Klucinec, J.D.; Thompson, D.B. Structure of amylopectins from ae -containing maize starches. Cereal Chem. 2002, 79, 19-23. [CrossRef]

307. Wellner, N.; Georget, D.M.R.; Parker, M.L.; Morris, V.J. In situ Raman microscopy of starch granule structures in wild type and ae mutant maize kernels. Starch/Staerke 2011, 63, 128-138. [CrossRef]

308. Shaik, S.S.; Obata, T.; Hebelstrup, K.H.; Schwahn, K.; Fernie, A.R.; Mateiu, R.V.; Blennow, A. Starch granule re-structuring by starch branching enzyme and glucan water dikinase modulation affects caryopsis physiology and metabolism. PLoS ONE 2016, 11, e0149613. [CrossRef] [PubMed] 
309. Slade, A.J.; McGuire, C.; Loeffler, D.; Mullenberg, J.; Skinner, W.; Fazio, G.; Holm, A.; Brandt, K.M.; Steine, M.N.; Goodstal, J.F.; et al. Development of high amylose wheat through TILLING. BMC Plant Biol. 2012, 12, 69. [CrossRef] [PubMed]

310. Sparla, F.; Falini, G.; Botticella, E.; Pirone, C.; Talamè, V.; Bovina, R.; Salvi, S.; Tuberosa, R.; Sestili, F.; Trost, P. New starch phenotypes produced by TILLING in barley. PLoS ONE 2014, 9, e0107779. [CrossRef] [PubMed]

311. Hazard, B.; Zhang, X.; Colasuonno, P.; Uauy, C.; Beckles, D.M.; Dubcovsky, J. Induced Mutations in the Starch Branching Enzyme II (SBEII) Genes Increase Amylose and Resistant Starch Content in Durum Wheat. Crop Sci. 2012, 52, 1754-1766. [CrossRef] [PubMed]

312. Denyer, K.; Hylton, C.M.; Jenner, C.F.; Smith, A.M. Identification of multiple isoforms of soluble and granule-bound starch synthase in developing wheat endosperm. Planta Int. J. Plant Biol. 1995, 196, 256-265. [CrossRef]

313. Rahman, S.; Kosar-Hashemi, B.; Samuel, M.; Hill, A.; Abbott, D.; Skerritt, J.; Preiss, J.; Appels, R.; Morell, M. The Major Proteins of Wheat Endosperm Starch Granules. Aust. J. Plant Physiol. 1995, 22, 793-803. [CrossRef]

314. Borén, M.; Larsson, H.; Falk, A.; Jansson, C. The barley starch granule proteome-Internalized granule polypeptides of the mature endosperm. Plant Sci. 2004, 166, 617-626. [CrossRef]

315. Liu, F.; Makhmoudova, A.; Lee, E.A.; Wait, R.; Emes, M.J.; Tetlow, I.J. The amylose extender mutant of maize conditions novel protein-protein interactions between starch biosynthetic enzymes in amyloplasts. J. Exp. Bot. 2009, 60, 4423-4440. [CrossRef] [PubMed]

316. Makhmoudova, A.; Williams, D.; Brewer, D.; Massey, S.; Patterson, J.; Silva, A.; Vassall, K.A.; Liu, F.; Subedi, S.; Harauz, G.; et al. Identification of multiple phosphorylation sites on maize endosperm starch branching enzyme Ilb, a key enzyme in amylopectin biosynthesis. J. Biol. Chem. 2014, 289, 9233-9246. [CrossRef] [PubMed]

317. Crofts, N.; Nakamura, Y.; Fujita, N. Critical and speculative review of the roles of multi-protein complexes in starch biosynthesis in cereals. Plant Sci. 2017, 262, 1-8. [CrossRef] [PubMed]

318. Tetlow, I.J.; Beisel, K.G.; Cameron, S.; Makhmoudova, A.; Liu, F.; Bresolin, N.S.; Wait, R.; Morell, M.K.; Emes, M.J. Analysis of Protein Complexes in Wheat Amyloplasts Reveals Functional Interactions among Starch Biosynthetic Enzymes. Plant Physiol. 2008, 146, 1878-1891. [CrossRef] [PubMed]

319. Tanaka, N.; Fujita, N.; Nishi, A.; Satoh, H.; Hosaka, Y.; Ugaki, M.; Kawasaki, S.; Nakamura, Y. The structure of starch can be manipulated by changing the expression levels of starch branching enzyme IIb in rice endosperm. Plant Biotechnol. J. 2004, 2, 507-516. [CrossRef] [PubMed]

320. Lin, Q.; Facon, M.; Putaux, J.L.; Dinges, J.R.; Wattebled, F.; D’Hulst, C.; Hennen-Bierwagen, T.A.; Myers, A.M. Function of isoamylase-type starch debranching enzymes ISA1 and ISA2 in the Zea mays leaf. New Phytol. 2013, 200, 1009-1021. [CrossRef] [PubMed]

321. Dinges, J.R.; Colleoni, C.; James, M.G.; Myers, A.M. Mutational analysis of the pullulanase-type debranching enzyme of maize indicates multiple functions in starch metabolism. Plant Cell 2003, 15, 666-680. [CrossRef] [PubMed]

322. Wattebled, F.; Dong, Y.; Dumez, S.; Delvallé, D.; Planchot, V.; Berbezy, P.; Vyas, D.; Colonna, P.; Chatterjee, M.; Ball, S.; et al. Mutants of Arabidopsis lacking a chloroplastic isoamylase accumulate phytoglycogen and an abnormal form of amylopectin. Plant Physiol. 2005, 138, 184-195. [CrossRef] [PubMed]

323. Delatte, T.; Umhang, M.; Trevisan, M.; Eicke, S.; Thorneycroft, D.; Smith, S.M.; Zeeman, S.C. Evidence for distinct mechanisms of starch granule breakdown in plants. J. Biol. Chem. 2006, 281, 12050-12059. [CrossRef] [PubMed]

324. Yun, M.S.; Umemoto, T.; Kawagoe, Y. Rice debranching enzyme isoamylase3 facilitates starch metabolism and affects plastid morphogenesis. Plant Cell Physiol. 2011, 52, 1068-1082. [CrossRef] [PubMed]

325. Morris, D.; Morris, C. Glycogen in the seed of Zea mays. J. Biol. Chem. 1939, 130, 535-544.

326. James, M.G.; Robertson, D.S.; Myers, A.M.; James, M.G.; Robertson, D.S.; Myers, A.N. Characterization of the Maize Gene sugary1, a Determinant Characterization in Kernels of Starch Composition in kernels. Plant Cell 2015, 7, 417-429. [CrossRef] [PubMed]

327. Burton, R.A.; Jenner, H.; Carrangis, L.; Fahy, B.; Fincher, G.B.; Hylton, C.; Laurie, D.A.; Parker, M.; Waite, D.; Van Wegen, S.; et al. Starch granule initiation and growth are altered in barley mutants that lack isoamylase activity. Plant J. 2002, 31, 97-112. [CrossRef] [PubMed]

328. Kubo, A.; Rahman, S.; Utsumi, Y.; Li, Z.; Mukai, Y.; Yamamoto, M.; Ugaki, M.; Harada, K.; Satoh, H.; Konik-Rose, C.; et al. Complementation of sugary-1 phenotype in rice endosperm with the wheat isoamylase1 
gene supports a direct role for isoamylase1 in amylopectin biosynthesis. Plant Physiol. 2005, 137, 43-56. [CrossRef] [PubMed]

329. Dinges, J.R.; Colleoni, C.; Myers, A.M.; James, M.G. Molecular structure of three mutations at the maize sugary1 locus and their allele-specific phenotypic effects. Plant Physiol. 2001, 125, 1406-1418. [CrossRef] [PubMed]

330. Rahman, S.; Nakamura, Y.; Li, Z.; Clarke, B.; Fujita, N.; Mukai, M.; Yamamoto, M.; Regina, A.; Tan, Z.; Kawasaki, S.; et al. The sugary-type isoamylase gene from rice and Aegilops tauschii: Characterization and comparison with maize and Arabidopsis. Genome 2003, 46, 496-506. [CrossRef] [PubMed]

331. Nielsen, T.H.; Baunsgaard, L.; Blennow, A. Intermediary glucan structures formed during starch granule biosynthesis are enriched in short side chains, a dynamic pulse labeling approach. J. Biol. Chem. 2002, 277, 20249-20255. [CrossRef] [PubMed]

332. Gidley, M.; Bulpin, P. Crystallisation of malto-oligosaccharides as models of the crystalline forms of starch: Minimum chain-length requirement for the formation of double helices. Carbohydr. Res. 1987, 161, 291-300. [CrossRef]

333. Ball, S.; Guan, H.; James, M.; Myers, A.; Keeling, P.; Mouille, G.; Colonna, P.; Preiss, J. From Glycogen to Amylopectin: A Model for the Biogenesis of the Plant Starch Granule. Cell 1996, 86, 349-352. [CrossRef]

334. Mouille, G. Preamylopectin Processing: A Mandatory Step for Starch Biosynthesis in Plants. Plant Cell Online 1996, 8, 1353-1366. [CrossRef] [PubMed]

335. Sim, L.; Beeren, S.R.; Findinier, J.; Dauville, D.; Ball, S.G.; Henriksen, A.; Palcic, M.M. Crystal structure of the Chlamydomonas starch debranching enzyme isoamylase ISA1 reveals insights into the mechanism of branch trimming and complex assembly. J. Biol. Chem. 2014, 289, 22991-23003. [CrossRef] [PubMed]

336. Zeeman, S.C.; Umemoto, T.; Lue, W.L.; Au-Yeung, P.; Martin, C.; Smith, A.M.; Chen, J. A mutant of Arabidopsis lacking a chloroplastic isoamylase accumulates both starch and phytoglycogen. Plant Cell 1998, 10, 1699-1712. [CrossRef] [PubMed]

337. Fujita, N.; Hanashiro, I.; Suzuki, S.; Higuchi, T.; Toyosawa, Y.; Utsumi, Y.; Itoh, R.; Aihara, S.; Nakamura, Y. Elongated phytoglycogen chain length in transgenic rice endosperm expressing active starch synthase IIa affects the altered solubility and crystallinity of the storage $\alpha$-glucan. J. Exp. Bot. 2012, 63, 5859-5872. [CrossRef] [PubMed]

338. Streb, S.; Delatte, T.; Umhang, M.; Eicke, S.; Schorderet, M.; Reinhardt, D.; Zeeman, S.C. Starch Granule Biosynthesis in Arabidopsis Is Abolished by Removal of All Debranching Enzymes but Restored by the Subsequent Removal of an Endoamylase. Plant Cell Online 2008, 20, 3448-3466. [CrossRef] [PubMed]

339. Kubo, A.; Fujita, N.; Harada, K.; Matsuda, T.; Satoh, H.; Nakamura, Y. The starch-debranching enzymes isoamylase and pullulanase are both involved in amylopectin biosynthesis in rice endosperm. Plant Physiol. 1999, 121, 399-410. [CrossRef] [PubMed]

340. Fujita, N.; Toyosawa, Y.; Utsumi, Y.; Higuchi, T.; Hanashiro, I.; Ikegami, A.; Akuzawa, S.; Yoshida, M.; Mori, A.; Inomata, K.; et al. Characterization of pullulanase (PUL)-deficient mutants of rice (Oryza sativa L.) and the function of PUL on starch biosynthesis in the developing rice endosperm. J. Exp. Bot. 2009, 60, 1009-1023. [CrossRef] [PubMed]

341. Delatte, T.; Trevisan, M.; Parker, M.L.; Zeeman, S.C. Arabidopsis mutants Atisa1 and Atisa2 have identical phenotypes and lack the same multimeric isoamylase, which influences the branch point distribution of amylopectin during starch synthesis. Plant J. 2005, 41, 815-830. [CrossRef] [PubMed]

342. Kawagoe, Y.; Kubo, A.; Satoh, H.; Takaiwa, F.; Nakamura, Y. Roles of isoamylase and ADP-glucose pyrophosphorylase in starch granule synthesis in rice endosperm. Plant J. 2005, 42, 164-174. [CrossRef] [PubMed]

343. Sundberg, M.; Pfister, B.; Fulton, D.; Bischof, S.; Delatte, T.; Eicke, S.; Stettler, M.; Smith, S.M.; Streb, S.; Zeeman, S.C. The Heteromultimeric Debranching Enzyme Involved in Starch Synthesis in Arabidopsis Requires Both Isoamylase1 and Isoamylase2 Subunits for Complex Stability and Activity. PLoS ONE 2013, 8. [CrossRef] [PubMed]

344. Facon, M.; Lin, Q.; Azzaz, A.M.; Hennen-Bierwagen, T.A.; Myers, A.M.; Putaux, J.-L.; Roussel, X.; D’Hulst, C.; Wattebled, F. Distinct Functional Properties of Isoamylase-Type Starch Debranching Enzymes in Monocot and Dicot Leaves. Plant Physiol. 2013, 163, 1363-1375. [CrossRef] [PubMed] 
345. Hussain, H.; Mant, A.; Seale, R.; Zeeman, S.; Hinchliffe, E.; Edwards, A.; Hylton, C.; Bornemann, S.; Smith, A.M.; Martin, C.; et al. Three isoforms of isoamylase contribute different catalytic properties for the debranching of potato glucans. Plant Cell 2003, 15, 133-149. [CrossRef] [PubMed]

346. Kubo, A.; Colleoni, C.; Dinges, J.R.; Lin, Q.; Lappe, R.R.; Rivenbark, J.G.; Meyer, A.J.; Ball, S.G.; James, M.G.; Hennen-Bierwagen, T.A.; et al. Functions of Heteromeric and Homomeric Isoamylase-Type Starch-Debranching Enzymes in Developing Maize Endosperm. Plant Physiol. 2010, 153, 956-969. [CrossRef] [PubMed]

347. Utsumi, Y.; Utsumi, C.; Sawada, T.; Fujita, N.; Nakamura, Y. Functional Diversity of Isoamylase Oligomers: The ISA1 Homo-Oligomer Is Essential for Amylopectin Biosynthesis in Rice Endosperm. Plant Physiol. 2011, 156, 61-77. [CrossRef] [PubMed]

348. Utsumi, Y.; Nakamura, Y. Structural and enzymatic characterization of the isoamylase1 homo-oligomer and the isoamylase1-isoamylase2 hetero-oligomer from rice endosperm. Planta 2006, 225, 75-87. [CrossRef] [PubMed]

349. Hanes, C. The reversible formation of starch from glucose-1-phosphate catalysed by potato phosphorylase. Proc. R. Soc. Lond. B Biol. Sci. 1940, 129, 174-208. [CrossRef]

350. Dauvillée, D.; Chochois, V.; Steup, M.; Haebel, S.; Eckermann, N.; Ritte, G.; Ral, J.P.; Colleoni, C.; Hicks, G.; Wattebled, F.; et al. Plastidial phosphorylase is required for normal starch synthesis in Chlamydomonas reinhardtii. Plant J. 2006, 48, 274-285. [CrossRef] [PubMed]

351. Burr, B.; Nelson, O.E.; Phosphorylase, M. Maize $\alpha$-Glucan Phosphorylase. Eur. J. Biochem. 1975, 546, $539-546$. [CrossRef]

352. Yang, Y.; Steup, M. Polysaccharide Fraction from Higher Plants which Strongly Interacts with the Cytosolic Phosphorylase Isozyme: I. Isolation and Characterization. Plant Physiol. 1990, 94, 960-969. [CrossRef] [PubMed]

353. Tsai, C.Y.; Salamini, F.; Nelson, O.E. Enzymes of Carbohydrate Metabolism in the Developing Endosperm of Maize. Plant Physiol. 1970, 46, 299-306. [CrossRef] [PubMed]

354. Higgins, J.E.; Kosar-Hashemi, B.; Li, Z.; Howitt, C.A.; Larroque, O.; Flanagan, B.; Morell, M.K.; Rahman, S. Characterization of starch phosphorylases in barley grains. J. Sci. Food Agric. 2013, 93, 2137-2145. [CrossRef] [PubMed]

355. Satoh, H.; Shibahara, K.; Tokunaga, T.; Nishi, A.; Tasaki, M.; Hwang, S.-K.; Okita, T.W.; Kaneko, N.; Fujita, N.; Yoshida, M.; et al. Mutation of the Plastidial $\alpha$-Glucan Phosphorylase Gene in Rice Affects the Synthesis and Structure of Starch in the Endosperm. Plant Cell Online 2008, 20, 1833-1849. [CrossRef] [PubMed]

356. Sonnewald, U.; Basner, A.; Greve, B.; Steup, M. A second L-type isozyme of potato glucan phosphorylase: Cloning, antisense inhibition and expression analysis. Plant Mol. Biol. 1995, 27, 567-576. [CrossRef] [PubMed]

357. Zeeman, S.C.; Thorneycroft, D.; Schupp, N.; Chapple, A.; Weck, M.; Dunstan, H.; Haldimann, P.; Bechtold, N.; Smith, A.M.; Smith, S.M. Plastidial alpha-glucan phosphorylase is not required for starch degradation in Arabidopsis leaves but has a role in the tolerance of abiotic stress. Plant Physiol. 2004, 135, 849-858. [CrossRef] [PubMed]

358. Tetlow, I.J.; Blissett, K.J.; Emes, M.J. Metabolite pools during starch synthesis and carbohydrate oxidation in amyloplasts isolated from wheat endosperm. Planta 1998, 204, 100-108. [CrossRef]

359. Hwang, S.K.; Nishi, A.; Satoh, H.; Okita, T.W. Rice endosperm-specific plastidial $\alpha$-glucan phosphorylase is important for synthesis of short-chain malto-oligosaccharides. Arch. Biochem. Biophys. 2010, 495, 82-92. [CrossRef] [PubMed]

360. Radchuk, V.V.; Borisjuk, L.; Sreenivasulu, N.; Merx, K.; Mock, H.-P.; Rolletschek, H.; Wobus, U.; Weschke, W. Spatiotemporal Profiling of Starch Biosynthesis and Degradation in the Developing Barley Grain. Plant Physiol. 2009, 150, 190-204. [CrossRef] [PubMed]

361. Rodriguez-López, M.; Baroja-Fernández, E.; Zandueta-Criado, A.; Pozueta-Romero, J. Adenosine diphosphate glucose pyrophosphatase: A plastidial phosphodiesterase that prevents starch biosynthesis. Proc. Natl. Acad. Sci. USA 2000, 97, 8705-8710. [CrossRef] [PubMed]

362. Nakamura, Y.; Ono, M.; Utsumi, C.; Steup, M. Functional interaction between plastidial starch phosphorylase and starch branching enzymes from rice during the synthesis of branched maltodextrins. Plant Cell Physiol. 2012, 53, 869-878. [CrossRef] [PubMed] 
363. Subasinghe, R.M.; Liu, F.; Polack, U.C.; Lee, E.A.; Emes, M.J.; Tetlow, I.J. Multimeric states of starch phosphorylase determine protein-protein interactions with starch biosynthetic enzymes in amyloplasts. Plant Physiol. Biochem. 2014, 83, 168-179. [CrossRef] [PubMed]

364. Nakano, K.; Fukui, T. The complete amino acid sequence of potato alpha-glucan phosphorylase. J. Biol. Chem. 1986, 261, 8230-8236. [PubMed]

365. Albrecht, T.; Greve, B.; Pusch, K.; Kossmann, J.; Buchner, P.; Wobus, U.; Steup, M. Homodimers and heterodimers of Pho1-type phosphorylase isoforms in Solanum tuberosum L. as revealed by sequence-specific antibodies. Eur. J. Biochem. 1998, 251, 343-352. [CrossRef] [PubMed]

366. Buchbinder, J.L.; Rath, V.L.; Fletterick, R.J. Structural relationships among regulated and unregulated phosphorylases. Annu. Rev. Biophys. Biomol. Struct. 2001, 30, 191-209. [CrossRef] [PubMed]

367. Takaha, T.; Yanase, M.; Okada, S.; Smith, S.M. Disproportionating enzyme (4- $\alpha$-glucanotransferase; EC 2.4.1.25) of potato. Purification, molecular cloning, and potential role in starch metabolism. J. Biol. Chem. 1993, 268, 1391-1396. [PubMed]

368. Colleoni, C.; Dauville, D.; Mouille, G.; Morell, M.; Samuel, M.; Slomiany, M.C.; Li nard, L.; Wattebled, F.; d'Hulst, C.; Ball, S. Biochemical characterization of the Chlamydomonas reinhardtii alpha-1,4 glucanotransferase supports a direct function in amylopectin biosynthesis. Plant Physiol. 1999, 120, 1005-1014. [CrossRef] [PubMed]

369. Colleoni, C.; Dauville, D.; Mouille, G.; Bulon, A.; Gallant, D.; Bouchet, B.; Morell, M.; Samuel, M.; Delrue, B.; d'Hulst, C.; et al. Genetic and biochemical evidence for the involvement of alpha-1,4 glucanotransferases in amylopectin synthesis. Plant Physiol. 1999, 120, 993-1004. [CrossRef] [PubMed]

370. Hwang, S.K.; Koper, K.; Satoh, H.; Okita, T.W. Rice endosperm starch phosphorylase (Pho1) assembles with disproportionating enzyme (Dpe1) to form a protein complex that enhances synthesis of malto-oligosaccharides. J. Biol. Chem. 2016, 291, 19994-20007. [CrossRef] [PubMed]

371. Lin, T.P.; Preiss, J. Characterization of d-Enzyme (4-alpha-Glucanotransferase) in Arabidopsis Leaf. Plant Physiol. 1988, 86, 260-265. [CrossRef] [PubMed]

372. Weber, A.P.M.; Schwacke, R.; Flügge, U.-I. Solute Transporters of the Plastid Envelope Membrane. Annu. Rev. Plant Biol. 2005, 56, 133-164. [CrossRef] [PubMed]

373. Niittyla, T. A Previously Unknown Maltose Transporter Essential for Starch Degradation in Leaves. Science 2004, 303, 87-89. [CrossRef] [PubMed]

374. Critchley, J.H.; Zeeman, S.C.; Takaha, T.; Smith, A.M.; Smith, S.M. A critical role for disproportionating enzyme in starch breakdown is revealed by a knock-out mutation in Arabidopsis. Plant J. 2001, 26, 89-100. [CrossRef] [PubMed]

375. Bresolin, N.S.; Li, Z.; Kosar-Hashemi, B.; Tetlow, I.J.; Chatterjee, M.; Rahman, S.; Morell, M.K.; Howitt, C.A. Characterisation of disproportionating enzyme from wheat endosperm. Planta 2006, 224, 20-31. [CrossRef] [PubMed]

376. Dong, X.; Zhang, D.; Liu, J.; Liu, Q.Q.; Liu, H.; Tian, L.; Jiang, L.; Qule, Q. Plastidial Disproportionating Enzyme Participates in Starch Synthesis in Rice Endosperm by Transferring Maltooligosyl Groups from Amylose and Amylopectin to Amylopectin. Plant Physiol. 2015, 169, 2496-2512. [CrossRef] [PubMed]

377. Hizukuri, S.; Tabata, S.; Kagoshima; Nikuni, Z. Studies on Starch Phosphate Part 1. Estimation of glucose-6-phosphate residues in starch and the presence of other bound phosphate(s). Starch Stärke 1970, 22, 338-343. [CrossRef]

378. Ritte, G.; Lloyd, J.R.; Eckermann, N.; Rottmann, A.; Kossmann, J.; Steup, M. The starch-related R1 protein is an alpha-glucan, water dikinase. Proc. Natl. Acad. Sci. USA 2002, 99, 7166-7171. [CrossRef] [PubMed]

379. Ritte, G.; Heydenreich, M.; Mahlow, S.; Haebel, S.; Kötting, O.; Steup, M. Phosphorylation of C6- and C3-positions of glucosyl residues in starch is catalysed by distinct dikinases. FEBS Lett. 2006, 580, 4872-4876. [CrossRef] [PubMed]

380. Baunsgaard, L.; Lütken, H.; Mikkelsen, R.; Glaring, M.A.; Pham, T.T.; Blennow, A. A novel isoform of glucan, water dikinase phosphorylates pre-phosphorylated $\alpha$-glucans and is involved in starch degradation in Arabidopsis. Plant J. 2005, 41, 595-605. [CrossRef] [PubMed]

381. Blennow, A.; Engelsen, S.B.; Munck, L.; Møller, B.L. Starch molecular structure and phosphorylation investigated by a combined chromatographic and chemometric approach. Carbohydr. Polym. 2000, 41, 163-174. [CrossRef] 
382. Kotting, O.; Santelia, D.; Edner, C.; Eicke, S.; Marthaler, T.; Gentry, M.S.; Comparot-Moss, S.; Chen, J.; Smith, A.M.; Steup, M.; et al. STARCH-EXCESS4 Is a Laforin-Like Phosphoglucan Phosphatase Required for Starch Degradation in Arabidopsis thaliana. Plant Cell Online 2009, 21, 334-346. [CrossRef] [PubMed]

383. Ral, J.P.; Bowerman, A.F.; Li, Z.; Sirault, X.; Furbank, R.; Pritchard, J.R.; Bloemsma, M.; Cavanagh, C.R.; Howitt, C.A.; Morell, M.K. Down-regulation of Glucan, Water-Dikinase activity in wheat endosperm increases vegetative biomass and yield. Plant Biotechnol. J. 2012, 10, 871-882. [CrossRef] [PubMed]

384. Chen, Y.; Sun, X.; Zhou, X.; Hebelstrup, K.H.; Blennow, A.; Bao, J. Highly phosphorylated functionalized rice starch produced by transgenic rice expressing the potato GWD1 gene. Sci. Rep. 2017, 7, 3339. [CrossRef] [PubMed]

385. Ziegler, G.R.; Creek, J.A.; Runt, J. Spherulitic crystallization in starch as a model for starch granule initiation. Biomacromolecules 2005, 6, 1547-1554. [CrossRef] [PubMed]

386. Puteaux, J.; Potocki-Veronese, G.; Remaud-Simeon, M.; Buléon, A. Alpha-D-glucan-based dendritic nanoparticles prepared by in vitro enzymatic chain extension of glycogen. Biomacromolecules 2006, 7, 1720-1728. [CrossRef] [PubMed]

387. Fannon, J.E.; Hauber, R.J.; Bemiller, J.N. Surface pores of starch granules. Cereal Chem. 1992, 69, $284-288$.

388. Fannon, J.E.; Gray, J.A.; Gunawan, N.; Huber, K.C.; BeMiller, J.N. Heterogeneity of starch granules and the effect of granule channelization on starch modification. Cellulose 2004, 11, 247-254. [CrossRef]

389. Glaring, M.A.; Koch, C.B.; Blennow, A. Genotype-specific spatial distribution of starch molecules in the starch granule: A combined CLSM and SEM approach. Biomacromolecules 2006, 7, 2310-2320. [CrossRef] [PubMed]

390. Huber, K.C.; BeMiller, J.N. Visualization of channels and cavities of corn and sorghum starch granules. Cereal Chem. 1997, 74, 537-541. [CrossRef]

391. Benmoussa, M.; Hamaker, B.R.; Huang, C.P.; Sherman, D.M.; Weil, C.F.; BeMiller, J.N. Elucidation of maize endosperm starch granule channel proteins and evidence for plastoskeletal structures in maize endosperm amyloplasts. J. Cereal Sci. 2010, 52, 22-29. [CrossRef]

392. Jane, J.-L.; Kasemsuwan, T.; Leas, S.; Zobel, H.; Robyt, J.F. Anthology of Starch Granule Morphology by Scanning Electron Microscopy. Starch Stärke 1994, 46, 121-129. [CrossRef]

393. Ellis, R.P.; Cochrane, M.P.; Dale, M.F.B.; Dupus, C.M.; Lynn, A.; Morrison, I.M.; Prentice, R.D.M.; Swanston, J.S.; Tiller, S.A. Starch Production and Industrial Use. J. Sci. Food Agric. 1998, 77, $289-311$. [CrossRef]

394. Lindeboom, N.; Chang, P.R.; Tyler, R.T. Analytical, Biochemical and Physicochemical Aspects of Starch Granule Size, with Emphasis on Small Granule Starches: A Review. Starch Stärke 2004, 56, 89-99. [CrossRef]

395. Jobling, S. Improving starch for food and industrial applications. Curr. Opin. Plant Biol. 2004, 7, $210-218$. [CrossRef] [PubMed]

396. Ai, Y.; Gong, L.; Reed, M.; Huang, J.; Zhang, Y.; Jane, J.L. Characterization of starch from bamboo seeds. Starch/Staerke 2016, 68, 131-139. [CrossRef]

397. Buléon, A.; Colonna, P.; Planchot, V.; Ball, S. Starch granules: Structure and biosynthesis. Int. J. Biol. Macromol. 1998, 23, 85-112. [CrossRef]

398. Chen, G.; Zhu, J.; Zhou, J.; Subburaj, S.; Zhang, M.; Han, C.; Hao, P.; Li, X.; Yan, Y. Dynamic development of starch granules and the regulation of starch biosynthesis in Brachypodium distachyon: Comparison with common wheat and Aegilops peregrina. BMC Plant Biol. 2014, 14, 198. [CrossRef] [PubMed]

399. Meredith, P. Large and Small Starch Granules in Wheat-Are They Really Different? Starch Stärke 1981, 33, 40-44. [CrossRef]

400. May, L.; Buttrose, M. Physiology of cereal grain. II. Starch granule formation in the developing barley kernel. Aust. J. Biol. Sci. 1959, 12, 146-159. [CrossRef]

401. Bechtel, D.B.; Zayas, I.; Kaleikau, L.; Pomeranz, Y. Size-distribution of wheat starch granules during endosperm development. Cereal Chem. 1990, 67, 59-63.

402. Shapter, F.M.; Henry, R.J.; Lee, L.S. Endosperm and starch granule morphology in wild cereal relatives. Plant Genet. Resour. 2008, 6, 85-97. [CrossRef]

403. Shapter, F.M.; Eggler, P.; Lee, L.S.; Henry, R.J. Variation in Granule Bound Starch Synthase I (GBSSI) loci amongst Australian wild cereal relatives (Poaceae). J. Cereal Sci. 2009, 49, 4-11. [CrossRef]

404. Tateoka, T. Starch grains of endosperm in grass systematics. Bot. Mag. Tokyo 1962, 75, 377-383. [CrossRef] 
405. Draper, J.; Mur, L.A.J.; Jenkins, G.; Ghosh-Biswas, G.C.; Bablak, P.; Hasterok, R.; Routledge, A.P.M. Brachypodium distachyon. A New Model System for Functional Genomics in Grasses1. Plant Physiol. 2001, 127, 1539-1555. [CrossRef] [PubMed]

406. Tanackovic, V.; Svensson, J.T.; Jensen, S.L.; Buléon, A.; Blennow, A. The deposition and characterization of starch in Brachypodium distachyon. J. Exp. Bot. 2014, 65, 5179-5192. [CrossRef] [PubMed]

407. Evers, A.D. The Size Distriubution Among Starch Granules in Wheat Endosperm. Starch Stärke 1973, 25, 304-308. [CrossRef]

408. Parker, M.L. The relationship between A-type and B-type starch granules in the developing endosperm of wheat. J. Cereal Sci. 1985, 3, 271-278. [CrossRef]

409. Dengate, H.; Meredith, P. Variation in size distribution of starch granules from wheat grain. J. Cereal Sci. 1984, 2, 83-90. [CrossRef]

410. Wilson, J.; Bechtel, D.; Todd, T.; Seib, P. Measurement of wheat starch granule size distribution using image analysis and laser diffraction technology. Cereal Chem. 2006, 83, 259-268. [CrossRef]

411. Stoddard, F.L.; Sarker, R. Characterization of starch in Aegilops species. Cereal Chem. 2000, 77, 445-447. [CrossRef]

412. Wei, C.; Zhang, J.; Chen, Y.; Zhou, W.; Xu, B.; Wang, Y.; Chen, J. Physicochemical properties and development of wheat large and small starch granules during endosperm development. Acta Physiol. Plant. 2010, 32, 905-916. [CrossRef]

413. Salman, H.; Blazek, J.; Lopez-Rubio, A.; Gilbert, E.P.; Hanley, T.; Copeland, L. Structure-function relationships in A and B granules from wheat starches of similar amylose content. Carbohydr. Polym. 2009, 75, 420-427. [CrossRef]

414. Ahmed, Z.; Tetlow, I.J.; Falk, D.E.; Liu, Q.; Emes, M.J. Resistant starch content is related to granule size in barley. Cereal Chem. 2016, 93, 618-630. [CrossRef]

415. Langeveld, S.M.; van Wijk, R.; Stuurman, N.; Kijne, J.W.; de Pater, S. B-type granule containing protrusions and interconnections between amyloplasts in developing wheat endosperm revealed by transmission electron microscopy and GFP expression. J. Exp. Bot. 2000, 51, 1357-1361. [CrossRef] [PubMed]

416. Bechtel, D.B.; Wilson, J.D. Amyloplast formation and starch granule development in hard red winter wheat. Cereal Chem. 2003, 80, 175-183. [CrossRef]

417. Stahl, Y.; Coates, S.; Bryce, J.H.; Morris, P.C. Antisense downregulation of the barley limit dextrinase inhibitor modulates starch granule size distribution, starch composition and amylopectin structure. Plant J. 2004, 39, 599-611. [CrossRef] [PubMed]

418. Howard, T.; Rejab, N.A.; Griffiths, S.; Leigh, F.; Leverington-Waite, M.; Simmonds, J.; Uauy, C.; Trafford, K. Identification of a major QTL controlling the content of B-type starch granules in Aegilops. J. Exp. Bot. 2011, 62, 2217-2228. [CrossRef] [PubMed]

419. Chia, T.; Adamski, N.M.; Saccomanno, B.; Greenland, A.; Nash, A.; Uauy, C.; Trafford, K.; Lunn, J. Transfer of a starch phenotype from wild wheat to bread wheat by deletion of a locus controlling B-type starch granule content. J. Exp. Bot. 2017. [CrossRef] [PubMed]

420. De Pater, S.; Caspers, M.; Kottenhagen, M.; Meima, H.; Ter Stege, R.; De Vetten, N. Manipulation of starch granule size distribution in potato tubers by modulation of plastid division. Plant Biotechnol. J. 2006, 4, 123-134. [CrossRef] [PubMed]

421. Peng, C.; Wang, Y.; Liu, F.; Ren, Y.; Zhou, K.; Lv, J.; Zheng, M.; Zhao, S.; Zhang, L.; Wang, C.; et al. FLOURY ENDOSPERM6 encodes a CBM48 domain-containing protein involved in compound granule formation and starch synthesis in rice endosperm. Plant J. 2014, 77, 917-930. [CrossRef] [PubMed]

422. Zhang, L.; Ren, Y.; Lu, B.; Yang, C.; Feng, Z.; Liu, Z.; Chen, J.; Ma, W.; Wang, Y.; Yu, X.; et al. FLOURY ENDOSPERM7 encodes a regulator of starch synthesis and amyloplast development essential for peripheral endosperm development in rice. J. Exp. Bot. 2016, 67, 633-647. [CrossRef] [PubMed]

423. Matsushima, R.; Maekawa, M.; Kusano, M.; Kondo, H.; Fujita, N.; Kawagoe, Y.; Sakamoto, W. Amyloplast-Localized SUBSTANDARD STARCH GRAIN4 Protein Influences the Size of Starch Grains in Rice Endosperm. Plant Physiol. 2014, 164, 623-636. [CrossRef] [PubMed]

424. Hebelstrup, K.H.; Sagnelli, D.; Blennow, A. The future of starch bioengineering: GM microorganisms or GM plants? Front. Plant Sci. 2015, 6, 247. [CrossRef] [PubMed] 
(C) 2017 by the authors. Licensee MDPI, Basel, Switzerland. This article is an open access article distributed under the terms and conditions of the Creative Commons Attribution (CC BY) license (http:/ / creativecommons.org/licenses/by/4.0/). 